\title{
Mediterranean intense desert dust outbreaks and their vertical structure based on remote sensing data
}

\author{
Antonis Gkikas ${ }^{1}$, Sara Basart ${ }^{1}$, Nikos Hatzianastassiou ${ }^{2}$, Eleni Marinou ${ }^{3,9}$, Vassilis Amiridis ${ }^{3}$, Stelios Kazadzis ${ }^{4,5}$, \\ Jorge Pey $^{6}$, Xavier Querol ${ }^{7}$, Oriol Jorba ${ }^{1}$, Santiago Gassó ${ }^{8}$, and José Maria Baldasano ${ }^{1,8}$ \\ ${ }^{1}$ Earth Sciences Department, Barcelona Supercomputing Center, Barcelona, Spain \\ ${ }^{2}$ Laboratory of Meteorology, Department of Physics, University of Ioannina, Ioannina, Greece \\ ${ }^{3}$ Institute for Astronomy, Astrophysics, Space Applications and Remote Sensing, National Observatory of Athens, \\ Athens, 15236, Greece \\ ${ }^{4}$ Physikalisch-Meteorologisches Observatorium Davos, World Radiation Center, Switzerland \\ ${ }^{5}$ Institute of Environmental Research and Sustainable Development, National Observatory of Athens, Athens, Greece \\ ${ }^{6}$ Geological Survey of Spain (IGME), Zaragoza, Spain \\ ${ }^{7}$ Institute of Environmental Assessment and Water Research, IDÆA-CSIC C/Jordi Girona, 18-26, 08034 Barcelona, Spain \\ ${ }^{8}$ Environmental Modelling Laboratory, Technical University of Catalonia, Barcelona, Spain \\ ${ }^{9}$ Laboratory of Atmospheric Physics, Department of Physics, Aristotle University of Thessaloniki, Thessaloniki, Greece
}

Correspondence to: Antonis Gkikas (antonis.gkikas@bsc.es)

Received: 20 July 2015 - Published in Atmos. Chem. Phys. Discuss.: 14 October 2015

Revised: 1 April 2016 - Accepted: 28 April 2016 - Published: 15 July 2016

\begin{abstract}
The main aim of the present study is to describe the vertical structure of the intense Mediterranean dust outbreaks, based on the use of satellite and surfacebased retrievals/measurements. Strong and extreme desert dust (DD) episodes are identified at $1^{\circ} \times 1^{\circ}$ spatial resolution, over the period March 2000-February 2013, through the implementation of an updated objective and dynamic algorithm. According to the algorithm, strong DD episodes occurring at a specific place correspond to cases in which the daily aerosol optical depth at $550 \mathrm{~nm}\left(\mathrm{AOD}_{550 \mathrm{~nm}}\right)$ exceeds or equals the long-term mean $\mathrm{AOD}_{550 \mathrm{~nm}}$ (Mean) plus two standard deviations (SD), which is also smaller than Mean $+4 \times \mathrm{SD}$. Extreme DD episodes correspond to cases in which the daily $\mathrm{AOD}_{550 \mathrm{~nm}}$ value equals or exceeds Mean $+4 \times$ SD. For the identification of DD episodes, additional optical properties (Ångström exponent, fine fraction, effective radius and aerosol index) derived by the MODISTerra \& Aqua (also AOD retrievals), OMI-Aura and EPTOMS databases are used as inputs. According to the algorithm using MODIS-Terra data, over the period March 2000February 2013, strong DD episodes occur more frequently (up to 9.9 episodes year ${ }^{-1}$ ) over the western Mediterranean, while the corresponding frequencies for the extreme ones
\end{abstract}

are smaller (up to 3.3 episodes year $^{-1}$, central Mediterranean Sea). In contrast to their frequency, dust episodes are more intense (AODs up to 4.1), over the central and eastern Mediterranean Sea, off the northern African coasts. Slightly lower frequencies and higher intensities are found when the satellite algorithm operates based on MODIS-Aqua retrievals, for the period 2003-2012. The consistency of the algorithm is successfully tested through the application of an alternative methodology for the determination of DD episodes, which produced similar features of the episodes' frequency and intensity, with just slightly higher frequencies and lower intensities. The performance of the satellite algorithm is assessed against surface-based daily data from 109 sun-photometric (AERONET) and $22 \mathrm{PM}_{10}$ stations. The agreement between AERONET and MODIS AOD is satisfactory $(R=0.505-0.750)$ and improves considerably when MODIS level 3 retrievals with higher sub-grid spatial representativeness and homogeneity are considered. Through the comparison against $\mathrm{PM}_{10}$ concentrations, it is found that the presence of dust is justified in all ground stations with success scores ranging from 68 to $97 \%$. However, poor agreement is evident between satellite and ground $\mathrm{PM}_{10}$ observations in the western parts of the Mediterranean, which is 
attributed to the desert dust outbreaks' vertical extension and the high altitude of dust presence. The CALIOP vertical profiles of pure and polluted dust observations and the associated total backscatter coefficient at $532 \mathrm{~nm}\left(\beta_{532 \mathrm{~nm}}\right)$, indicate that dust particles are mainly detected between 0.5 and $6 \mathrm{~km}$, though they can reach $8 \mathrm{~km}$ between the parallels 32 and $38^{\circ} \mathrm{N}$ in warm seasons. An increased number of CALIOP dust records at higher altitudes is observed with increased latitude, northwards to $40^{\circ} \mathrm{N}$, revealing an ascending mode of the dust transport. However, the overall intensity of DD episodes is maximum (up to $0.006 \mathrm{~km}^{-1} \mathrm{sr}^{-1}$ ) below $2 \mathrm{~km}$ and at the southern parts of the study region $\left(30-34^{\circ} \mathrm{N}\right)$. Additionally, the average thickness of dust layers gradually decreases from 4 to $2 \mathrm{~km}$, moving from south to north. In spring, dust layers of moderate-to-high $\beta_{532 \mathrm{~nm}}$ values $\left(\sim 0.004 \mathrm{~km}^{-1} \mathrm{sr}^{-1}\right)$ are detected over the Mediterranean $\left(35-42^{\circ} \mathrm{N}\right)$, extending from 2 to $4 \mathrm{~km}$. Over the western Mediterranean, dust layers are observed between 2 and $6 \mathrm{~km}$, while their base height is decreased down to $0.5 \mathrm{~km}$ for increasing longitudes underlying the role of topography and thermal convection. The vertical profiles of CALIOP $\beta_{532 \mathrm{~nm}}$ confirm the multilayered structure of the Mediterranean desert dust outbreaks on both annual and seasonal bases, with several dust layers of variable geometrical characteristics and intensities. A detailed analysis of the vertical structure of specific DD episodes using CALIOP profiles reveals that the consideration of the dust vertical structure is necessary when attempting comparisons between columnar MODIS AOD retrievals and ground $\mathrm{PM}_{10}$ concentrations.

\section{Introduction}

The Mediterranean Basin, due to its proximity to the major dust source arid areas of northern Africa and the Middle East (Middleton and Goudie, 2001; Prospero et al., 2002; Ginoux et al., 2012) is frequently affected by transported high dust loads referred to as episodes or events. The suspension and accumulation of mineral particles into the atmosphere over the Sahara and Arabian Peninsula's deserts are determined by various factors such as the enhanced turbulence, soil conditions (reduced vegetation cover and soil moisture), reduced precipitation amounts, latitudinal shift of the Intertropical Convergence Zone (ITCZ) as well as by small-scale meteorological processes (e.g. haboobs). However, dust particles can be transported far away from their sources, mainly towards the Atlantic Ocean (e.g. Prospero and Lamb, 2003; Ben-Ami et al., 2010; Huang et al., 2010) and Europe (e.g. Mona et al., 2006, 2012; Papayannis et al., 2008; Basart et al., 2012; Bègue et al., 2012; Pey et al., 2013), favoured by the prevailing atmospheric circulation patterns, from planetary to synoptic scales. Due to their frequent transport in the Mediterranean, mineral dust particles, constitute the predominant aerosol type there (Barnaba and Gobbi, 2004; Basart et al., 2012), as shown by the good agreement, in spatial terms, between the geographical distributions of dust episodes (Gkikas et al., 2013) and average AOD (aerosol optical depths) conditions (Papadimas et al., 2008).

Dust particles play an important role for the shortwave (SW) and longwave (LW) radiation budget (e.g. Kaufman et al., 2002; Tegen, 2003; Heinold et al., 2008; Sicard et al., 2014; Nabat et al., 2015) and climate (IPCC, 2013). They affect atmospheric heating/cooling rates (e.g. Mallet et al., 2009), but they can also result in a modification of atmospheric dynamics and large-scale atmospheric circulations like monsoons (e.g. Lau et al., 2006; Bollasina et al., 2011), cloud properties and precipitation (e.g. Huang et al., 2006; Solmon et al., 2008). Moreover, it has been shown that the consideration of their radiative impacts in numerical simulations can improve the forecasting accuracy of weather models (Pérez et al., 2006). Dust particles also affect air quality in urban areas (Basart et al., 2012) causing adverse health effects (Díaz et al., 2012; Karanasiou et al., 2012; Pérez García-Pando et al., 2014). All these consequences of dust aerosol are relevant and maximize under maximum dust loads, namely dust episodes, thus highlighting the significance of analysing the spatial and temporal characteristics of such events. To this aim, many studies have been carried out using either surface (e.g. Cachorro et al., 2006) or satellite (e.g. Moulin et al., 1998) observations, as well as modelling techniques (e.g. Heinold et al., 2007) focusing on the broader Mediterranean area. These studies were done either for specific dust episodes (e.g. Kubilay et al., 2003; Balis et al., 2006) or for extended periods at specific locations (e.g. Meloni et al., 2007; Toledano et al., 2007a; Gobbi et al., 2013; Mona et al., 2014). Recently, Gkikas et al. (2013) developed an objective and dynamic algorithm relying on satellite retrievals, which enabled an overall view of dust episodes over the entire Mediterranean and the characterization of their regime (i.e., frequency of occurrence, intensity and duration).

Extensive research has also been carried out on the mechanisms of Mediterranean dust outbreaks. Therefore, several mechanisms and processes of transport, apart from dust emissions in source areas, have been proposed as controlling factors. Moulin et al. (1997) showed that the exported dust loads from northern Africa towards the Atlantic Ocean and the Mediterranean are controlled by the phase of the North Atlantic Oscillation (NAO). Other studies, focused on the description of atmospheric circulation characteristics favouring the occurrence of desert dust outbreaks over the central (Barkan et al., 2005; Meloni et al., 2008) or western (Querol et al., 1998; Rodriguez et al., 2001; Salvador et al., 2014) Mediterranean, but on a synoptic scale. An objective classification, based on multivariate statistical methods, of the atmospheric circulation patterns related to dust intrusions over the Mediterranean, has been presented by Varga et al. (2014) and Gkikas et al. (2015). 
The concentration of dust aerosols in the Mediterranean is characterized by strong spatial and temporal variability, associated with the seasonal variability of cyclones dominating or affecting the broader Mediterranean Basin (Trigo et al., 2002). According to Moulin et al. (1998), dust AOD levels are higher in spring and summer compared to the wet seasons of the year. Moreover, dust intrusions are mainly recorded over the southeastern Mediterranean in spring and winter, over the western parts in summer and over the central ones in autumn (Gkikas et al., 2013).

Dust transport over the Mediterranean is characterized by a multi-layered structure (Hamonou et al., 1999; Papayannis et al., 2008) in contrast to the Atlantic Ocean, which is well confined to the Saharan Air Layer (SAL, Karyampudi et al., 1999). The vertical distribution of dust load into the troposphere as well as the profile of dust aerosols' optical properties at different altitudes, control the impacts on atmospheric dynamics induced by the mineral particles (Zhang et al., 2013). In order to describe the geometrical features of dust transport, many researchers have used ground lidar measurements, model simulations (Alpert et al., 2004; Kishcha et al., 2005) or they have relied on a synergistic use of satellite observations and ground lidar profiles (Berthier et al., 2006). The vertical extension of the Saharan dust intrusions over Europe, during the period 2000-2002, was the subject of a comprehensive study by Papayannis et al. (2008), who used lidar measurements from EARLINET (European Aerosol Research Lidar Network, Bösenberg et al., 2003). Over the Mediterranean stations, the mean base, top and thickness of dust layers was found to vary from 1356 to $2980 \mathrm{~m}, 3600$ to $5900 \mathrm{~m}$ and 726 to $3340 \mathrm{~m}$, respectively. According to the obtained results, tracers of dust particles can be detected up to $10 \mathrm{~km}$, as also reported by Gobbi et al. (2000), who studied a Saharan dust event in Crete (southern Greece) during spring of 1999 .

Several similar studies have also been performed for specific Mediterranean locations based on EARLINET lidar measurements. For example, Mona et al. (2006) analysed the vertical structure of 112 Saharan intrusions that occurred over Potenza (Italy), from May 2000 to April 2003. The authors found that these outbreaks are confined between 1.8 and $9 \mathrm{~km}$, while their mass centre is located at $3.5 \mathrm{~km}$ above sea level (a.s.1.). A similar analysis for Athens and Thessaloniki over the period 2000-2002 was conducted by Papayannis et al. (2005), who demonstrated that dust layers are recorded mainly between 2 and $5 \mathrm{~km}$, while their thicknesses vary from 0.2 to $3 \mathrm{~km}$. The geometrical characteristics of dust layers over Athens, during the period 2004-2006, have been also presented by Papayannis et al. (2009), who pointed out that the centre of mass of dust layers is located at $2.9 \mathrm{~km}$ being in a very good agreement with Kalivitis et al. (2007) findings (around $3 \mathrm{~km}$ ) for the eastern Mediterranean. Additionally, the authors reported that the dust layers mainly extend from 1.6 to $5.8 \mathrm{~km}$ while mineral particles can be detected, at very low concentrations, up to $8 \mathrm{~km}$ a.s.l. Gobbi et al. (2013) found that dust plumes over Rome mainly extend from 0 to $6 \mathrm{~km}$, while their centre of mass is located at around $3 \mathrm{~km}$. In the southern parts of Italy (Potenza), dust layers' base is found between 2 and $3 \mathrm{~km}$, their geometrical height extends from 2.5 to $4 \mathrm{~km}$ while tracers of dust particles can be detected up to $10 \mathrm{~km}$, based on a data set of 310 dust events analysed by Mona et al. (2014). Finally, Pisani et al. (2011), based on a statistical analysis of 45 desert dust episodes observed over Naples (Italy), stated that the mean base and top of dust layers are found at $1.5 \mathrm{~km}$ and $4.6 \mathrm{~km}$ a.s.1., respectively, while their mean thickness is equal to $3.1 \mathrm{~km}$, from May 2000 to August 2003.

Surface-based lidar measurements like those used in the aforementioned studies provide useful information about the geometrical and optical properties of dust layers, but they are representative only for specific locations. Yet, more complete knowledge about the vertical structure of dust outbreaks is necessary in order to adequately understand and determine their possible effects. The geographical limitation imposed by the use of surface-based lidar observations can be overcome by utilizing accurate satellite retrievals which provide extended spatial coverage. Since 2006, vertical resolved observations of aerosols and clouds from space were made possible thanks to the CALIOP (Cloud-Aerosol Lidar with Orthogonal Polarization) lidar flying onboard the CALIPSO (Cloud-Aerosol Lidar and Infrared Pathfinder Satellite Observations) satellite (Winker et al., 2009). Based on CALIOP observations, Liu et al. (2008) analysed the global vertical distribution of aerosols for 1 year, while other studies focused on the vertical structure of dust outflows towards the Atlantic Ocean (e.g. Ben-Ami et al., 2009; Adams et al., 2012; Tsamalis et al., 2013) and the Pacific Ocean (e.g. Eguchi et al., 2009; Hara et al., 2009). On the contrary, over the broader Mediterranean area, only a small number of studies have been carried out to describe the vertical distribution of dust aerosols (Amiridis et al., 2013) or specifying the vertical structure of dust events (Amiridis et al., 2009). Nevertheless, they only dealt with a single dust event (1823 May 2008, Amiridis et al., 2009) and thus cannot satisfy the need to know the general vertical structure of Mediterranean dust episodes.

The main target of the present study is to describe the Mediterranean desert dust outbreaks' vertical structure. For this purpose, satellite retrievals derived by the MODISTerra/Aqua, EP-TOMS, OMI-Aura and CALIOP-CALIPSO databases (Sect. 2) are used in a synergistic way. The dust outbreaks are identified with an objective and dynamic algorithm, which uses appropriate aerosol optical properties representative of suspended particles' load, size and nature (Sect. 3). First, the outputs of the satellite algorithm are compared vs. surface measurements provided by AERONET or $\mathrm{PM}_{10}$ stations, located within the study region (Sect. 4.1). Additionally, useful information about various optical and physical properties under intense dust episodes conditions is also derived from the aforementioned analysis. Then, the 
primary characteristics of the intense Mediterranean desert dust (DD) episodes, namely their frequency and intensity, are described in Sect. 4.2. In order to assess the consistency of the algorithm's concept, an alternative methodology for the determination of DD episodes is also applied and the obtained results are inter-compared with the basic methodology. For the identified DD episodes, collocated CALIOPCALIPSO vertical feature mask and total backscatter coefficient at $532 \mathrm{~nm}$ retrievals are used in order to describe the annual and seasonal variability of dust outbreaks' vertical extension over the Mediterranean (Sect. 4.3). Moreover, in Sect. 4.4, a thorough analysis of specific Mediterranean DD episodes is made, in order to examine how the vertical distribution of desert dust outbreaks can affect the agreement between MODIS AOD and $\mathrm{PM}_{10}$ data. Finally, the summary and conclusions are drawn in Sect. 5.

\section{Satellite and surface-based data}

The different types of satellite retrievals that have been used as inputs to the objective and dynamic satellite algorithm are described below, namely the MODIS (Sect. 2.1.1), EP-TOMS and OMI-Aura (Sect. 2.1.2) databases. Also, CALIOP-CALIPSO vertically resolved satellite data, coincident with the identified desert dust outbreaks by the satellite algorithm, are described in Sect. 2.1.3. Finally, surfacebased sun-photometric AERONET retrievals and $\mathrm{PM}_{10}$ concentrations, both used for the comparison against the satellite algorithm's outputs, are described in Sects. 2.2.1 and 2.2.2, respectively.

\subsection{Satellite data}

\subsubsection{MODIS}

MODerate resolution Imaging Spectroradiometer (MODIS) onboard the Terra and Aqua satellites - with daytime local equator crossing time at 10:30 and 13:30 UTC, respectively, and $2330 \mathrm{~km}$ viewing swath - acquires measurements at 36 spectral bands between 0.415 and $14.235 \mu \mathrm{m}$ with varying spatial resolution of 250,500 and $1000 \mathrm{~m}$. Observations from Terra and Aqua are made continuously since February 2000 and July 2002, respectively, and are available from the LAADS website (ftp://ladsweb.nascom.nasa.gov/). Aerosol optical properties are retrieved through the Dark Target (DT) algorithm (see, e.g. Kaufman et al., 1997, 2001; Tanré et al., 1997; Levy et al., 2003; Remer et al., 2005) where different assumptions are considered depending on the underlying surface type (land or ocean). Several evaluation studies (e.g. Remer et al., 2008; Papadimas et al., 2009; Levy et al., 2010; Nabat et al., 2013) have shown that MODIS can satisfactorily retrieve aerosol optical depth (AOD); nevertheless its performance is better over sea (uncertainty equal to $\pm 0.03 \pm 0.05 \times$ AOD; Remer et al., 2002) than over land $( \pm 0.05 \pm 0.15 \times$ AOD; Levy et al., 2010).
The following daily MODIS-Terra and MODIS-Aqua Collection 051 (C051) level 3 satellite data (MOD08_D3 and MYD08_D3 files) provided at $1^{\circ} \times 1^{\circ}$ latitude-longitude spatial resolution are used: (i) $\mathrm{AOD}_{550 \mathrm{~nm}}$, (ii) Ångström ex-

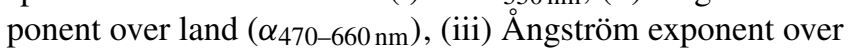
ocean $\left(\alpha_{550-865 \mathrm{~nm}}\right)$, (iv) fine-mode fraction (FF) of AOD over land and ocean and (v) effective radius over ocean ( $\left.r_{\text {eff }}\right)$. It must be mentioned that the size parameters $(\alpha, \mathrm{FF})$ over land are less reliable compared to the corresponding ones over sea, since they are highly sensitive to spectral dependent factors such as errors in the surface model or sensor calibration changes. Over sea, the accuracy of size parameters is strongly dependent on wind conditions.

Similar data have been used by Gkikas et al. (2013). However, in the present study we have improved data quality by using the quality-assurance-weighted (QA) level 3 data (http://modis-atmos.gsfc.nasa.gov/_docs/QA_ Plan_2007_04_12.pdf) derived from the level 2 retrievals $(10 \mathrm{~km} \times 10 \mathrm{~km}$ spatial resolution). Each level 2 retrieval, is flagged with a bit value (from 0 to 3 ) corresponding to confidence levels (no confidence: 0; marginal: 1; good: 2; and very good: 3 ). Based on this, the level $3 \mathrm{QA}$-weighted spatial means are obtained by the corresponding level 2 retrievals considering as weight their confidence level (bit value). In addition, the day cloud fraction as well as the number of level 2 counts, which are both relevant to the performance of the satellite algorithm, are also used in this study. The time series of daily MODIS aerosol data cover the 13 year period March 2000-February 2013 (Terra) and the 10 year period January 2003-December 2012 (Aqua).

\subsubsection{EP/TOMS and OMI-Aura}

The selected retrievals from MODIS provide information about particles' load (AOD) and size ( $\alpha$, FF, $\left.r_{\text {eff }}\right)$, which are both necessary to identify dust episodes. However, since dust is not the only coarse aerosol, for example sea-salt can be so as well, another optical property indicative of particle absorption efficiency is also required by the algorithm. To address this issue, the Aerosol Index (AI) daily data were also used, derived from measurements taken by the Total Ozone Mapping Spectrometer (TOMS) instrument onboard the NASA's Earth Probe satellite (2000-2004) and the Ozone Monitoring Instrument (OMI) onboard the NASA's Aura satellite (20052013). AI is the primary TOMS aerosol product (Herman et al., 1997) based on a spectral contrast method in a UV region $(331-360 \mathrm{~nm})$ where ozone absorption is very small and can be used for the distinction between scattering (e.g. seasalt) and absorbing (e.g. desert dust, smoke) aerosols. The retrieval algorithm (fully described by Torres et al., 1998, $2002,2005)$ takes advantage of the low surface albedo in the UV spectrum range, even in arid and semi-arid areas, making thus possible the estimation of the AOD over highly reflecting desert surfaces, where the major dust sources are located. Since the late 1970s, the TOMS sensor onboard Nimbus-7 
(1978-1993) and Earth Probe (1996-2005) have been providing global aerosol measurements. With the deployment of the EOS-Aura OMI (Ozone Monitoring Instrument) in mid-2004 (Torres et al., 2007) the near UV aerosol record continues to be extended into the foreseeable future. OMI is a hyperspectral sensor, covering the $270-500 \mathrm{~nm}$ range, launched onboard the EOS-Aura satellite on 15 July 2004 (1:38 p.m. equator crossing time, ascending mode) providing almost daily global coverage thanks to its wide viewing swath $(2600 \mathrm{~km}$ with $13 \mathrm{~km} \times 24 \mathrm{~km}$ nadir resolution). Apart from AI measurements, OMI aerosol products include also the total and absorption AOD and the single scattering albedo at 388 and $500 \mathrm{~nm}$ (Torres et al., 2007). Both EP-TOMS and OMI-Aura retrievals are available via the Mirador ftp server (http://mirador.gsfc.nasa.gov/) of the Goddard Earth Sciences Data and Information Services Center (GES DISC). OMI-Aura data, as with MODIS data, are provided at $1^{\circ} \times 1^{\circ}$ spatial resolution, while the EP-TOMS retrievals have been regridded from their raw spatial resolution $\left(1^{\circ} \times 1.25^{\circ}\right)$ in order to match the other two data sets (OMI, MODIS).

\subsubsection{CALIOP-CALIPSO}

The Cloud-Aerosol Lidar with Orthogonal Polarization (CALIOP) onboard the NASA's satellite CALIPSO (Cloud-Aerosol Lidar and Infrared Pathfinder Satellite Observations), launched in April 2006, provides vertical resolved aerosol and cloud observations (Winker et al., 2009) since June 2006. CALIPSO is flying in the A-Train constellation (Stephens et al., 2002; http://atrain.nasa.gov/) in a sun-synchronous polar orbit at $705 \mathrm{~km}$ over the surface, with a 16-day repeat cycle, crossing the equatorial plane at about 13:30 local solar time (Winker et al., 2009). CALIOP is an active sensor measuring the backscatter signal at 532 and $1064 \mathrm{~nm}$ as well as the polarization at $532 \mathrm{~nm}$ (Winker et al., 2009). These level 1 retrievals are further processed (calibration and range corrections) passing to level 2 in order to retrieve the backscatter and extinction coefficients, at 532 and $1064 \mathrm{~nm}$, for aerosol and cloud layers. The identification of cloud and aerosol layers within the atmosphere (Vaughan et al., 2009) is made through the cloud aerosol discrimination (CAD) algorithm (Liu et al., 2009), which is based on the probability distribution functions (PDFs) of altitude-and-latitude-dependent parameters (integrated colour ratio, layer-integrated volume depolarization ratio, mean attenuated backscatter coefficient). CAD scores vary mainly from -100 to 100 indicating the presence of aerosols and clouds when negative and positive, respectively, while bins of confidence levels, both for aerosols and clouds, are defined based on their absolute values (https: //eosweb.larc.nasa.gov/sites/default/files/project/calipso/ quality_summaries/CALIOP_L2VFMProducts_3.01.pdf). More specifically, the performance of the classification scheme in the retrieval algorithm, either for aerosols or clouds, is more reliable for increasing CAD scores in abso- lute terms. Aerosols are categorized in six primary types, namely (i) clean marine, (ii) dust, (iii) polluted continental, (iv) clean continental, (v) polluted dust and (vi) smoke (Omar et al., 2009).

In the present analysis, we use the Version 3 (3.01 and 3.02) of the level 2 Vertical Feature Mask (VFM) and Aerosol Profile Products (APro) files, available from June 2006 to February 2013, both derived from the NASA's Earth Observing System Data and Information System (http://reverb.echo.nasa.gov/). The aerosol profile products are generated at a uniform horizontal resolution of $5 \mathrm{~km}$ (http://www-calipso.larc.nasa.gov/products/ CALIPSO_DPC_Rev3x6.pdf), while the vertical resolution varies from 60 to $180 \mathrm{~m}$ depending on the altitude range and the parameter. The scientific data sets that have been analysed are the following: (i) aerosol subtype, (ii) CAD score and (iii) total backscatter coefficient at $532 \mathrm{~nm}\left(\beta_{532 \mathrm{~nm}}\right)$, reported at several tropospheric and stratospheric levels above mean sea level (Hunt et al., 2009).

\subsection{Surface-based data}

\subsubsection{AERONET}

The AErosol RObotic NETwork (AERONET, Holben et al., 1998) is a worldwide network of installed CIMEL sunsky radiometers obtaining sun-photometric observations in more than 1000 locations of the planet (http://aeronet.gsfc. nasa.gov). The solar irradiances received by the photometer are inverted into columnar aerosol optical and microphysical properties through the implementation of retrieval algorithms (e.g. Dubovik and King, 2000; O’ Neill et al., 2003). The followed standardized methods concerning instrument maintenance, calibration, cloud screening and data processing allow aerosol monitoring and comparison between different study periods and areas (Smirnov et al., 2000). From the global AERONET stations, 109 are located within the geographical limits of our study region. For each station, the daily averages of cloud-screened and quality-assured data (level 2.0) of direct sun and almucantar retrievals are used for the following: (i) AOD at 7 wavelengths from 340 to $1020 \mathrm{~nm}$, (ii) size distribution retrieved for 22 logarithmically equidistant discrete points $\left(r_{i}\right)$ in the range of sizes $0.05 \mu \mathrm{m} \leq r \leq 15 \mu \mathrm{m}$, (iii) Ångström exponent between 440 and $870 \mathrm{~nm}\left(\alpha_{440-870 \mathrm{~nm}}\right)$, (iv) total effective radius $\left(r_{\text {eff }}\right)$ and (v) single scattering albedo (SSA) and asymmetry parameter $\left(g_{\text {aer }}\right)$ both retrieved at $440,675,870$ and $1020 \mathrm{~nm}$. The uncertainty in the estimation of AOD depends on technical (e.g. calibration method) factors and inversion assumptions, both described in detail in Holben et al. (1998). Moreover, the accuracy of the retrieved AOD by the CIMEL radiometer is spectrally dependent, being better $(< \pm 0.01)$ for wavelengths longer than $440 \mathrm{~nm}$ and lower $(< \pm 0.02)$ for the UV wavelengths (Eck et al., 1999). It should be also noted that the AERONET level 2.0 inversion products (e.g. SSA) are 
provided when AOD at $440 \mathrm{~nm}$ is higher than 0.4 ensuring the minimization of the inversion uncertainties, which are also determined by other factors (e.g. scattering angle, particles' sphericity) as stated in detail by Dubovik et al. (2000).

\subsection{2 $\mathbf{P M}_{10}$}

Daily total and dust surface $\mathrm{PM}_{10}$ concentrations, over the period 2001-2011 from 22 regional background and suburban background sites were used in this study. The monitoring sites are distributed as follows: 10 in Spain; 2 in southern France; 5 in Italy; 3 in Greece; 1 in southern Bulgaria and 1 in Cyprus. $\mathrm{PM}_{10}$ concentrations were obtained in most cases from gravimetric determinations on filters, whereas in few cases they were determined by real time instruments (Querol et al., 2009b; Pey et al., 2013) but corrected against gravimetric measurements carried out in annual field campaigns. The disaggregation of the dust component to the total amount is made based on a statistical approach, which has been applied in several past studies (e.g. Rodríguez et al., 2001; Escudero et al., 2007; Querol et al., 2009b; Pey et al., 2013). A full description of the methodology which is followed for the calculation of dust particles' contribution to the total $\mathrm{PM}_{10}$ is presented in Escudero et al. (2007). Briefly, the net dust $\mathrm{PM}_{10}$ amount is calculated through the subtraction of the regional background $\mathrm{PM}_{10}$, which is obtained by applying a monthly moving 30th percentile to the $\mathrm{PM}_{10}$ time series excluding days of dust transport, from the corresponding values of the total $\mathrm{PM}_{10}$ concentrations. Most of the derived data were obtained from the AirBase (http://acm. eionet.europa.eu/databases/airbase/) database, while for the stations Finokalia (Crete) and Montseny (NE Spain) the relevant measurements have been acquired from the EUSAAR (http://www.eusaar.net/) database.

\section{Identification of desert dust episodes}

Following the methodology proposed by Gkikas et al. (2013), desert dust (DD) episodes are identified based on an objective and dynamic algorithm which constitutes a branch of a unified algorithm (Gkikas et al., 2016) able to identify and characterize not only DD episodes, but also four other types of aerosol episodes, namely biomass-urban (BU), dust/sea-salt (DSS), mixed (MX) and undetermined (UN). The algorithm (see Fig. 2 in Gkikas et al., 2013) operates in three steps and is applied in each individual $1^{\circ} \times 1^{\circ}$ geographical cell within the geographical limits of the study domain $\left(29-47^{\circ} \mathrm{N}\right.$ and $\left.11^{\circ} \mathrm{W}-39^{\circ} \mathrm{E}\right)$. First, the mean (Mean) and the associated standard deviation (SD) from the available $\mathrm{AOD}_{550 \mathrm{~nm}}$ retrievals are calculated for the whole study period. These primary statistics are used for the definition of two threshold levels, which are equal to Mean $+2 \times \mathrm{SD}$ and Mean $+4 \times \mathrm{SD}$. The geographical distributions of the computed statistics (Mean and SD) as well as the corresponding spatial patterns of both threshold levels are displayed in Fig. S1a (MODIS-Terra, March 2000February 2013) and S1b (MODIS-Aqua, 2003-2012) in the Supplement. In the next step, the algorithm analyses the daily $\mathrm{AOD}_{550 \mathrm{~nm}}$ time series and classifies an episode as a strong one when AOD is between the two defined thresholds (Mean $+2 \times \mathrm{SD} \leq \mathrm{AOD}_{550 \mathrm{~nm}}<$ Mean $+4 \times \mathrm{SD}$ ) and as an extreme one when AOD is higher/equal than Mean $+4 \times \mathrm{SD}$. The same approach was undertaken by Gkikas et al. (2009) who classified the Mediterranean aerosol episodes over the period 2000-2007 according to their strength and described their frequency and intensity. It must be clarified that according to our methodology in areas frequently affected by dust episodes, both mean and standard deviation values are expected to be high, resulting in high thresholds, which means that cases with moderate-to-high AODs - also possibly relevant to radiative and health effects - are masked out from the data set. In order to investigate the possible impact of this, "unbiased" mean, standard deviation and thresholds of AOD are also computed based on another methodology and the results are discussed comparatively to those of the primary methodology in a separate paragraph (Sect. 4.2). Moreover, it must be mentioned that the satellite algorithm identifies only intense desert dust episodes since their AOD must be higher than Mean $+2 \times \mathrm{SD}$ which is considered as a high threshold level.

It should be noted that the representativeness of the calculated mean levels is possibly affected by the availability of the AOD retrievals and particularly by the way these data are distributed both at temporal and spatial scales. Thus, a possible underrepresentation of winter AOD data in the long-term data set, which is often the case in satellite retrievals of AOD, may result in a higher mean AOD than what would be present if seasonal availability was complete and balanced. Moreover, the spatiotemporal availability of AOD is determined by the different satellite retrieval algorithm assumptions depending on the underlying surface type (land or sea) and clouds (i.e. satellite retrievals are possible only under clearsky conditions). In order to investigate the possible effect of temporal availability of daily AOD data, we have calculated the percentage availability of AOD retrievals on a monthly, seasonal and year-by-year basis, over the period 2000-2013 (results not shown here). Seasonal differences of AOD availability are mainly encountered in the northernmost parts of the study region, attributed to the enhanced cloud coverage, with lower values (20 to $40 \%$ ) from December to February against $50-85 \%$ for the rest of the year. Differences in AOD availability, which are more pronounced in winter and summer and less remarkable during the transition seasons, are also found between land and sea surfaces. More specifically, across the Mediterranean Sea, in winter, the availability percentages range from 70 to $90 \%$ while in summer the corresponding values are decreased, due to Sun glint, down to 60 and $80 \%$, respectively. Over land, for both seasons, the spatial patterns of AOD availability are reversed. In order to fur- 
thermore investigate how the spatiotemporal AOD variability and unbalanced seasonal distribution of MODIS AOD data can affect the calculated mean AOD levels (calculated by daily retrievals), we have repeated the calculations by utilizing monthly retrievals (calculated from the daily ones) thus removing the possible effects of an unequal temporal distribution of the number of observations on the mean AOD. According to our results, only small differences are found, generally hardly exceeding 0.1 in absolute and $5 \%$ in relative percentage terms, with the mean AODs over land being higher when they are computed from daily rather than monthly data, while the opposite is found over sea. This finding reveals that the unequal temporal distribution of AOD retrievals does not have a critical impact on the computed mean AODs or on the resulting algorithm outputs presented in this study.

In a further step of the methodology, the strong and extreme DD episodes are identified separately over land and sea surfaces of the study region. This is achieved through the use of specific aerosol optical properties, namely the Angström exponent, effective radius, fine fraction and aerosol index, which provide information about particles' size and nature. For each optical property, appropriate upper or lower thresholds have been set up which must be valid concurrently in order to certify the presence of dust particles in the atmosphere. Note that there are not any unanimously defined acknowledged thresholds in literature. Therefore, these cut-off levels have been selected here according to the literature findings, availability of raw data and several original sensitivity tests (more details are provided in Gkikas et al., 2013), which have been applied individually to the MODIS size parameters (i.e., $\alpha$, FF and $r_{\text {eff }}$ ). Such an analysis is essential when multiparameter data sets are utilized and their variations can possibly modify the satellite algorithm's outputs. To this aim, we have applied the satellite algorithm modifying by 0.1 the $\alpha$,

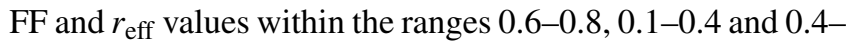
0.8 , respectively. Our results indicate that the geographical patterns remain similar, and the total number of DD episodes is only slightly modified (less than $4 \%$ ) for the $\alpha$ and $r_{\text {eff }}$ retrievals, whereas it changes more for the FF retrievals (by up to $25 \%$ over sea for strong episodes). Here, the validity of these thresholds is further evaluated against AERONET measurements and the corresponding results are discussed in Sect. "Intercomparison of surface-based and satellite algorithms used for the identification of the desert dust episodes".

In order to address the issue of possible overestimation of the defined threshold levels, particularly in the most dust-affected areas mentioned above, we have also applied the satellite algorithm using an alternative methodology (METHOD-B) in which dust-affected grid cells were excluded. In this case, from the raw AOD retrievals we have masked out the "pure" desert dust grid cells, which were identified based on the concurrent fulfillment of the defined criteria for dust occurrence in the algorithm (for Ångström exponent, fine fraction, aerosol index and effective radius).
Then, from the remaining data (non-dust AOD retrievals), the mean, the associated standard deviation as well as the defined thresholds of AOD are computed for the whole study period, for each pixel, as also done in the primary methodology. Finally, also similarly to the way done in the primary methodology, the DD episodes were classified into strong and extreme ones. The obtained results, i.e. frequency of occurrence and intensity of DD episodes, based on the primary methodology and METHOD-B are discussed in Sect. 4.2.

As explained, a similar methodology and data were used in the study by Gkikas et al. (2013). Nevertheless, the present one is a significant extension mainly for five reasons: (i) DD episodes are identified here over an extended period of study and for both MODIS platforms, i.e. March 2000-February 2013 for MODIS-Terra and 2003-2012 for MODIS-Aqua, (ii) a second methodology (METHOD-B) for the identification of DD episodes is tested, (iii) the quality of the input data is improved by using QAweighted level-3 data produced by weighting level-2 data based on their confidence flag, (iv) emphasis is given to the vertical structure of the intense DD episodes and $(v)$ the role of the detailed dust outbreaks' vertical structure for the level of agreement between columnar MODIS AOD and ground $\mathrm{PM}_{10}$ concentrations is investigated. In addition, in the present analysis, the satellite algorithm is also tested using only AODs associated with cloud fractions (CFs) lower/equal than 0.8 , in order to investigate possible modifications of our results due to the cloud contamination effects on MODIS AODs. The critical value of 0.8 for CFs has been defined according to Zhang et al. (2005) and Remer et al. (2008), who stated that under extended cloud-coverage conditions AOD levels can be increased substantially.

\section{Results}

Before dealing with the horizontal patterns (Sect. 4.2) and the vertical structure of dust outbreaks (Sects. 4.3 and 4.4), it is very important to compare the algorithm's outputs against AERONET and $\mathrm{PM}_{10}$ observations (Sect. 4.1) in order to ensure an accurate three-dimensional view of the intense Mediterranean DD episodes. It must be clarified that the comparison of the satellite algorithm's outputs vs. AERONET/PM 10 is made only for its default version and not for the METHOD-B, since there are no remarkable differences between the two methodologies, as it will be presented in Sect. 4.2. For the same reason, the synergistic implementation of the CALIOP-CALIPSO lidar profiles is done only when the DD episodes are identified based on the primary methodology. The present section has been organized accordingly, and the results are given below. 


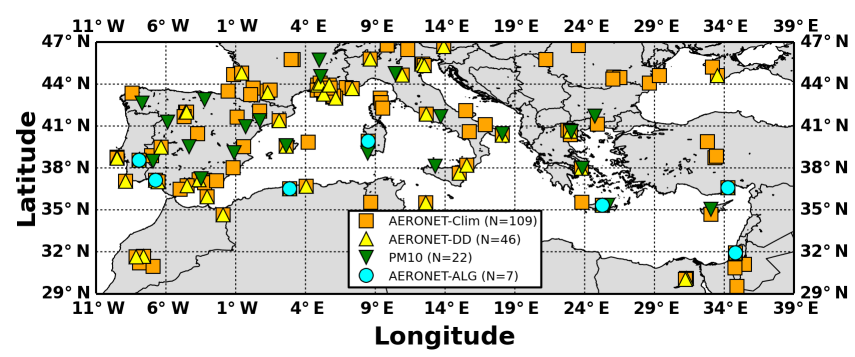

Figure 1. Locations of the AERONET and $\mathrm{PM}_{10}$ stations that have been used for the evaluation of the algorithm's outputs. More specifically, orange squares denote the AERONET stations located into the study region, with the yellow triangles, the AERONET stations with coincident satellite and ground retrievals under dust episodes conditions, with the cyan circles, the AERONET stations which have been used for the evaluation of the defined algorithm thresholds, and with the green triangles are depicted the $\mathrm{PM}_{10}$ stations.

\subsection{Comparison of the satellite algorithm's outputs against AERONET and $\mathrm{PM}_{10}$ measurements}

The ability of the satellite algorithm to identify satisfactorily DD episodes, is tested against ground measurements from 109 AERONET (Fig. 1, orange squares) and 22 PM $_{10}$ (Fig. 1, green triangles) stations located in the broader Mediterranean area. This is an extended and thorough comparison which largely exceeds a similar one done for the outputs of the previous version of the satellite algorithm (2000-2007; Gkikas et al., 2013), but only relying on nine AERONET stations and using AOD and volume size distribution data. Here, the comparison is repeated for the improved algorithm, being extended over a longer time period, for a much larger number of AERONET stations, and an analysis of more optical properties, namely the Ångström exponent, effective radius, single scattering albedo and asymmetry parameter is made. The comparison is performed for both study periods and satellite platforms (March 2000-February 2013 for Terra and 20032012 for Aqua), but the issue of possible cloud contamination is also considered. However, since the obtained results revealed a very similar performance of the algorithm for both periods and platforms, only the results for the period March 2000-February 2013 are given here.

In 46 out of 109 AERONET stations, depicted with yellow triangles in Fig. 1, we have found at least one strong or extreme dust episode, for which coincident satellite and ground measurements are available. For the specific AERONET stations and episode days, the mean values of the selected AERONET aerosol optical properties have been calculated separately for strong, extreme and all (both strong and extreme) DD episodes identified by the satellite algorithm. Subsequently, these values were compared to the corresponding ones calculated from all the available retrievals (climatological conditions, clim) collected from the 109 Mediterranean AERONET stations, during the period
March 2000-February 2013, aiming at highlighting the effect of episodes on these optical properties. Additionally, in seven AERONET stations (cyan circles in Fig. 1) the intense DD episodes have been identified from ground (AERONET) and the corresponding results are compared with the satellite algorithm outputs (Sect. "Intercomparison of surfacebased and satellite algorithms used for the identification of the desert dust episodes"). Finally, the performance of the algorithm is also tested against surface $\mathrm{PM}_{10}$ measurements from 22 stations (Sect. 4.1.2).

\subsubsection{AERONET}

\section{Aerosol optical depth}

During the period March 2000-February 2013, 346 pixellevel intense DD episodes have been identified by the satellite-based algorithm, in which coincident MODIS-Terra and AERONET retrievals are available. The selected data set corresponds to $1.06 \%$ of the overall (strong and extreme) DD episodes ( 32635 ), which have been identified during the study period. It should be noted that AERONET AOD $550 \mathrm{~nm}$ values have been calculated from available AERONET $\mathrm{AOD}_{870 \mathrm{~nm}}$ and Ångström exponent data $\left(\alpha_{440-870 \mathrm{~nm}}\right)$ by applying the Ångström equation (Ångström, 1929) to match the MODIS AOD ${ }_{550 \mathrm{~nm}}$. For these intense DD episodes, the comparison between the satellite and ground aerosol optical depths at $550 \mathrm{~nm}$ is given in Fig. 2. Two similar scatter plots with matched MODIS-AERONET data pairs are given. The first one (Fig. 2i-a) is resolved by the number of level 2 (L2) measurements of $10 \mathrm{~km} \times 10 \mathrm{~km}$ spatial resolution from which the compared $1^{\circ} \times 1^{\circ}$ level 3 (L3) AODs in the figure are derived. The second scatter plot (Fig. 2i-b) is resolved by the spatial standard deviation inside the $1^{\circ} \times 1^{\circ}$ geographical cell (level 3 AODs). Both scatter plots address the issue of level 3 AOD sub-grid spatial variability, which is essential when attempting comparisons against local surface-based AOD data like the AERONET.

The overall correlation coefficient $(R)$ between MODIS and AERONET AODs is equal to 0.505, with the satellite AODs being overestimated (bias $=0.143$ ). The scatter plots show the existence of outliers associated with a small number of level 2 retrievals $(<20$, blue colour Fig. 2i-a) and/or high standard deviations ( $>0.5$, yellowish-reddish points, Fig. $2 \mathrm{i}-$ b) inside the L3 grid cell. This finding underlines the role of homogeneity and representativeness of L3 retrievals for the comparison of MODIS AODs against AERONET. This role is better visualized in Fig. 2ii-a, where the computed $R$ values between MODIS level-3 and AERONET AODs, depending on the number of L2 retrievals from which the L3 products were derived, are presented. In general, it is known that the L2 pixel counts range from 0 to 121 , while in polar regions (typically around $82^{\circ}$ latitude) the maximum count numbers can be even higher due to overlapping orbits and near nadir views intersect (Hubanks et al., 2008). It is clear 


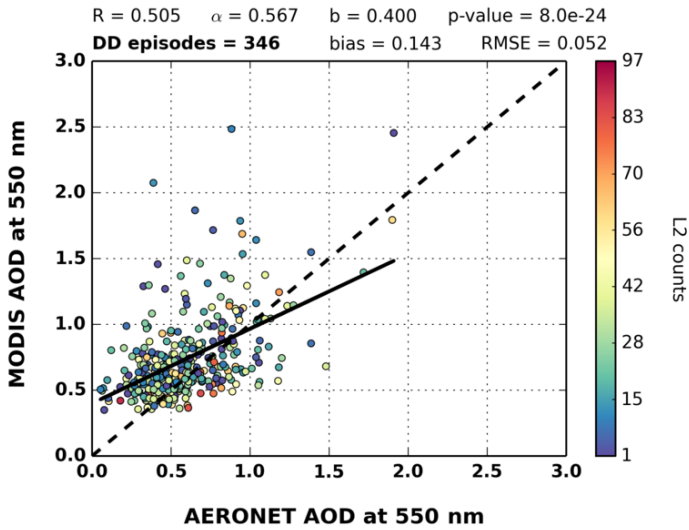

(i-a)

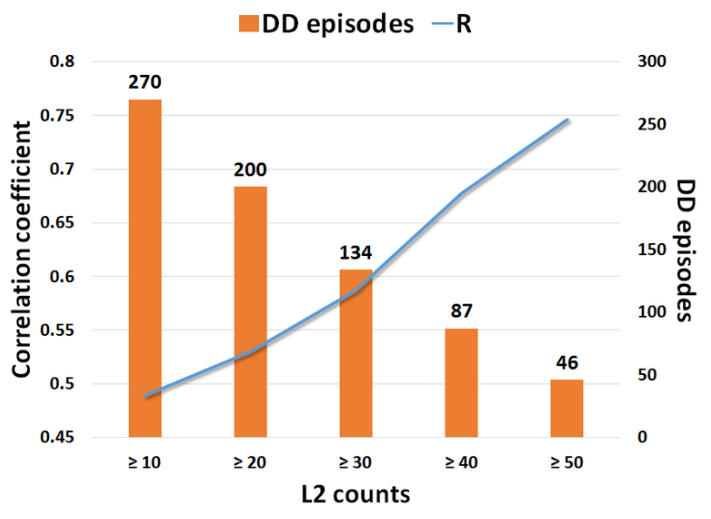

(ii-a)

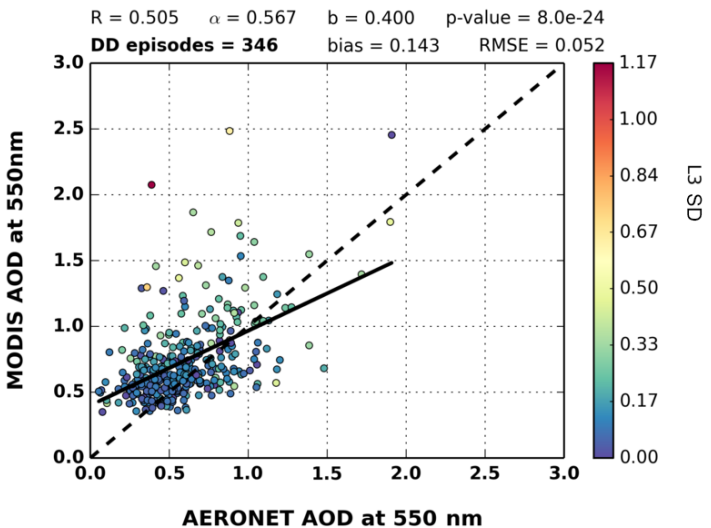

(i-b)

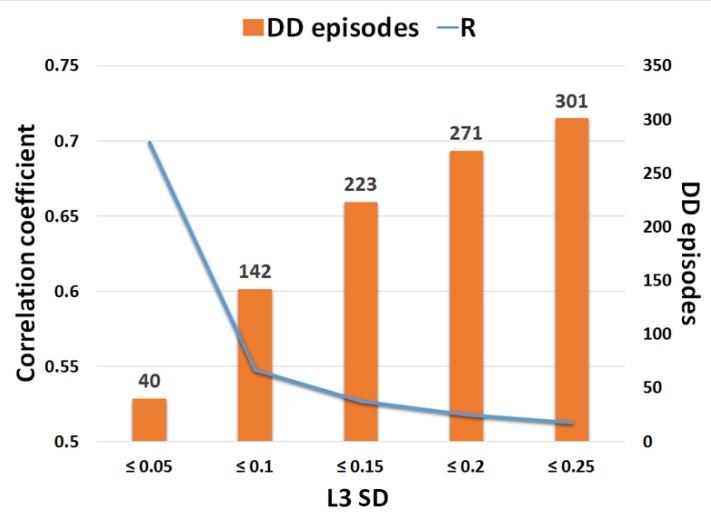

(ii-b)

Figure 2. (i) Scatterplots between MODIS-Terra and AERONET aerosol optical depths at $550 \mathrm{~nm}$ under intense desert dust episodes conditions related to the (-a) number of level-2 counts which are used for the calculation of the level-3 retrievals and (-b) spatial standard deviation inside the $1^{\circ} \times 1^{\circ}$ grid cells (level-3 retrievals). (ii) Sensitivity analysis for the calculated correlation coefficients between satellite and ground AODs, depending on the (-a) number of level-2 retrievals and (-b) sub-grid standard deviation of level-3 retrievals.

from our results that the correlation coefficients are gradually and essentially improved, from 0.49 to 0.75 , with increasing representativeness of MODIS AODs, i.e. increasing counts of L2 retrievals attributed. A similar improvement has been reported by Amiridis et al. (2013) who found a better agreement between MODIS/AERONET and CALIOP aerosol optical depths applying similar criteria. The agreement between MODIS and AERONET also improves when the former AOD products are more spatially homogeneous, i.e. when they are characterized by smaller AOD standard deviations at the grid-level (from $<0.25$ down to $<0.05$, Fig. 2ii-b). However, our results also indicate that apart from increasing correlation coefficients (up to 0.7-0.8) with increasing level-2 counts and decreasing standard deviations, the number of intense DD episodes is decreased dramatically (to about 40-50 for more than 50 counts and standard deviation to smaller than 0.05 ).

In order to assess the performance of the satellite algorithm when operated with non-weighted (Gkikas et al., 2013) and weighted QA (present analysis) MODIS-Terra retrievals we have compared its outputs (DD episodes' AODs) of both versions vs. the corresponding AERONET AODs for the period March 2000-February 2007 (Gkikas et al., 2013). Based on our results, the computed correlation coefficients are equal to 0.53 (135 DD episodes) and 0.59 (177 DD episodes) for the old and new version of the satellite algorithm, respectively, revealing thus a better performance when QAweighted level 3 retrievals are utilized as inputs to the satellite algorithm.

Finally, the spectral variation of the AERONET AODs at seven wavelengths (from 340 to $1020 \mathrm{~nm}$ ) in climatological and dust episodes conditions has been investigated (results given in Fig. S2, Supplement). The AOD box plots produced for all the available daily AERONET measurements (orange) and for the corresponding retrievals during strong (cyan), extreme (red) and all DD (green) episodes identified by the satellite algorithm show that the spectral variation of aerosol optical depth decreases in cases of dust episodes, with respect to the "climatological" conditions. This is mainly attributed 


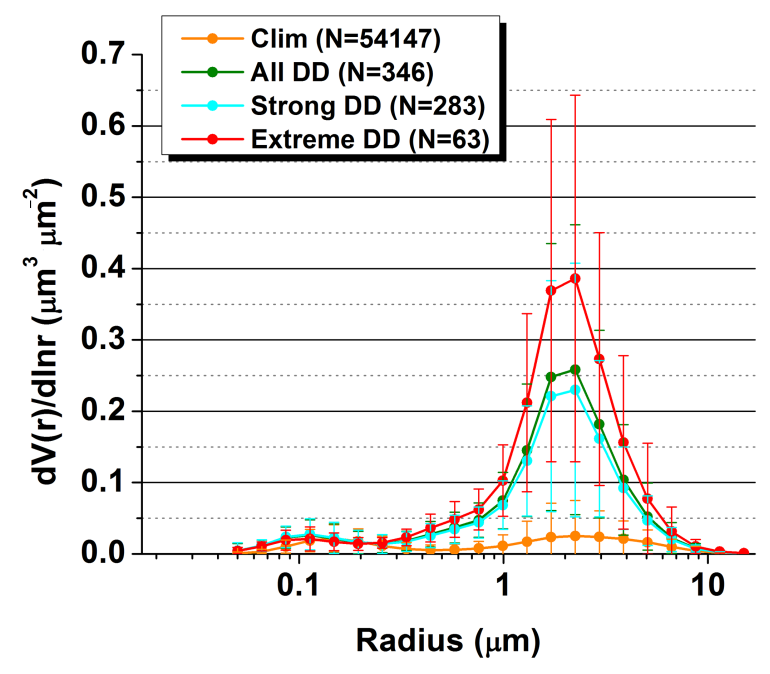

Figure 3. AERONET size distributions averaged over all available retrievals (orange curve) as well as over the total (green curve), strong (cyan curve) and extreme (red curve) desert dust episodes that occurred over the broader area of the Mediterranean Basin, during the period March 2000-February 2013. The error bars represent the calculated standard deviations.

to the further increasing AOD levels at wavelengths longer than $500 \mathrm{~nm}$ (by about 6 times) than in (or near) the visible.

\section{Aerosol volume size distribution}

Fig. 3 presents the mean aerosol volume size distributions (AVSDs) calculated from all available AERONET data (orange curve) as well as under strong (cyan curve), extreme (red curve) and all (green curve) DD episodes conditions. The results are given for March 2000-February 2013 using MODIS-Terra (346 intense DD episodes) retrievals as inputs to the satellite algorithm. In the climatological curve, two modes are distinctly centred at $0.15 \mu \mathrm{m}$ for the fine mode and $2.24 \mu \mathrm{m}$ for the coarse mode. There is an about equal contribution of both modes, indicating the coexistence of fine (e.g. urban aerosols) and coarse (e.g. dust aerosols) particles over the broader Mediterranean area. This result is in agreement with previous studies for the Mediterranean (e.g. Fotiadi et al., 2006; Mallet et al., 2013). However, under dust episodes conditions, although the AVSD still has two modes, there is a dramatic increase of the coarse mode, which strongly dominates. More specifically, the peak of the coarse mode (radius between 1.7 and $2.24 \mu \mathrm{m}$ ) is increased by factors of about 10 , 15 and 11 for the strong, extreme and all DD episodes. The differences between the strong and extreme AVSDs are statistically significant (confidence level at $95 \%$ ) for almost all size bins (18 out of 22) except bin $1(0.050 \mu \mathrm{m}), 2(0.065 \mu \mathrm{m})$, $6(0.194 \mu \mathrm{m})$ and $7(0.255 \mu \mathrm{m})$. Moreover, it should be noted that the increment factors are slightly decreased when the algorithm operates only with AOD retrievals associated with cloud fractions less than 0.8 , which is reasonable since possi- ble "overestimated" retrievals are masked out from the analysis. Similar modifications in the shape of AVSD during dust outbreaks have been pointed out by several studies in the past, either for the Mediterranean region (e.g. Kubilay et al., 2003; Lyamani et al., 2005; Córdoba-Jabonero et al., 2011) or for other dust affected areas of the planet (e.g. Alam et al., 2014; Cao et al., 2014).

\section{Size optical properties, single scattering albedo and asymmetry parameter}

The accuracy of the DD episodes identification method was further assessed by also using other AERONET aerosol optical properties than AOD, namely the Ångström exponent $(\alpha)$ and the effective radius $\left(r_{\text {eff }}\right)$, which are able to provide information about particles' size. For both aerosol optical properties, the box plots for all the available AERONET retrievals as well as for the corresponding data during strong, extreme and all DD episodes, have been produced and depicted in Fig. S3 (Supplement).

Based on our results, the appropriateness of the applied methodology is confirmed by the drastic reduction of $\alpha$ and increase of $r_{\text {eff }}$ values when dust outbreaks occur. When all available AERONET retrievals are considered (clim), the majority ( $>75 \%$ ) of $\alpha$ values is higher than 1.04, indicating the strong presence of fine particles in the study domain (Fig. S3i). On the contrary, during intense dust episodes the majority of the corresponding values for all, and strong DD episodes are lower than 0.54 , while for the extreme ones said values are lower than 0.36 . Such low Ångström exponent values, attributed to transported mineral particles from the northern African deserts (Pace et al., 2006), have been reported also in previous studies (e.g. Tafuro et al., 2006; Basart et al., 2009). The existence of coarse aerosols is also confirmed by the increase of $r_{\text {eff }}$ values under intense DD conditions compared to the climatological levels (Fig. S3ii). For all DD episodes, the $75 \%$ of $r_{\text {eff }}$ values is higher than $0.55 \mu \mathrm{m}$ reaching up to $1.4 \mu \mathrm{m}$, while the mean and the median values are equal to about 0.73 , compared to about 0.37 for the climatological conditions. These values are even higher when extreme DD episodes are concerned.

Moreover, the spectral variations of the averaged AERONET single scattering albedo (SSA) and the asymmetry parameter $\left(g_{\text {aer }}\right)$ are also studied. During intense dust outbreaks the shape and magnitude of spectral SSA (Fig. S4i) and $g_{\text {aer }}$ (Fig. S4ii) are modified compared to the climatological conditions. The spectral curves of both parameters become less and more flattened during dust episodes for SSA and $g_{\text {aer }}$, respectively. For SSA, the steepening results from decreasing values in the visible and increasing values in the near-infrared (by up to 0.04 , reaching 0.97 at $1020 \mathrm{~nm}$ ). The flattening for $g_{\text {aer }}$ arises from smaller and larger increments in visible and near-infrared wavelengths, by up to 0.04 and 0.09 , respectively. The differences between strong and extreme DD episodes SSA spectral curves are statistically sig- 
nificant at $95 \%$ confidence level only at 870 and $1020 \mathrm{~nm}$. On the contrary, the corresponding differences for the $g_{\text {aer }}$ are statistically significant in all wavelengths. Our results are in agreement with those presented for SSA by Mallet et al. (2013) in the Mediterranean and for $g_{\text {aer }}$ by AladosArboledas et al. (2008) during a dust episode over the southeastern parts of Spain.

\section{Intercomparison of surface-based and satellite algorithms used for the identification of the desert dust episodes}

Despite their great usefulness, satellite aerosol retrievals still suffer from uncertainties, and generally are considered as inferior to surface-based similar products, which are taken as the reference. In order to examine this degree of uncertainty and to verify the successful performance of the algorithm, we also tested using it along with AERONET retrievals. This has been made for seven Mediterranean AERONET stations, depicted with cyan circles in Fig. 1, during the periods for which ground retrievals are available (Table 1). The selection of the AERONET stations was based on (i) data availability (see last column of Table 1), (ii) their location (i.e. near the northern African and Middle East deserts) and (iii) the inclusion of sites where the aerosols' regime is complex (e.g. El Arenosillo, FORTH Crete). The intense DD episodes were identified following the methodology described in Sect. 3, but using only AOD at $870 \mathrm{~nm}, \alpha_{440-870 \mathrm{~nm}}$ (lower/equal than 0.7 ) and $r_{\text {eff }}$ (higher than 0.6) as criteria, based upon their availability from AERONET. Subsequently, the algorithm was also operated again using satellite (MODIS-Terra, OMIAura, EP-TOMS) input data for the periods with available retrievals in each of the 7 AERONET stations.

In Fig. 4, we present the overall scatter plots between satellite and ground AODs when intense DD episodes have been identified based on the ground (left column) and the satellite (right column) algorithm. Colours in Fig. 4i-a, ii-a, iii-a represent the associated MODIS-Terra Ångström exponent, effective radius and day cloud fraction retrievals, respectively. In Fig. 4i-b and ii-b colours represent the AERONET Ångström exponent and effective radius, respectively, while in Fig. 4iii-b they represent the day cloud fraction observations derived by MODIS-Terra. Through this approach it is feasible to further assess the performance of the satellite algorithm, specify its drawbacks and check the validity of the defined thresholds (green boxes in Fig. 2 in Gkikas et al., 2013).

It is apparent that the agreement between MODIS-Terra and AERONET AODs is better when DD episodes are identified from the ground, as shown by the increased correlation coefficients (from 0.521 to 0.704 ), increased slopes (from 0.6 to $0.9-1.0$ ) and decreased biases (from 0.16 to -0.03). In particular, when DD episodes are identified from space, the MODIS-Terra AOD retrievals are overestimated (bias $=0.163$ ) with regards to AERONET, particularly at low
AOD values $(<0.5)$. In both algorithms, the highest overestimations are associated with cloud fractions higher than 0.7 due to the possible contamination of the satellite AODs by clouds (Fig. 4iii-a, iii-b). Given that DD episodes' identification based on AERONET retrievals is more efficient, we have used these results in order to check the validity of the defined thresholds for $\alpha$, AI, FF and $r_{\text {eff }}$ used in the satellite algorithm. For each aerosol optical property, we have calculated the percentage of intense DD episodes for which the corresponding satellite observations are below or above the defined thresholds, depending on the parameter. The results given in Table 2 are satisfactory, since the percentages range from 87 to $99 \%$, and they confirm the validity of the defined thresholds.

The scatter plots in Fig. 4i-b and ii-b also reveal some weaknesses of the satellite-based algorithm. More specifically, it is found that for few DD episodes identified by the satellite algorithm the corresponding AERONET Ångström exponent and effective radius values are higher than 1 and smaller than 0.4 , respectively. These values indicate a predominance of fine particles instead of coarse ones, as would be expected for desert dust aerosols. In order to quantify the number of misclassified pixel level intense DD episodes by the satellite algorithm, we have computed the percentage of cases for which the AERONET $\alpha$ values are higher than 1 $(15 \%)$ and $r_{\text {eff }}$ values are lower than $0.4(17.7 \%)$. Also, we have repeated these calculations for all DD episodes (Sect "Aerosol optical depth") and the corresponding percentages were found to be equal to 11.8 and $14.5 \%$, respectively. These misclassifications of the satellite algorithm occur in AERONET stations (e.g. Thessaloniki, Rome, Avignon) with a strong presence of anthropogenic aerosols (Kazadzis et al., 2007; Gobbi et al., 2007; Querol et al., 2009a; Yoon et al., 2012). Some misclassifications also occur in AERONET stations (e.g. Evora, El Arenosillo, FORTH CRETE) with mixed (natural plus anthropogenic) aerosol loads (Fotiadi et al., 2006; Toledano et al., 2007b; Hatzianastassiou et al., 2009; Pereira et al., 2011). Over these areas, there are converging air masses carrying particles of different origin, as shown by performed back-trajectories analyses (results are not shown here) using the HYSPLIT (Hybrid SingleParticle Lagrangian Integrated Trajectory) model (Draxler and Rolph, 2015). Nevertheless, it must be mentioned that DD episodes' misclassifications can also be attributed to the lower accuracy of MODIS aerosol size retrievals over land (Sect. 2.1.1).

\subsection{2 $\mathrm{PM}_{10}$ and dust contribution}

The satellite algorithm's outputs, apart from AERONET retrievals, have been also compared against ground $\mathrm{PM}_{10}$ concentrations $\left(\mu \mathrm{g} \mathrm{m}^{-3}\right)$ measured in 22 Mediterranean stations (green triangles in Fig. 1).

First, for each station, the number of intense DD episodes was calculated, for which coincident satellite and ground 


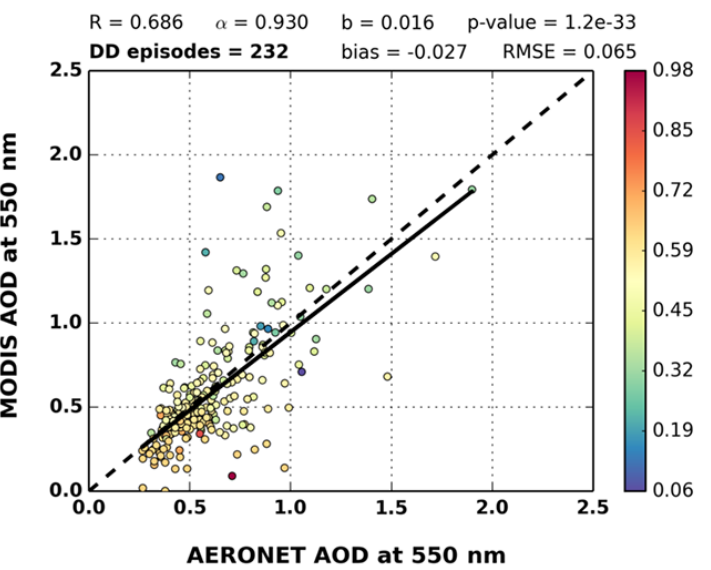

(i-a)

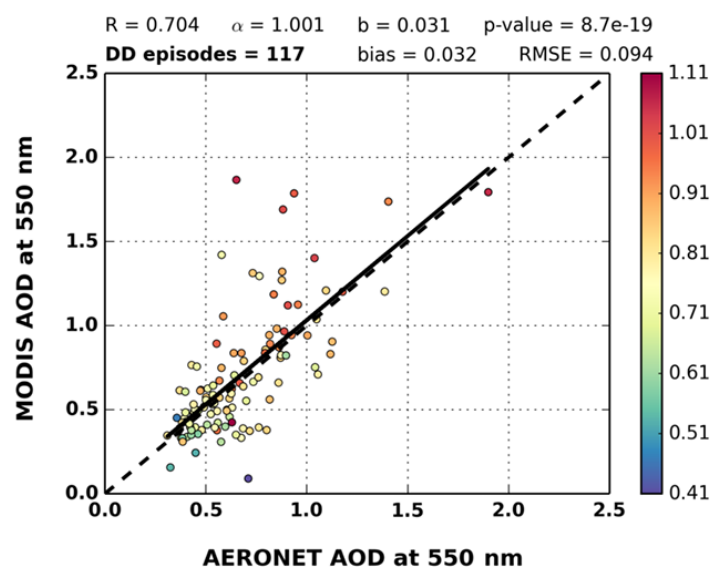

(ii-a)

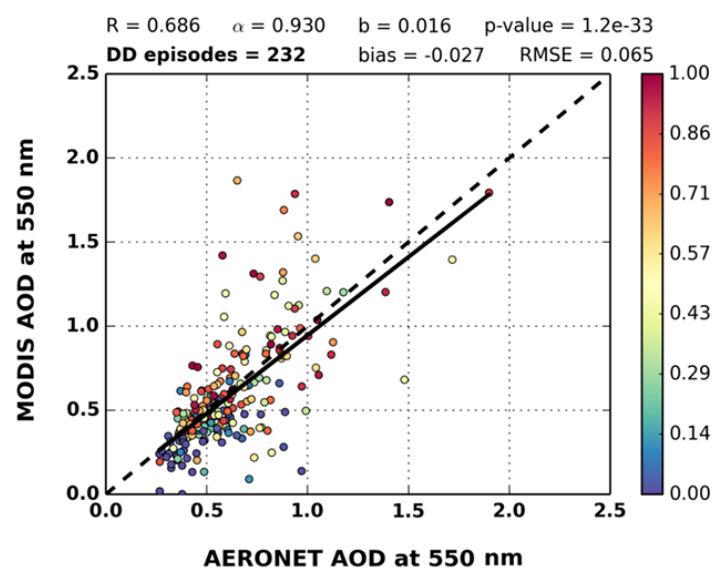

(iii-a)

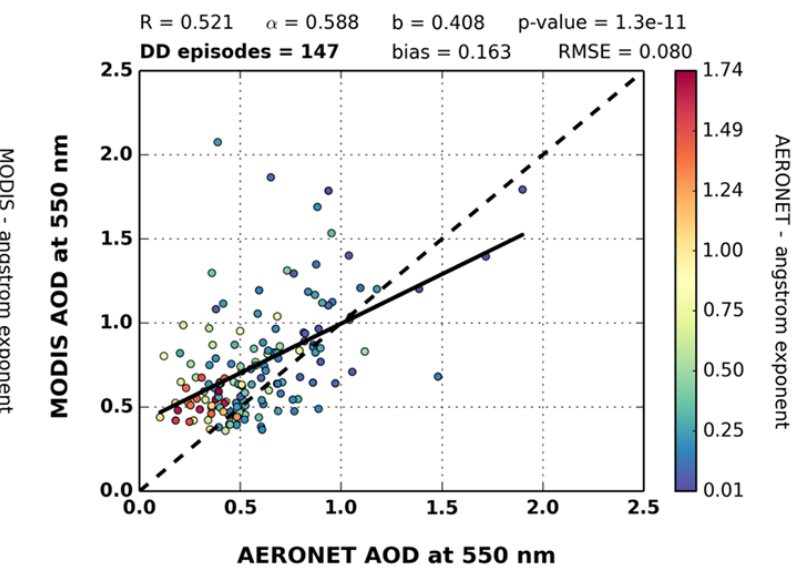

(i-b)

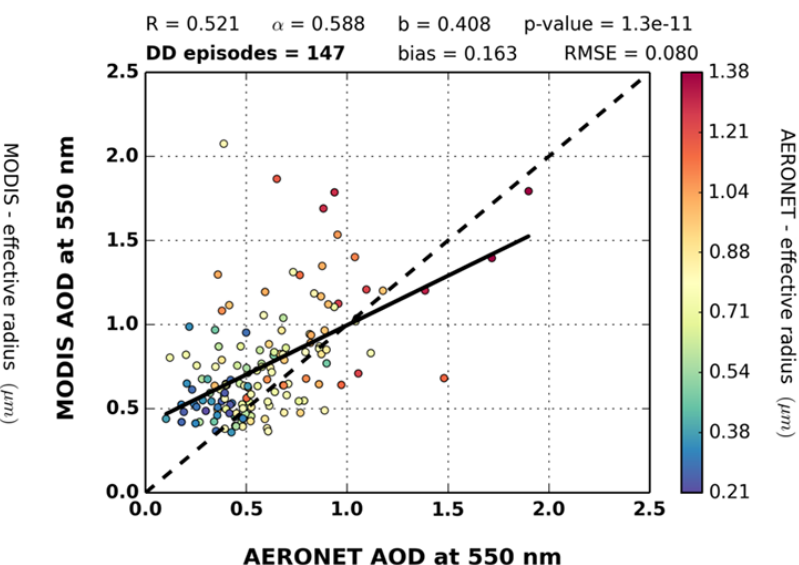

(ii-b)

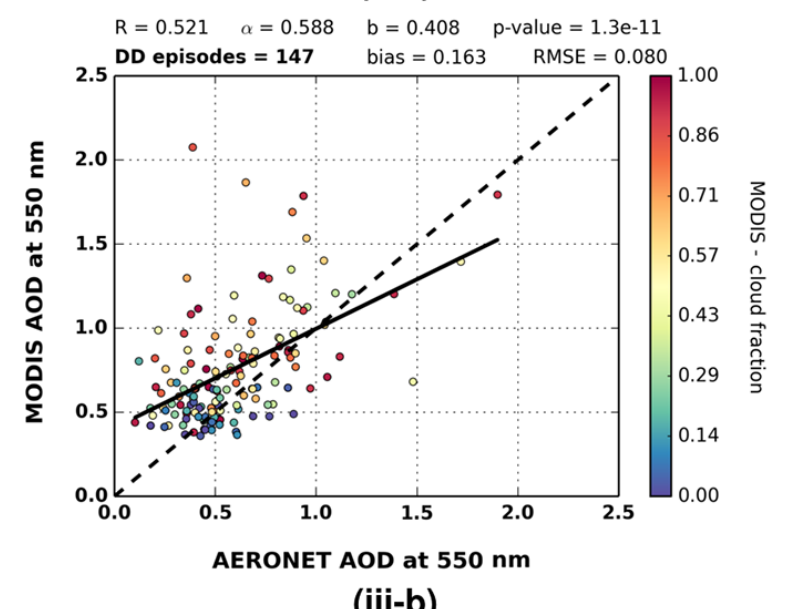

(iii-b)

Figure 4. Scatter plots of MODIS-Terra and AERONET aerosol optical depths at $550 \mathrm{~nm}$ when intense dust episodes have been identified based on (a) AERONET retrievals and (b) satellite algorithm, respectively. In the left column, colour maps indicate the corresponding values of (i) Ångström exponent, (ii) effective radius and (iii) day cloud fraction derived by MODIS-Terra retrievals. In the right column, colour maps indicate the corresponding values of (i) AERONET Ångström exponent, (ii) AERONET Effective radius and (iii) MODIS day cloud fraction retrievals. For each scatter plot, the correlation coefficient $(R)$, slope $(\alpha)$, intercept $(b), p$ value, number of DD episodes, bias (MODIS - AERONET) and root mean square error (RMSE) are provided. 
Table 1. AERONET stations, depicted with cyan colours in Fig. 1, used for the identification of desert dust (DD) episodes based on ground retrievals.

\begin{tabular}{|c|c|c|c|}
\hline Stations & Latitude & Longitude & Study period \\
\hline Blida & $\mathrm{N} 36^{\circ} 30^{\prime} 28^{\prime \prime}$ & $\mathrm{E} 02^{\circ} 52^{\prime} 51^{\prime \prime}$ & 7 Nov 2003-18 Feb 2012 \\
\hline El Arenosillo & $\mathrm{N} 37^{\circ} 06^{\prime} 18^{\prime \prime}$ & $\mathrm{W} 06^{\circ} 43^{\prime} 58^{\prime \prime}$ & 1 Mar 2000-21 Feb 2010 \\
\hline Evora & $\mathrm{N} 38^{\circ} 34^{\prime} 04^{\prime \prime}$ & $\mathrm{W} 07^{\circ} 54^{\prime} 43^{\prime \prime}$ & 4 Jul 2003-28 Feb 2013 \\
\hline FORTH CRETE & $\mathrm{N} 35^{\circ} 19^{\prime} 58^{\prime \prime}$ & E $25^{\circ} 16^{\prime} 55^{\prime \prime}$ & 23 Jan 2003-6 Aug 2011 \\
\hline IMC Oristano & N $39^{\circ} 54^{\prime} 36^{\prime \prime}$ & $\mathrm{E} 08^{\circ} 30^{\prime} 00^{\prime \prime}$ & 30 May 2000-28 Feb 2003 \\
\hline IMS METU Erdemli & $\mathrm{N} 36^{\circ} 33^{\prime} 54^{\prime \prime}$ & E $34^{\circ} 15^{\prime} 18^{\prime \prime}$ & 1 Mar 2000-28 Feb 2013 \\
\hline Nes Ziona & $\mathrm{N} 31^{\circ} 55^{\prime} 19^{\prime \prime}$ & E $34^{\circ} 47^{\prime} 20^{\prime \prime}$ & 1 Feb 2000 - 28 Feb 2013 \\
\hline
\end{tabular}

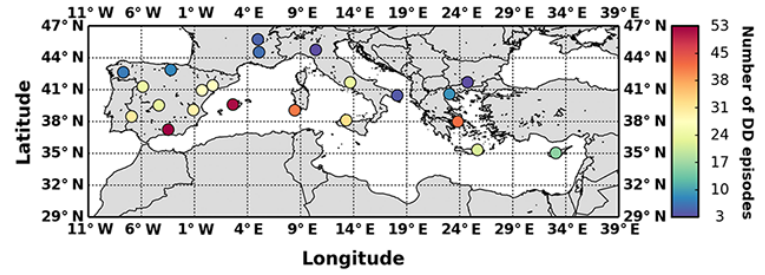

(i)

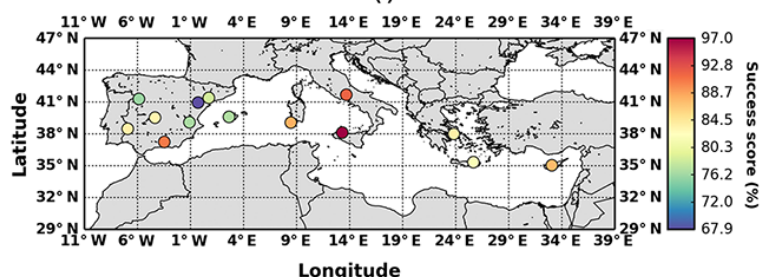

(iii)

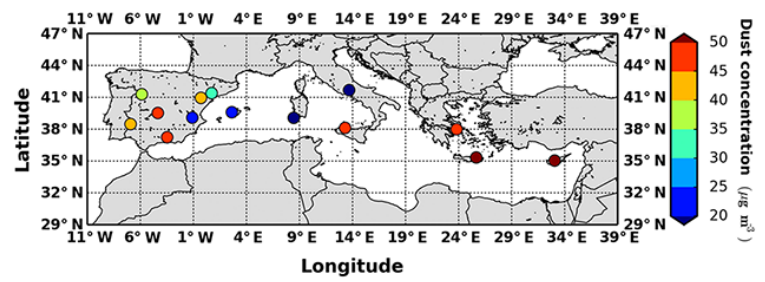

(v)

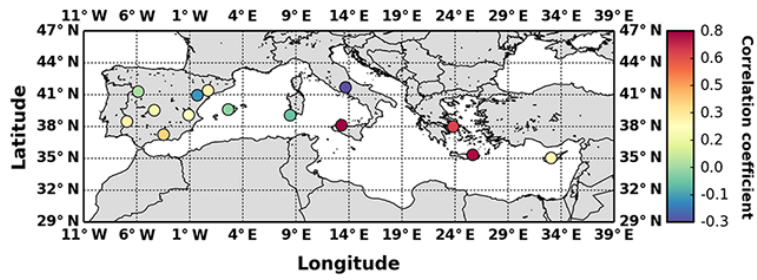

(ii)

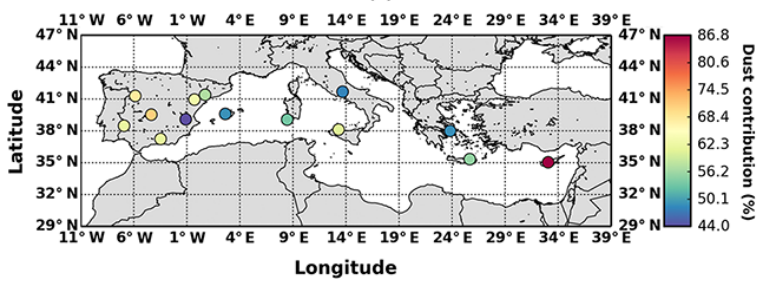

(iv)

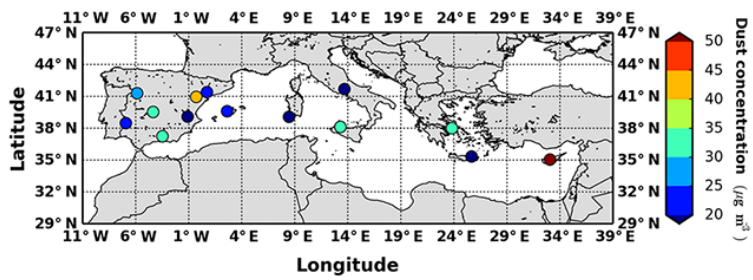

(vi)

Figure 5. (i) Number of concurrent intense DD episodes where total $\mathrm{PM}_{10}$ concentrations and MODIS-Terra AOD retrievals are available, (ii) computed correlation coefficient values between total $\mathrm{PM}_{10}$ concentrations and MODIS-Terra AOD retrievals in stations where at least 10 DD episodes have been recorded, (iii) percentage of intense DD episodes where dust particles have been identified by the ground stations, (iv) dust contribution percentages $(\%)$ to the total $\mathrm{PM}_{10}$ concentrations, (v) calculated mean and (vi) median dust concentrations $\left(\mu \mathrm{g} \mathrm{m}^{-3}\right)$, based on ground measurements for the identified intense DD episodes by the satellite algorithm.

measurements (total $\mathrm{PM}_{10}$ ) are available (Fig. 5i). The number of concurrent DD episodes varies from 3 to 53, generally decreasing from southern to northern stations. For 14 out of 22 stations, where at least 10 intense DD episodes were identified by the satellite-based algorithm, we have computed the correlation coefficients between satellite AODs and surface total $\mathrm{PM}_{10}$ concentrations (Fig. 5ii). The highest $R$ values (up to 0.8) are recorded in the central and eastern parts of the Mediterranean, while the lowest ones are found in the western stations. It must be noted that the correlation coefficients are affected by outliers because of the limited number of DD episodes in each station, highlighting the sensitivity of the intercomparison. Such outliers can be expected when satellite-based columnar AODs and surface-based $\mathrm{PM}_{10}$ data are compared, since satellite AODs are representative for the whole atmospheric column in contrast to in situ PM measurements which are more representative for the lowest part of the planetary boundary layer affected also by local factors. Therefore, the vertical distribution of desert dust load, as it will be presented in the next sections, can determine the level of agreement between satellite AODs and surface PM concentrations.

The identification method via the satellite algorithm can be considered as correct when dust $\mathrm{PM}_{10}$ concentrations are 
Table 2. Percentages of the satellite Ångström exponent, fine fraction, effective radius and aerosol index retrievals satisfying the defined thresholds in the satellite algorithm for the identification of desert dust episodes.

\begin{tabular}{lrrr}
\hline Parameter & Valid & Invalid & $\begin{array}{r}\text { Number of } \\
\text { DD episodes }\end{array}$ \\
\hline Ångström exponent & $97.8 \%$ & $2.2 \%$ & 232 \\
Fine fraction & $98.7 \%$ & $1.3 \%$ & 232 \\
Effective radius & $94.5 \%$ & $5.5 \%$ & 117 \\
Aerosol index & $86.9 \%$ & $13.1 \%$ & 206 \\
\hline
\end{tabular}

higher than zero (i.e. dust has been recorded at the station). According to this, the ratio between the number of non-zero dust PM observations and the number of DD episodes (coincident satellite-derived DD episodes and total $\mathrm{PM}_{10}$ measurements) for each station is defined as success score. The calculated success scores (Fig. 5iii) vary from $68 \%$ (Monagrega, northeastern Spain, 28 episodes) to $97 \%$ (Boccadifalco, Sicily, 33 episodes) confirming the appropriateness of the DD episodes' identification. In the majority of stations, the contribution of dust particles to the total burden (Fig. 5iv) is above $50 \%$, ranging from $44 \%$ (Zarra, Spain) to $86.8 \%$ (Agia Marina, Cyprus). In order to complete our analysis we have also calculated the mean (Fig. 5v) and the median (Fig. 5vi) dust $\mathrm{PM}_{10}$ concentrations for the identified intense DD episodes in each station. The mean $\mathrm{PM}_{10}$ concentrations mainly vary between 20 and $50 \mu \mathrm{g} \mathrm{m}^{-3}$, being higher in the southern stations, as expected. The minimum mean value $\left(17 \mu \mathrm{g} \mathrm{m}^{-3}\right)$ was recorded in Censt (Sardinia) and the maximum one $\left(223 \mu \mathrm{g} \mathrm{m}^{-3}\right)$ in Agia Marina (Cyprus). Our values are much higher than the corresponding ones in Querol et al. (2009b), who obtained that the mean levels of mineral matter in $\mathrm{PM}_{10}$ during dusty days range from 8 to $23 \mu \mathrm{g} \mathrm{m}^{-3}$ based on ground concentrations measured at 21 Mediterranean stations. These differences are reasonable since here only intense desert dust outbreaks associated with high aerosol optical depths are considered. Finally, the median $\mathrm{PM}_{10}$ concentrations are lower compared to the average ones, indicating that outliers (cases with extremely high $\mathrm{AOD}$ or $\mathrm{PM}_{10}$ ) can alter the results, attributed to the fact that both parameters' (AOD and $\mathrm{PM}_{10}$ ) distributions are not Gaussians. For this reason the highest differences are found in Finokalia (Crete) and Agia Marina (Cyprus), where the largest daily $\mathrm{PM}_{10}$ concentrations, equal to 690 and $1291 \mu \mathrm{g} \mathrm{m}^{-3}$, respectively, were recorded during an intense dust outbreak that affected the eastern Mediterranean on 24 and 25 February 2006.

\subsection{2-D geographical distributions of desert dust episodes' frequency and intensity}

The mean geographical distributions of strong and extreme DD episodes' frequency of occurrence (episodes year ${ }^{-1}$ ) are presented in Fig. 6. Results are given separately as obtained from MODIS-Terra and Aqua for the periods March 2000 February 2013 and 2003-2012, corresponding to local late morning-to-noon (Terra) and afternoon (Aqua) conditions, respectively. A gradual reduction of frequencies from south to north is evident, while for the strong DD episodes a west-to-east decreasing gradient also appears. The decreasing south-to-north gradient of intense DD episodes' frequency, which is also in agreement with previous studies based on ground PM measurements (Querol et al., 2009b; Pey et al., 2013), model simulations (Papayannis et al., 2008, 2014) and AERONET AOD retrievals (Basart et al., 2009), can be attributed to the increasing distance from the major dust sources and to the higher precipitation amounts at the northern parts of the basin (e.g. Marrioti et al., 2002; Mehta and Yang, 2008).

The maximum frequencies ( 9.9 episodes year ${ }^{-1}$ ) of strong DD episodes are observed in the western parts of the study region, for both periods and data sets, while the corresponding values for the extreme ones ( 3.3 episodes year ${ }^{-1}$ ) are observed over the central Mediterranean Sea for MODIS-Terra (March 2000-February 2013). In general, there is similar spatial variability between Terra and Aqua, though slightly lower maximum frequencies are found for Aqua. Although intense dust episodes rarely occur across the northern parts of the study region $\left(<1\right.$ and 0.5 episodes year ${ }^{-1}$ for strong and extreme episodes, respectively), their occurrence proves that dust particles can be transported far away from their sources, up to the central (e.g. Klein et al., 2010) or even northern (e.g. Bègue et al., 2012) European areas under favourable meteorological conditions. Our calculated frequencies are significantly lower than the corresponding ones obtained in Pey et al. (2013), who studied the African dust intrusions towards the Mediterranean Basin, based on ground PM concentrations, over the period 2001-2011. The observed deviations between the two studies are mainly attributed to the different thresholds definition and hence strength of dust episodes. Here, focus is given on the intense dust outbreaks (intensity equal/higher than Mean $+2 \times$ SD) while in Pey et al. (2013) the dust occurrences were identified even at very low concentrations $\left(>1 \mu \mathrm{g} \mathrm{m}^{-3}\right)$.

A noticeable difference between the two study periods and platforms is that relatively high frequencies of extreme DD episodes are recorded in more northern latitudes in the Mediterranean Sea, i.e. up to $43^{\circ} \mathrm{N}$, according to MODISTerra over March 2000-February 2013, while they are restricted south of $40^{\circ} \mathrm{N}$ parallel for MODIS-Aqua during 2003-2012. In order to investigate this difference in detail we have also applied the satellite algorithm, over the period 2003-2012, i.e. that of Aqua, using MODIS-Terra retrievals as inputs. Through this analysis (Figs. S5 and S6 in the Supplement), it is evident that there is a very good agreement between the satellite algorithm's outputs, for the periods March 2000-February 2013 and 2003-2012, revealing a constant dust episode's regime. Therefore, the discrepancy 


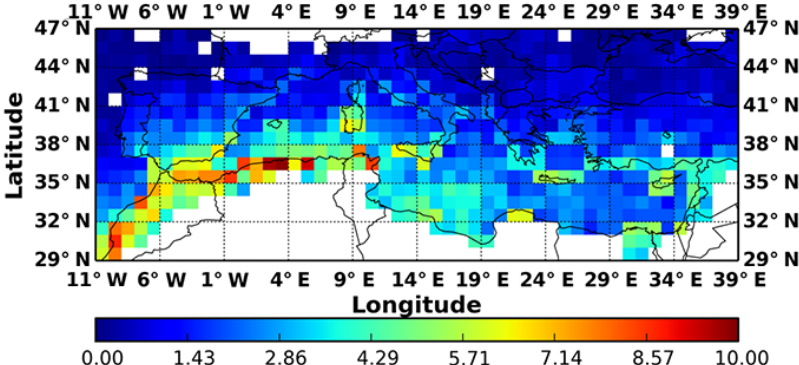

(i-a)

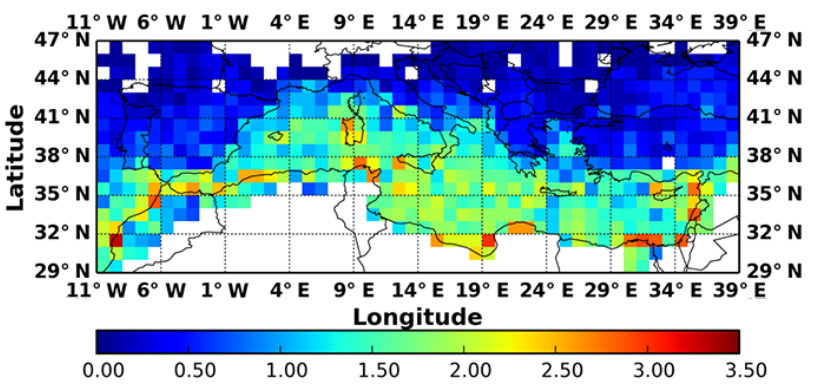

(ii-a)

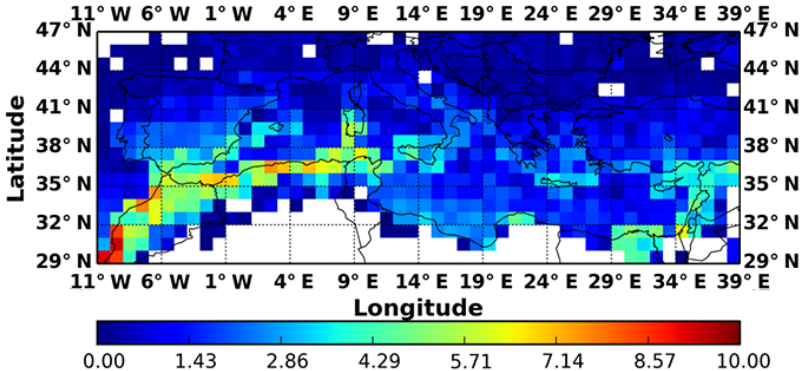

(i-b)

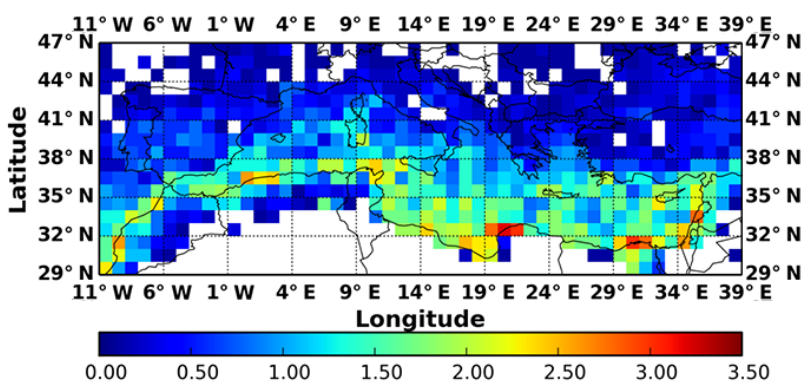

(ii-b)

Figure 6. Geographical distributions of the occurrence frequency (episodes year ${ }^{-1}$ ) of the following: (i) strong and (ii) extreme desert dust episodes, averaged over the following periods: (a) March 2000-February 2013 (MODIS-Terra) and (b) 2003-2012 (MODIS-Aqua), over the broader area of the Mediterranean Basin.

appeared between MODIS-Terra and MODIS-Aqua spatial distributions is attributed to the diurnal variation of factors regulating the emission and transport of dust particles from the sources areas. Schepanski et al. (2009), analysed the variation of the Saharan dust source activation throughout the day, based on MSG-SEVIRI satellite retrievals, reporting that dust mobilization is more intense in the local early morning hours after sunrise. Note that desert dust episodes over the period March 2000-February 2013 have been identified based on observations retrieved by the Terra satellite, which flies over the study region around noon in contrast to Aqua which provides aerosol measurements at early afternoon hours.

The analysis has been also repeated (results not shown here) considering as inputs to the satellite algorithm only AODs associated with cloud fractions lower/equal than 0.8, in order to investigate possible modifications to our results due to the cloud contamination effect. Concerning the strong DD episodes, the geographical distributions are similar with those of Fig. 6, but the maximum frequencies (recorded in Morocco) are higher by up to 2 and 0.3 episodes year $^{-1}$ for the MODIS-Terra (March 2000-February 2013) and MODIS-Aqua (2003-2012) data set, respectively. On the contrary, in the case of extreme DD episodes the maximum frequencies decrease to 2.5 episodes year ${ }^{-1}$ for the period 2003-2012, and they shift southwards, namely over the northern coasts of Africa, while over the central parts of the Mediterranean Sea they are lower than 1 episode year ${ }^{-1}$.
The maps of intensities (in terms of $\mathrm{AOD}_{550 \mathrm{~nm}}$ ) of DD episodes (Fig. 7), show that for both study periods and satellite platforms, the maximum intensities are over the Gulf of Sidra and the Libyan Sea, along the northern African coasts. These intensities reach AODs up to about 1.5 for strong and 4.1 for extreme episodes, while the minimum ones (values down to 0.25-0.46) are recorded in the northern and western Mediterranean parts. Note that dissimilar spatial patterns appear between the geographical distributions of DD episodes' frequency and intensity, indicating that these two features are determined by different factors (e.g. tracks or strength of depressions). Finally, when the cloud contamination is minimized using only AODs associated with CF lower than 0.8, then the maximum intensities are shifted southwards, across the northern Africa and eastern coasts of the Mediterranean, being lower than 1 and 2 for strong and extreme DD episodes, respectively. Through the rejection of possibly overestimated AODs from the data set, it is found that the threshold levels are decreased (mainly over the most frequently dust affected areas) since both mean and standard deviation values are lower (results not shown here). Nevertheless, even though these AODs can be overestimated, in the majority of the cases the collocated AERONET AODs are high (but lower than the satellite observations) indicating the occurrence of desert dust outbreaks, as has also been shown in Sect. "Intercomparison of surface-based and satellite algorithms used for the identification of the desert dust episodes". 


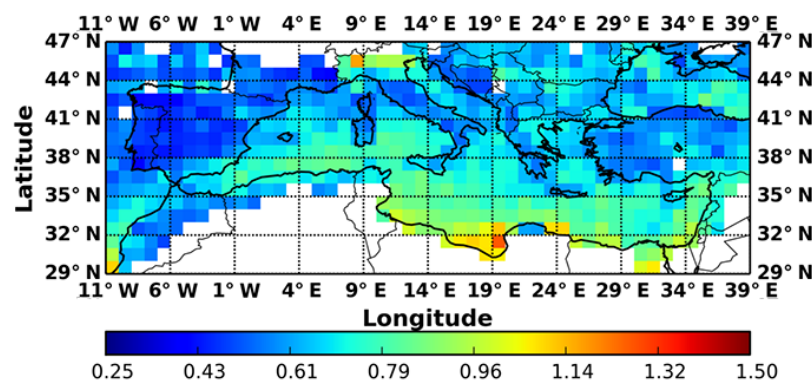

(i-a)

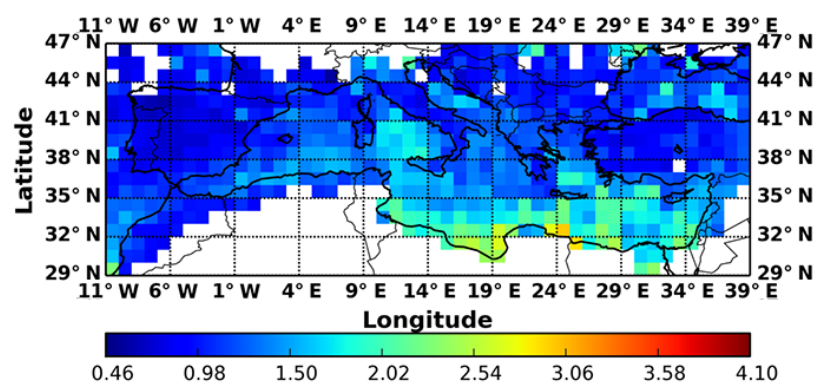

(ii-a)

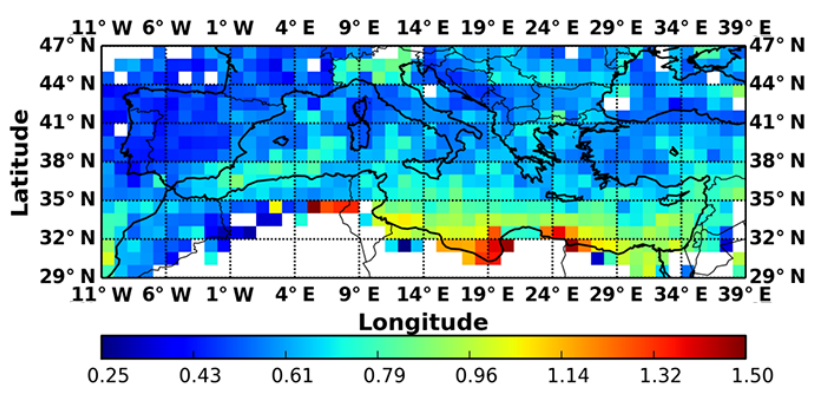

(i-b)

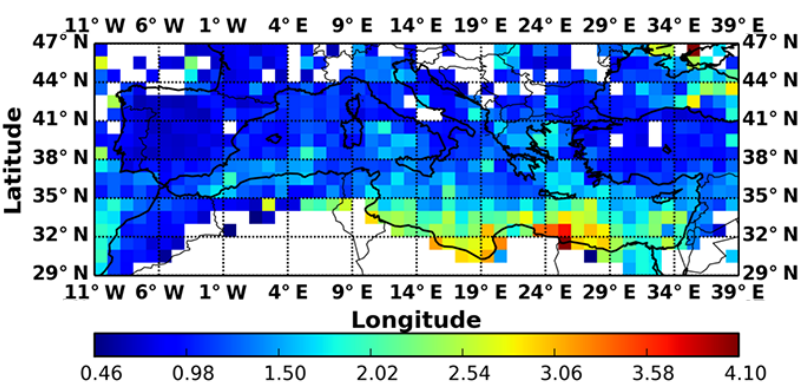

(ii-b)

Figure 7. Geographical distributions of the intensity (in terms of $\mathrm{AOD}_{550 \mathrm{~nm}}$ ) of the following: (i) strong and (ii) extreme desert dust episodes, averaged over the following periods: (a) March 2000-February 2013 (MODIS-Terra) and (b) 2003-2012 (MODIS-Aqua), over the broader area of the Mediterranean Basin.

The analysis has been also repeated applying the alternative METHOD-B described in Sect. 3. Just to ensure a longer temporal coverage, this analysis was done for the period March 2000-February 2013 using MODIS-Terra data. The obtained results for the frequency of occurrence as well as for the intensity of DD episodes are depicted in Figs. S7 and S8, respectively, in the supplementary material. The geographical patterns for the frequency of occurrence between the two methodologies are similar; however, the maximum frequencies of occurrence for the strong and extreme DD episodes can reach up to 13.3 episodes year $^{-1}$ (Fig. S7i) and 8.1 episodes year $^{-1}$ (Fig. S7ii), respectively. Concerning the intensity, the geographical patterns, particularly for the strong DD episodes, are dissimilar and less distinct compared to the corresponding ones obtained with the primary methodology. This difference is attributed to the inclusion of more dust episodes with variable intensity, which leads to a not so clear "signal" when all these episodes are averaged. Based on METHOD-B, the maximum intensities (in terms of $\mathrm{AOD}_{550 \mathrm{~nm}}$ ) of strong DD episodes can reach up to 1 (Fig. S8i) while for the extreme episodes (Fig. S8ii) it can be as large as 3 . The main finding, based on the intercomparison of the two methodologies for the identification of DD episodes, is that the frequency of the episodes is higher for the METHOD-B with respect to the primary methodology, while the intensity is decreased. Both facts are expected and can be explained by the lower calculated AOD thresh- olds with METHOD-B thus yielding more DD episodes of lower intensity.

\subsection{Vertical structure of the Mediterranean desert dust outbreaks}

The ability of the developed satellite algorithm to detect intense dust episodes has been proven adequate through the comparison analysis against AERONET retrievals and $\mathrm{PM}_{10}$ concentrations (Sect. 4.1). Nevertheless, its main limitation is that it uses columnar satellite retrievals and not vertical resolved data prohibiting thus the description of the vertical structure of these dust outbreaks. In order to address this issue, the CALIOP-CALIPSO retrievals are used as a complementary tool for the satellite algorithm's outputs. First, for the dust episodes identified by the satellite algorithm, the spatially and temporally collocated vertically resolved CALIOP lidar observations are selected. For these cases and for each $1^{\circ} \times 1^{\circ}$ grid cell, we have divided the lower troposphere, up to $8 \mathrm{~km}$, in 16 layers of $500 \mathrm{~m}$ height. In this way, 14400 boxes of $1^{\circ} \times 1^{\circ}$ surface area and $500 \mathrm{~m}$ height have been produced. Then, for each one of them, we have calculated the overall number of dust and polluted dust observations (hereafter referred to as "dust") according to the aerosol sub-typing scheme of the CALIOP Vertical Feature Mask (VFM). Note that dust and polluted dust were chosen because in previous studies (Mielonen et al., 2009) they were shown to be the best two defined aerosol types among the other ones classified by the CALIOP VFM. Nevertheless, 
in the case of polluted dust, Burton et al. (2013) reported that dust particles can be mixed with marine aerosols instead of smoke or pollution as assumed by the VFM retrieval algorithm. In our study, more than $95 \%$ of the aerosol type records were pure dust, for the collocated cases between the satellite algorithm and CALIPSO observations. In addition, in the majority of the defined boxes, the percentage of dust from the overall observations is higher than $70 \%$, further confirming the validity of the algorithm DD episodes' identification procedure. This is an excellent proof of the successful identification of DD episodes by the satellite algorithm, since CALIOP-CALIPSO is an independent and vertically resolved platform and database. Thereby, CALIOP vertical observations were subsequently used to examine the vertical structure of dust outbreaks.

In order to analyse the intensity of desert dust outbreaks at different altitudes in the troposphere, the CALIOP data of the total backscatter coefficient at $532 \mathrm{~nm}\left(\beta_{532 \mathrm{~nm}}\right)$ have been also acquired. For each box, the average $\beta_{532 \mathrm{~nm}}$ values have been calculated from all the available CALIOP measurements (day and night), for the identified intense dust episodes by the satellite algorithm. More specifically, the average $\beta_{532 \mathrm{~nm}}$ values were calculated for the dust observations based on the CALIOP VFM associated with CAD scores ranging from -100 to -20 , as proposed by Winker et al. (2013) for discriminating aerosol from clouds. The selection of $\beta_{532 \mathrm{~nm}}$ values instead of extinction coefficients ensures that incorrect lidar ratio assumptions in the CALIOP retrieval algorithm do not affect our results. In the literature, is documented that the CALIOP lidar ratio is underestimated over the northern African deserts and the surrounding areas affected by Saharan dust particles, leading to an underestimation of the columnar AOD compared to MODIS and AERONET retrievals (Redemann et al., 2012; Schuster et al., 2012). Amiridis et al. (2013) stated that an increase of the lidar ratio from 40 to $58 \mathrm{sr}$, along with a series of postcorrections in the CALIOP retrievals and the implementation of several criteria concerning the cloud coverage and the spatial representativeness, can substantially improve the agreement between MODIS-Aqua/AERONET and CALIOP observations.

It should be noted that in the present work, we have analysed all the available CALIOP overpasses $(\sim 10000)$ over the study region, during the period June 2006February 2013. However since similar findings are drawn for MODIS-Aqua (June 2006-December 2012), only the obtained results based on MODIS-Terra retrievals are presented here. Moreover, the analysis (results are not shown here) has been made separately for the identified strong and extreme DD episodes without revealing remarkable differences in the geometrical characteristics of dust outbreaks. Nevertheless, the $\beta_{532 \mathrm{~nm}}$ values are higher for the extreme DD episodes being consistent with the discrimination of dust episodes' intensity (in terms of AOD), which is applied to the satellite algorithm. In order to facilitate the visualization of our re- sults, for each column $\left(1^{\circ} \times 1^{\circ}\right.$ spatial resolution $)$ and latitudinal/longitudinal zone $\left(1^{\circ}\right)$, we have calculated the overall number of dust observations and the associated weighted averages of $\beta_{532 \mathrm{~nm}}$, depending on the projection plane (latitudinal, longitudinal and columnar), according to dust observations in each box. For both parameters, the analysis has been made on an annual and seasonal basis and the corresponding results are discussed in Sects. 4.3.1 and 4.3.2, respectively.

\subsubsection{Annual characteristics}

Figure 8 presents the three-dimensional structure of the CALIOP overall dust observations (Fig. 8i) and the associated average total backscatter coefficients at $532 \mathrm{~nm}$ (Fig. 8ii), during intense dust episodes conditions, over the broader Mediterranean area, for the period June 2006February 2013. From the latitudinal projection in Fig. 8i, it is evident that dust particles are mainly detected between 0.5 and $6 \mathrm{~km}$, and more rarely up to $8 \mathrm{~km}$, between the parallels 32 and $38^{\circ} \mathrm{N}$. The number of dust observations is increased at higher altitudes with increasing latitudes, up to $40^{\circ} \mathrm{N}$, while the altitude range (thickness) where these records are detected is gradually reduced from 4 to $2 \mathrm{~km}$. At northern latitudes, the CALIPSO dust records are drastically reduced and are mainly observed between 1 and $4 \mathrm{~km}$. The ascending mode of the transported mineral particles over the Mediterranean is attributed to the prevailing low pressure systems, which mobilize and uplift dust particles from the source areas across the Sahara and the Arabian Peninsula. Dust aerosols are transported over the planetary boundary layer (Hamonou et al., 1999) due to the upward movement of dry and turbid air masses (Dulac et al., 1992), while the prevailing synoptic conditions also determine the spatial and temporal characteristics of desert dust outbreaks over the Mediterranean (Gkikas et al., 2015).

In general, our results are in agreement with previous studies, based on lidar profiles, which have been made in several Mediterranean sites. More specifically, Papayannis et al. (2008) found that dust layers, over the EARLINET Mediterranean stations, extend from 0.5 to $10 \mathrm{~km}$ above mean sea level, their centre of mass is located between 2.5 and $3.5 \mathrm{~km}$ and their thickness ranges from 2.1 to $3.3 \mathrm{~km}$. Hamonou et al. (1999) reported that dust layers are mainly detected between 1.5 and $5 \mathrm{~km}$ based on lidar measurements in the northwestern and northeastern Mediterranean. According to Di Sarra et al. (2001), who studied the Saharan dust intrusions in Lampedusa (central Mediterranean) for the period May-June 1999, dust particles can be detected up to $7-$ $8 \mathrm{~km}$, which is in line with our findings for the corresponding latitudinal zones $\left(35-36^{\circ} \mathrm{N}\right)$. Balis (2012), analysed 33 Raman/lidar profiles of Saharan dust intrusions over Thessaloniki (northern Greece), and found that the mean base and top of dust layers were equal to $2.5 \pm 0.9$ and $4.2 \pm 1.5 \mathrm{~km}$, respectively. 


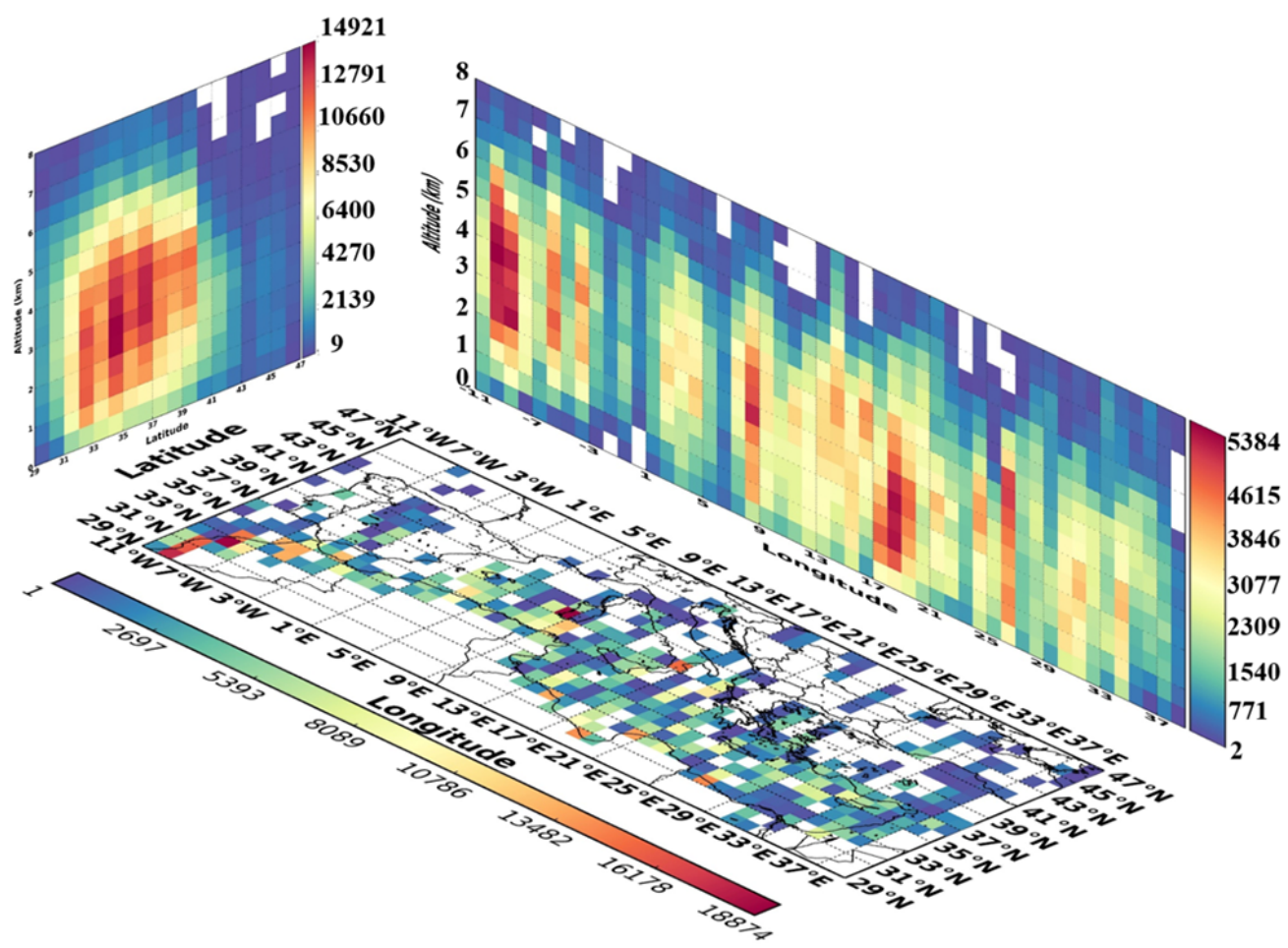

(i)

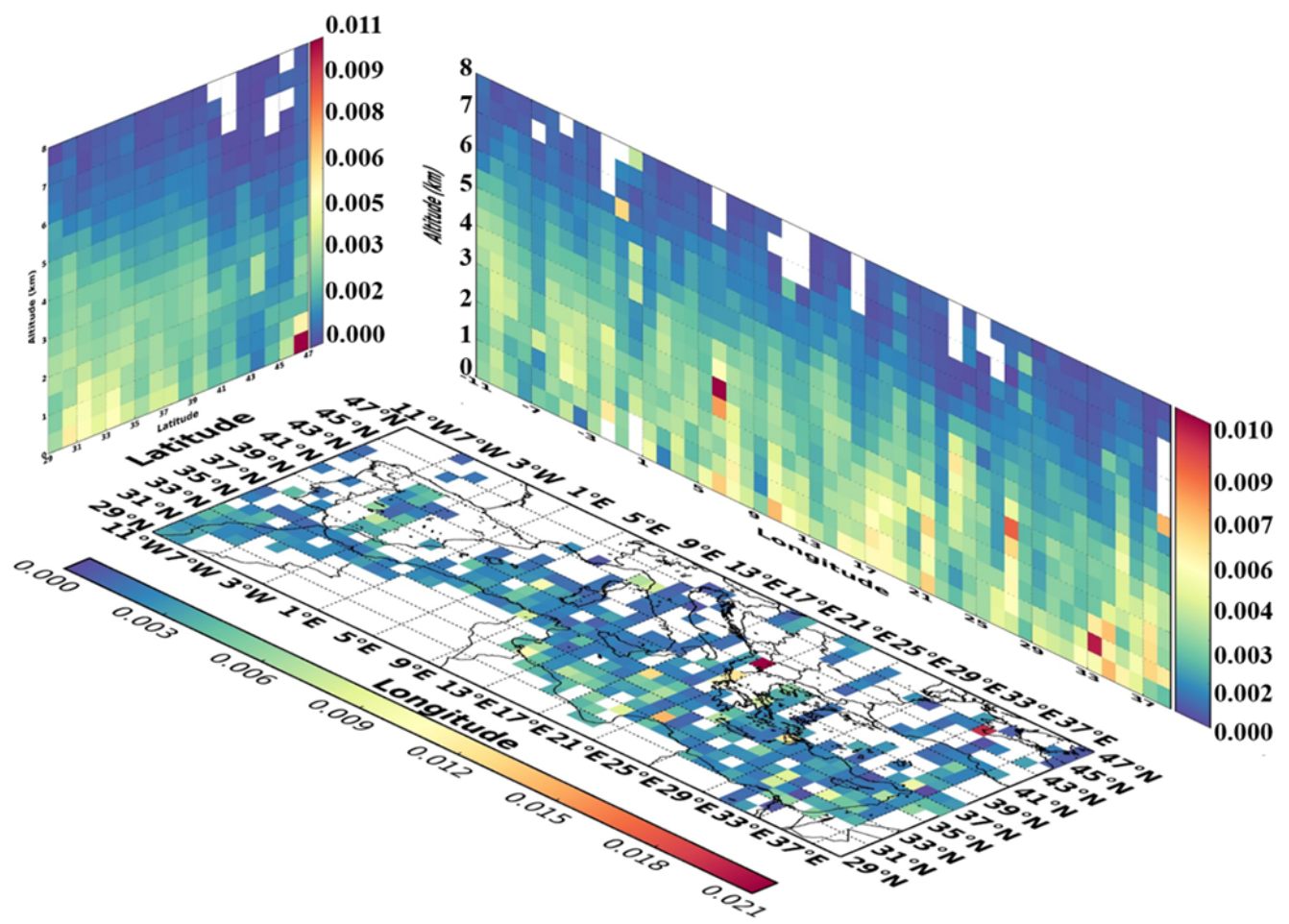

(ii)

Figure 8. Three-dimensional structure of the (i) overall number of dust and polluted dust observations and (ii) total backscatter coefficient at $532 \mathrm{~nm}$ (in $\mathrm{km}^{-1} \mathrm{sr}^{-1}$ ), over the broader Mediterranean Basin under DD episodes conditions, based on CALIOP-CALIPSO vertically resolved retrievals for the period June 2006-February 2013. 
As to the variation of vertical extension with longitude (Fig. 8i), it is revealed that the base height of dust layers is decreased towards the eastern parts of the study region. In the western Mediterranean, the mineral particles are mainly detected between 2 and $6 \mathrm{~km}$, while over the central and eastern Mediterranean the corresponding altitudes are equal to 0.5 and $6 \mathrm{~km}$, respectively. It is well known that dust is transported over the western Mediterranean mainly in summer (e.g. Moulin et al., 1998) favoured by low pressure systems located over the northwestern Africa (Gkikas et al., 2015) and the enhanced thermal convection, uplifting effectively dust aerosols at high altitudes in the troposphere. Moreover, air masses carrying dust particles are "convected" towards higher altitudes due to the position of the Atlas Mountains range. Therefore, the combination of strong convective processes over northern Africa along with topography can explain the identification of dust aerosols at higher tropospheric levels over the western Mediterranean. The presence of mineral particles at high altitudes in western Mediterranean can explain the poor-to-moderate agreement between $\mathrm{PM}_{10}$ concentrations and MODIS AODs found in the Iberian Peninsula (Fig. 5ii). In order to give a better insight to how the dust outbreaks' vertical extension can affect the level of agreement between columnar AOD satellite retrievals and ground $\mathrm{PM}_{10}$ concentrations, emphasis is given at specific dust events, and the relevant findings will be discussed in Sect. 4.4. In the central and eastern parts of the Mediterranean Basin, air masses carrying African dust aerosols travel at lower altitudes over Africa because of the absence of significant topographical objects on their route, as suggested by Pey et al. (2013).

Previous studies have shown that dust layers over the Mediterranean are characterized by a multilayered structure (e.g. Hamonou et al., 1999; Mona et al., 2006; Papayannis et al., 2008). This is also depicted in the longitudinal projection of Fig. 8i, wherein several dust layers of different base/top altitudes and geometrical thicknesses are detected. In general, the base heights vary from 0.5 to $2 \mathrm{~km}$, the top heights from 4 to $6 \mathrm{~km}$, and the thicknesses from 1 to $4 \mathrm{~km}$. The majority of common observations between the CALIOP profiles and the identified intense DD episodes by the satellite algorithm are recorded over the maritime parts of the study region (bottom map of Fig. 8i). The maximum number of CALIOP dust observations $(\sim 19000)$ is recorded along the Atlantic coasts of Morocco, but high numbers (about 10000-15000) are also found across the northern African coasts.

Apart from the CALIOP dust observations, we have also analysed the associated $\beta_{532 \mathrm{~nm}}$ values at the defined altitude ranges in order to describe the variation of intensity of the desert dust episodes with height over the Mediterranean (Fig. 8ii). The maximum backscatter coefficients (up to $0.006 \mathrm{~km}^{-1} \mathrm{sr}^{-1}$ ) are observed below $2 \mathrm{~km}$, being increased towards the southern edges $\left(30-34^{\circ} \mathrm{N}\right)$ of the study region, close to dust source areas. This is explained by the fact that dust particles due to their coarse size and large mass, are efficiently deposited and for this reason they are recorded at higher concentrations near the source areas and at low altitudes. Nevertheless, the decreasing intensity with height towards the north is not so evident. Thus, high $\beta_{532 \mathrm{~nm}}$ values $\left(\sim 0.004 \mathrm{~km}^{-1} \mathrm{sr}^{-1}\right)$ are observed between 2 and $4 \mathrm{~km}$ in the latitudinal zone extending from 35 to $42^{\circ} \mathrm{N}$. Whereas high $\beta_{352}$ values are observed up to $6 \mathrm{~km}$ over north Africa, they are observed to gradually lower altitudes $(4 \mathrm{~km})$ northwards. Any differences in the latitudinal patterns of dust observations and backscatter values (Fig. $8 \mathrm{i}$ and ii) can be explained by the fact that $\beta_{532} \mathrm{~nm}$ values take into account only the dust records and not the overall observations (all aerosol types).

The decrease of backscatter values at higher altitudes has been pointed out in previous studies where lidar profiles have been analysed over specific Mediterranean locations (e.g. Mona et al., 2006; Papayannis et al., 2008). Nevertheless, it must be considered that in the aforementioned studies the lidar measurements are valid above the retrieved planetary boundary layer (Matthias et al., 2004) which varies depending on the location and the season (McGrath-Spangler et al., 2013). Despite the good agreement (concerning the vertical shape of the $\beta_{532 \mathrm{~nm}}$ curves) between our findings and the corresponding findings based on ground retrievals, in the present analysis the calculated backscatter coefficients are generally higher, which is reasonable since only cases of intense desert dust outbreaks are considered.

The longitudinal pattern of $\beta_{532 \mathrm{~nm}}$ profiles (Fig. 8ii) is less distinct compared to the corresponding one resulting from the latitudinal projection. Relatively high $\beta_{532 \mathrm{~nm}}$ values $\left(\sim 0.004 \mathrm{~km}^{-1} \mathrm{sr}^{-1}\right)$ are found between 1 and $5 \mathrm{~km}$ over the western Mediterranean, while over the central and eastern parts of the study region the desert dust outbreaks' intensity $\left(\sim 0.006 \mathrm{~km}^{-1} \mathrm{sr}^{-1}\right)$ is higher below $1.5 \mathrm{~km}$. Among the subregions, the backscatter coefficients are higher in the central and eastern Mediterranean, which is also depicted in the bottom map of Fig. 8ii. Higher intensities of dust episodes over the central and eastern Mediterranean have also been noticed based on MODIS retrievals (Fig. 7). From the obtained longitudinal projection, a patchy structure of the total backscatter coefficient profiles is evident, especially in the central and eastern parts, indicating the existence of several dust layers of varying intensities at different altitudes into the atmosphere.

The three-dimensional plots of Fig. 8i and ii, have been also reproduced considering all the available dust and polluted dust CALIOP-CALIPSO records, without taking into account the satellite algorithm's outputs (intense dust outbreaks). The obtained results for the number of observations and $\beta_{532 \mathrm{~nm}}$ are presented in Fig. S9i and ii, respectively. Note that for each studied parameter, the colour-bar scales in Figs. 8 and S9 are not identical because the number of observations for dust average conditions (Fig. S9i) is much larger than the corresponding one during intense dust outbreaks (Fig. 8i), while the opposite is found for the $\beta_{532 \mathrm{~nm}}$ values (Figs. 8ii and S9ii). It is apparent that the latitudinal projections calculated for the intense dust outbreaks (Fig. 8i) and for all the available CALIOP dust records (Fig. S9i) 
reveal different patterns. More specifically, when all available CALIOP dust records are considered, it is found that dust aerosols are mainly confined between 1 and $3 \mathrm{~km}$ in the southernmost parts of the study region, while the number of observations gradually decreases at higher altitudes and towards northern latitudes (Fig. S9i). On the contrary, during dust outbreaks, mineral particles are transported over the Mediterranean following an ascending path, as it is depicted in the latitudinal projection of Fig. 8i. Nevertheless, it must be mentioned that over the desert areas there is full coverage (see bottom map in Fig. S9i) when all dust CALIOP records are considered in contrast to intense dust outbreaks (see bottom map in Fig. 8i) attributed to the absence of DT retrievals, used as inputs to the satellite algorithm, over bright surfaces. The comparison between the longitudinal projections during intense dust outbreaks (Fig. 8i) and during average dust conditions (Fig. S9i) reveals less remarkable differences than for the latitudinal projections. According to the longitudinal projection of Fig. S9i, in the western Mediterranean, dust layers are confined between 1 and $5 \mathrm{~km}$, while their base and top altitude both decrease down to 0.5 and $4 \mathrm{~km}$, respectively, for increasing longitudes. In the easternmost part of the study region, dust layers are mainly confined between 1 and $3 \mathrm{~km}$, while their top height can reach up to $5 \mathrm{~km}$. The intensity of dust loads (in terms of $\beta_{532 \mathrm{~nm}}$ ) is lower than $0.003 \mathrm{~km}^{-1} \mathrm{sr}^{-1}$ regardless the projection plane for average dust conditions based on CALIOP-CALIPSO lidar profiles (Fig. S9ii). Moreover, the intensity of dust loads decreases gradually with height as well as from south to north, revealing a distinct pattern in all projection planes in contrast to the corresponding ones found during desert dust outbreaks (Fig. 8ii).

\subsubsection{Seasonal characteristics}

The vertical structure of the Mediterranean desert dust outbreaks has also been analysed separately for winter, spring, summer and autumn. The seasonal three-dimensional representations of the CALIOP overall dust observations and the associated total backscatter coefficients are depicted in the left and right column of Fig. 9, respectively. It must be noted that $\beta_{532} \mathrm{~nm}$ colour bars' ranges are common, among the seasons, depending on the projection plane. More specifically, the maximum limits have been set to $0.012,0.014$ and $0.021 \mathrm{~km}^{-1} \mathrm{sr}^{-1}$ for the latitudinal, longitudinal and bottom map projections, respectively. It should be mentioned that $\beta_{532 \mathrm{~nm}}$ values can reach up to $0.045 \mathrm{~km}^{-1} \mathrm{sr}^{-1}$, but are associated with a very small number of dust observations.

The majority $(85 \%)$ of dust observations is recorded in spring and summer, attributed to the enhanced production rates of mineral particles and the prevailing atmospheric circulation over the source areas and the Mediterranean. According to the latitudinal projections, a seasonal variability of the intense Mediterranean desert dust outbreaks' geometrical characteristics is evident. Dust particles are detected at higher altitudes $(6-7 \mathrm{~km})$ during warm seasons of the year while in winter they are mainly detected below $3 \mathrm{~km}$, and in autumn are recorded between 2 and $5 \mathrm{~km}$. Nevertheless, it should be mentioned that during these seasons only a small number of pixels (see bottom maps in Fig. 9i-a, iv-a) is available considering also that clouds prohibit the satellite observations. Note that in spring, dust can be found at low tropospheric levels while in summer it is mainly observed above $1 \mathrm{~km}$ highlighting thus the role of topography and the enhanced thermal convection. During the first half of the year, the maximum dust observations are confined between the parallels 31 and $37^{\circ} \mathrm{N}$ while during the second half, they are shifted northwards in the latitudinal zone extending from 34 to $40^{\circ} \mathrm{N}$. Similar latitudinal projections were also presented by Luo et al. (2015), for the same zonal areas of the study region, who developed a new algorithm to improve CALIOP's ability to detect optically thin dust layers. Also from the longitudinal projections of the bottom maps, it is evident that the maximum dust records are found in different Mediterranean subregions, depending on the season. The geometrical characteristics, in longitudinal terms, of intense DD episodes affecting the western, central and eastern parts of the Mediterranean are similar to those presented in the annual three-dimensional structure (Fig. 8i) being more frequent in the eastern and central Mediterranean in winter, spring and autumn and in the western and central Mediterranean in summer.

The seasonal patterns of $\beta_{532 \mathrm{~nm}}$ latitudinal projections are different than those for the dust observations, while they also differ among the four seasons. The intensity of winter DD episodes is stronger (up to $0.012 \mathrm{~km}^{-1} \mathrm{sr}^{-1}$ ) below $2 \mathrm{~km}$ and at the southern parts of the study region. According to the longitudinal and bottom map projections, these episodes take place over the central and eastern Mediterranean Sea but the number of grid cells with coincident CALIOP observations and DD episodes is limited. In spring, the highest $\beta_{532 \mathrm{~nm}}$ values (up to $0.006 \mathrm{~km}^{-1} \mathrm{sr}^{-1}$ ) are recorded between the parallels 31 and $35^{\circ} \mathrm{N}$ and below $2 \mathrm{~km}$, although relatively high $\beta_{532 \mathrm{~nm}}$ values (up to $0.004 \mathrm{~km}^{-1} \mathrm{sr}^{-1}$ ) are found up to $5 \mathrm{~km}$ (Fig. 9ii-b). Moving northwards, over the Mediterranean, dust layers are mainly confined between 2 and $4 \mathrm{~km}$, associated with high $\beta_{532 \mathrm{~nm}}$ values (up to $0.004 \mathrm{~km}^{-1} \mathrm{sr}^{-1}$ ) in the latitudinal zone extending from 35 to $43^{\circ} \mathrm{N}$. The existence of these elevated dust layers, has also been confirmed by model simulations through specific (Papayannis et al., 2008, 2014) or averaged (Alpert et al., 2004) cross sections of dust concentrations in the central sector of the Mediterranean. This is in accordance with our longitudinal projection (Fig. 9ii-b), where $\beta_{532 \mathrm{~nm}}$ is high, varying from 0.004 to $0.008 \mathrm{~km}^{-1} \mathrm{sr}^{-1}$ at these altitude ranges.

In summer, the intensity of dust episodes is smoothly decreased at higher altitudes, where dust layers of considerable $\beta_{532 \mathrm{~nm}}$ values are also found. More specifically, the highest backscatter coefficients (up to $0.008 \mathrm{~km}^{-1} \mathrm{sr}^{-1}$ ) are recorded near the surface, but also moderate values (up to $0.006 \mathrm{~km}^{-1} \mathrm{sr}^{-1}$ ) are observed between 2 and $5 \mathrm{~km}$, particu- 

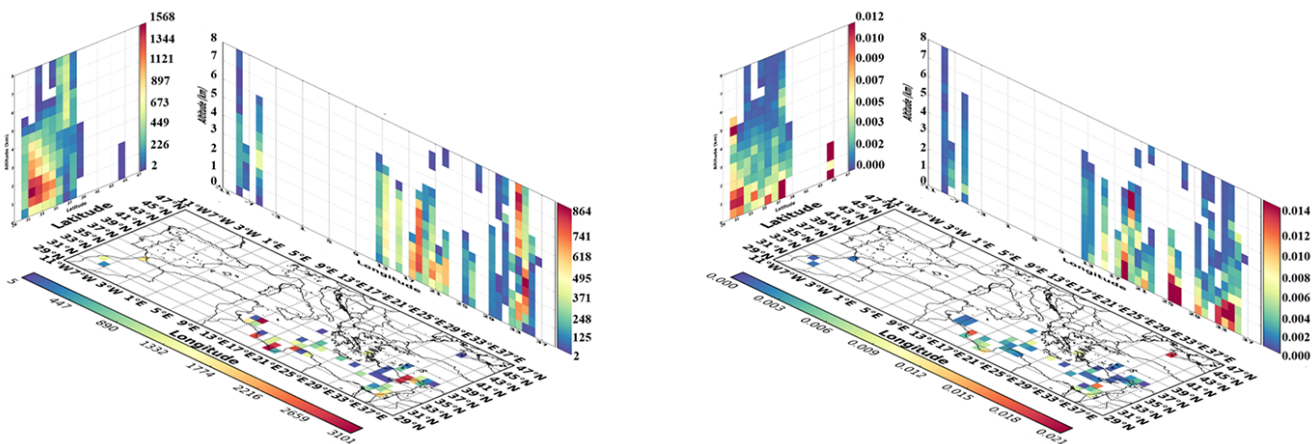

(i-a)

(i-b)
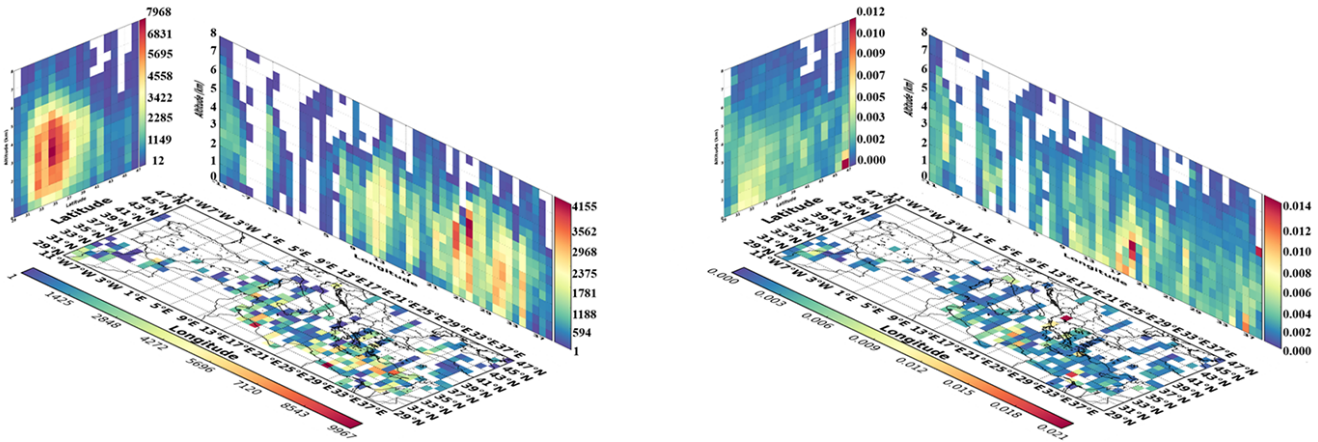

(ii-a)

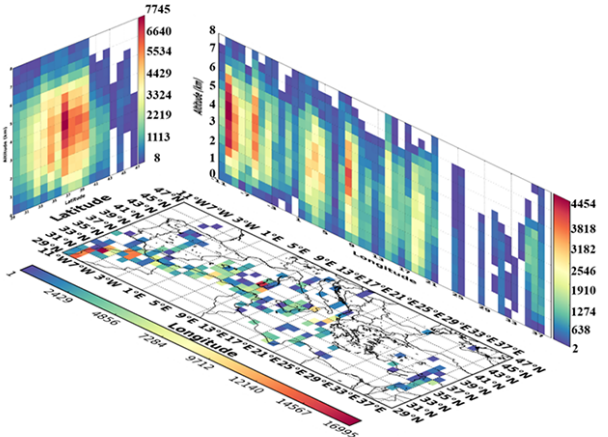

(ii-b)

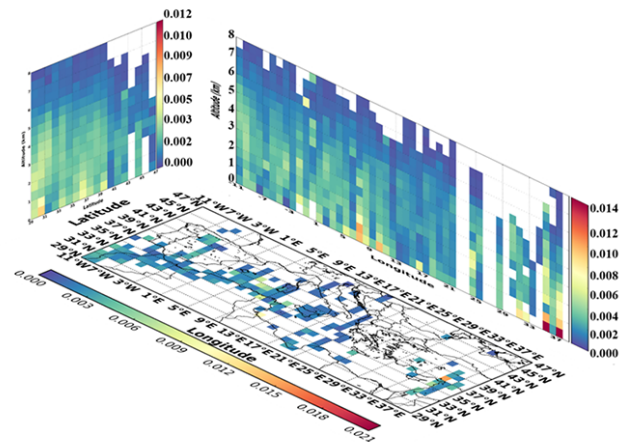

(iii-a)

(iii-b)

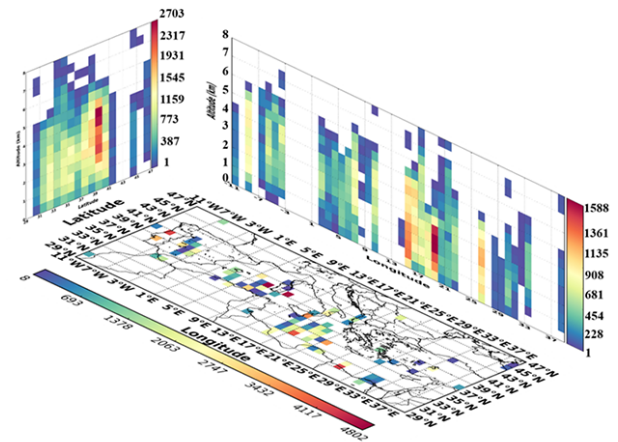

(iv-a)

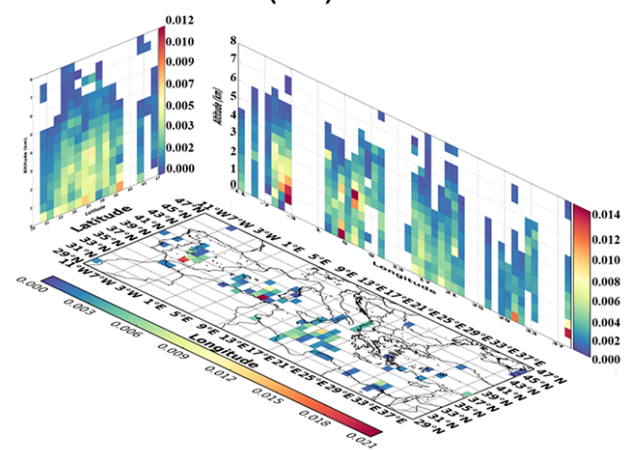

(iv-b)

Figure 9. Three-dimensional representation of the (a) overall number of dust and polluted dust observations and (b) total backscatter coefficient at $532 \mathrm{~nm}$ (in km${ }^{-1} \mathrm{sr}^{-1}$ ), over the broader Mediterranean Basin, under DD episodes conditions, for the following: (i) winter, (ii) spring, (iii) summer and (iv) autumn based on CALIOP-CALIPSO vertically resolved retrievals, over the period June 2006-February 2013. 
larly over the southern parts of the study region (Fig. 9iiib). Most of these intense DD episodes occur in the western Mediterranean, where the highest $\beta_{532 \mathrm{~nm}}$ values (up to $0.005 \mathrm{~km}^{-1} \mathrm{sr}^{-1}$ ) are recorded between 2 and $5 \mathrm{~km}$. Over the central and eastern Mediterranean, even higher $\beta_{532 \mathrm{~nm}}$ values are found (up to $0.014 \mathrm{~km}^{-1} \mathrm{sr}^{-1}$ ) but at lower altitudes $(<1 \mathrm{~km})$. In autumn, the majority of the grid cells of coincident CALIOP profiles and DD episodes identified by the satellite algorithm are located between the parallels 33 and $41^{\circ} \mathrm{N}$. In this latitudinal zone, CALIOP profiles are available over the interior parts of the Iberian Peninsula and over western and central parts of the Mediterranean Sea, near the northern African coasts. According to the latitudinal projection, $\beta_{532 \mathrm{~nm}}$ values mainly vary from 0.002 to $0.009 \mathrm{~km}^{-1} \mathrm{sr}^{-1}$, revealing an increasing tendency for increasing heights. On the contrary, the total backscatter coefficients do not show a distinct spatial pattern on the longitudinal projection, due to the limited number of grid cells participating in the calculations. Throughout the year, based on the CALIOP $\beta_{532 \mathrm{~nm}}$ retrievals, the DD episodes are more intense (up to $0.018 \mathrm{~km}^{-1} \mathrm{sr}^{-1}$ ) in spring, when massive dust loads are transported from the Sahara towards the central and eastern parts of the Mediterranean Sea (bottom map in Fig. 9ii-b).

\subsection{Intercomparison of satellite AOD and $\mathrm{PM}_{10}$ concentrations for specific desert dust outbreaks}

Sect. 4.1.2 shows that the agreement between the satellite algorithm's outputs and $\mathrm{PM}_{10}$ concentrations is better in the central and eastern Mediterranean with regards to the western parts (Fig. 5ii). This discrepancy has been mainly attributed to the higher altitude of dust layers' base over the western sector of the study domain (Fig. 8i), in relation to the existing areal orography. Here, aiming at addressing how dust layers' geometrical characteristics influence the agreement between columnar satellite $\mathrm{AOD}$ and ground $\mathrm{PM}_{10}$ measurements, specific desert dust outbreaks that took place over the $\mathrm{PM}_{10}$ stations are analysed. These outbreaks were selected based on concurrent fulfillment of the following criteria: (i) a DD episode must be identified by the satellite algorithm at pixel level (at $1^{\circ} \times 1^{\circ}$ grid cell), (ii) total $\mathrm{PM}_{10}$ measurement must be available at the station which lies into the geographical limits of the corresponding grid cell and (iii) CALIPSO flies across the grid cell. These criteria were met for 13 desert dust outbreaks, which took place over 9 $\mathrm{PM}_{10}$ stations during the period June 2006-February 2013. Similarities were found among the identified cases and therefore only the results for four desert dust outbreaks of different geometrical characteristics are discussed in the present section. For each case, we have reproduced the cross sections of the $\beta_{532 \mathrm{~nm}}$ vertical profiles up to $8 \mathrm{~km}$ above sea level (a.s.l.) along the CALIOP-CALIPSO track when the satellite flies near the $\mathrm{PM}_{10}$ site (Figs. 10-12). Moreover, the corresponding aerosol subtype profiles, acquired from the CALIOP website (http://www-calipso.larc.nasa.gov/ products/lidar/browse_images/production/), are provided in the Supplement (Figs. S10-S12). Since the $\mathrm{PM}_{10}$ concentrations are available only as daily averages, the optimum solution would be to have the maximum number (2) of CALIOP overpasses near $\mathrm{PM}_{10}$ site throughout the day, in order to reduce the temporal inconsistencies between satellite vertical resolved retrievals and ground data. However, in 8 out of 13 desert dust outbreaks this was not feasible.

\subsubsection{Case 1: 26 May 2008}

The first study case refers to a desert dust outbreak that took place on 26 May 2008 and affected the station Censt (lat.: 39.064; long.: 8.457) located in southern Sardinia. At the ground, the measured mean daily total $\mathrm{PM}_{10}$ concentration was $19 \mu \mathrm{g} \mathrm{m}^{-3}$ whereas $68 \%$ (or $13 \mu \mathrm{g} \mathrm{m}^{-3}$ ) of the load consisted of dust particles indicating thus their strong presence in the lowest troposphere. Based on MODIS-Terra retrievals, representative for the whole atmospheric column and grid cell, the aerosol optical depth at $550 \mathrm{~nm}$ was equal to 0.81 . In order to investigate the vertical distribution of the dust outbreak, the cross sections of the $\beta_{532 \mathrm{~nm}}$ vertical profiles along CALIOP track (near the station during nighttime and daytime) have been reproduced and depicted in Fig. 10i and ii. In addition, the corresponding aerosol subtype profiles are provided in Fig. S10i and ii in the supplementary material. During night, the predominance of a well-developed dust layer mixed with polluted aerosols is evident (Fig. S10i) extending from surface up to $5 \mathrm{~km}$ a.s.l. between the parallels 33 and $38^{\circ} \mathrm{N}$, while near the station its top is lowered down to $3 \mathrm{~km}$ (left side of Fig. 10i). Moreover, the $\beta_{532 \mathrm{~nm}}$ values range mainly from 0.002 to $0.003 \mathrm{~km}^{-1} \mathrm{sr}^{-1}$ without revealing remarkable variations, thus indicating a rather compact dust layer. According to the daytime CALIOP overpass (Fig. 10ii), a pure dust layer (Fig. S10ii) is confined between surface and $4 \mathrm{~km}$, affecting the surrounding area of the station, while its intensity (in terms of $\beta_{532 \mathrm{~nm}}$ ) varies slightly from 0.0015 to $0.002 \mathrm{~km}^{-1} \mathrm{sr}^{-1}$. Nevertheless, due to the background solar illumination, leading thus to a lower signalto-noise ratio (Nowottnick et al., 2015), the "borders" of the dust plume during daytime are not so distinct in contrast to nighttime. According to the obtained results, the groundbased measurements are able to capture satisfactorily the dust event when its load is equally distributed in the lowest tropospheric levels, resulting thus to a good agreement between MODIS and $\mathrm{PM}_{10}$ observations.

\subsubsection{Cases 2 and 3: 16 July 2008 and 12 September 2007}

Two dust events that affected Els Torms (NE Spain, lat.: 41.395; long.: 0.721) and San Pablo (central Spain, lat.: 39.525; long.: -4.353) on 16 July 2008 and 12 September 2007 , respectively, are studied here. The daily aver- 


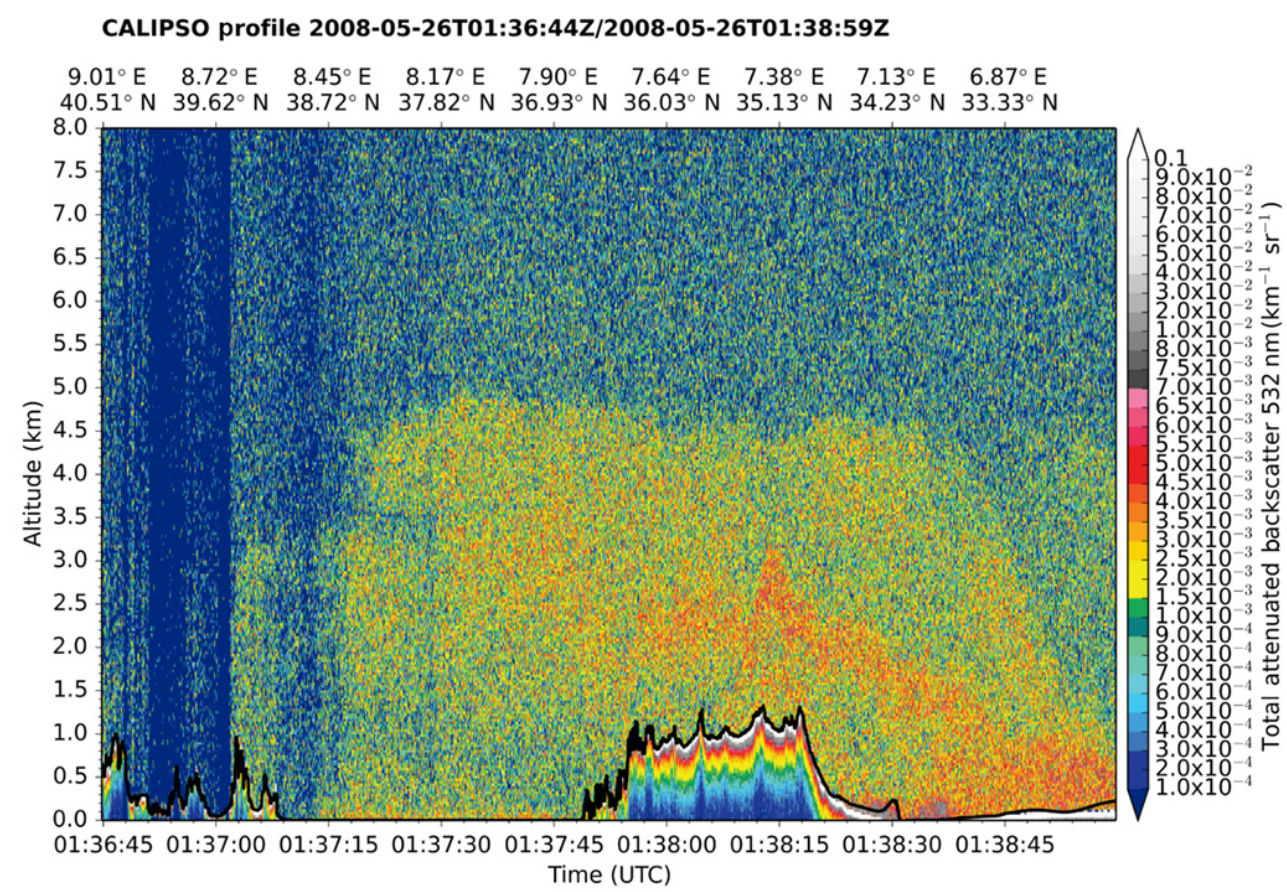

(i)

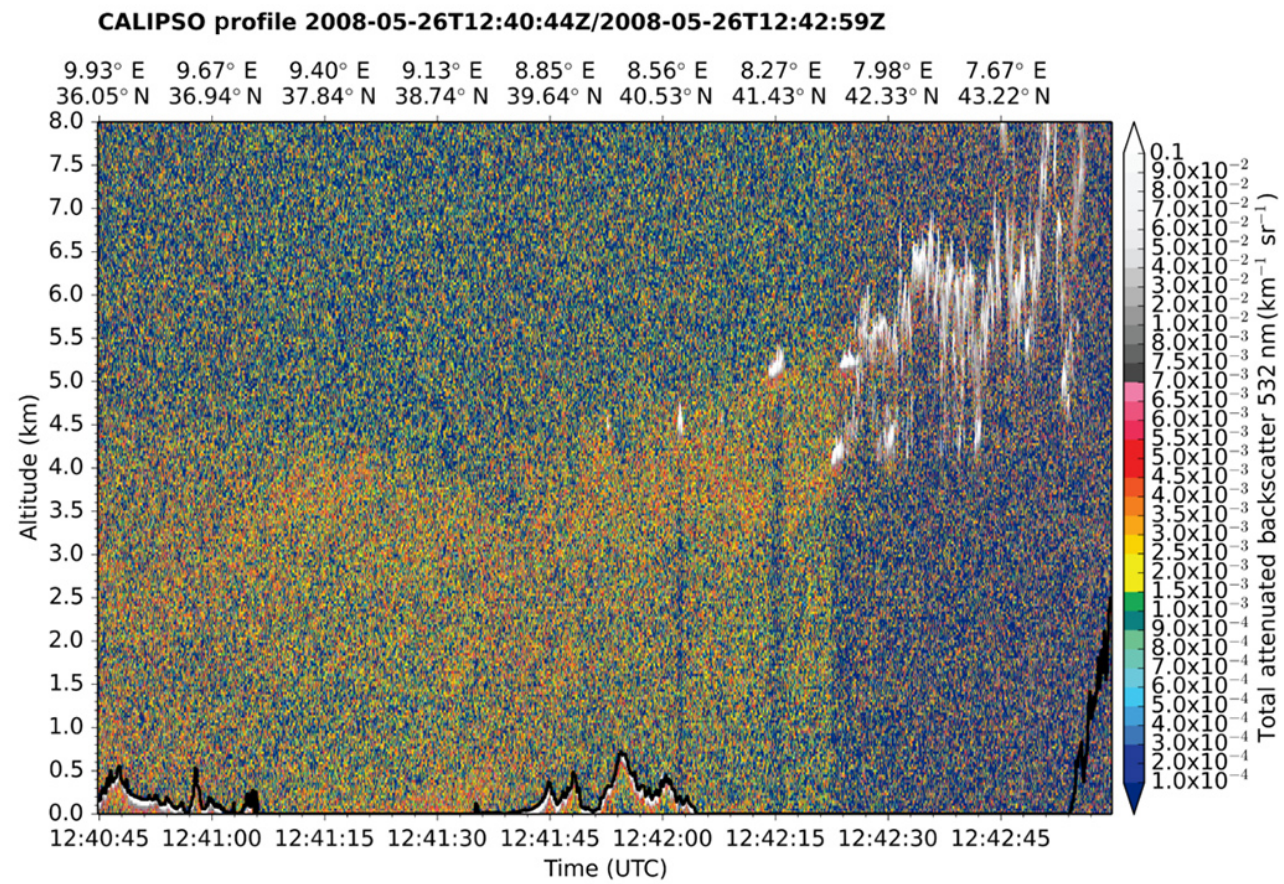

(ii)

Figure 10. Cross sections of the total backscatter coefficient at $532 \mathrm{~nm}$ (in km$~_{-1} \mathrm{sr}^{-1}$ ) vertical profiles along the CALIOP-CALIPSO track during the following: (i) nighttime and (ii) daytime, on 26 May 2008, over the station Censt (lat.: 39.064; long.: 8.457). The black, thick solid line represents the surface elevation. 


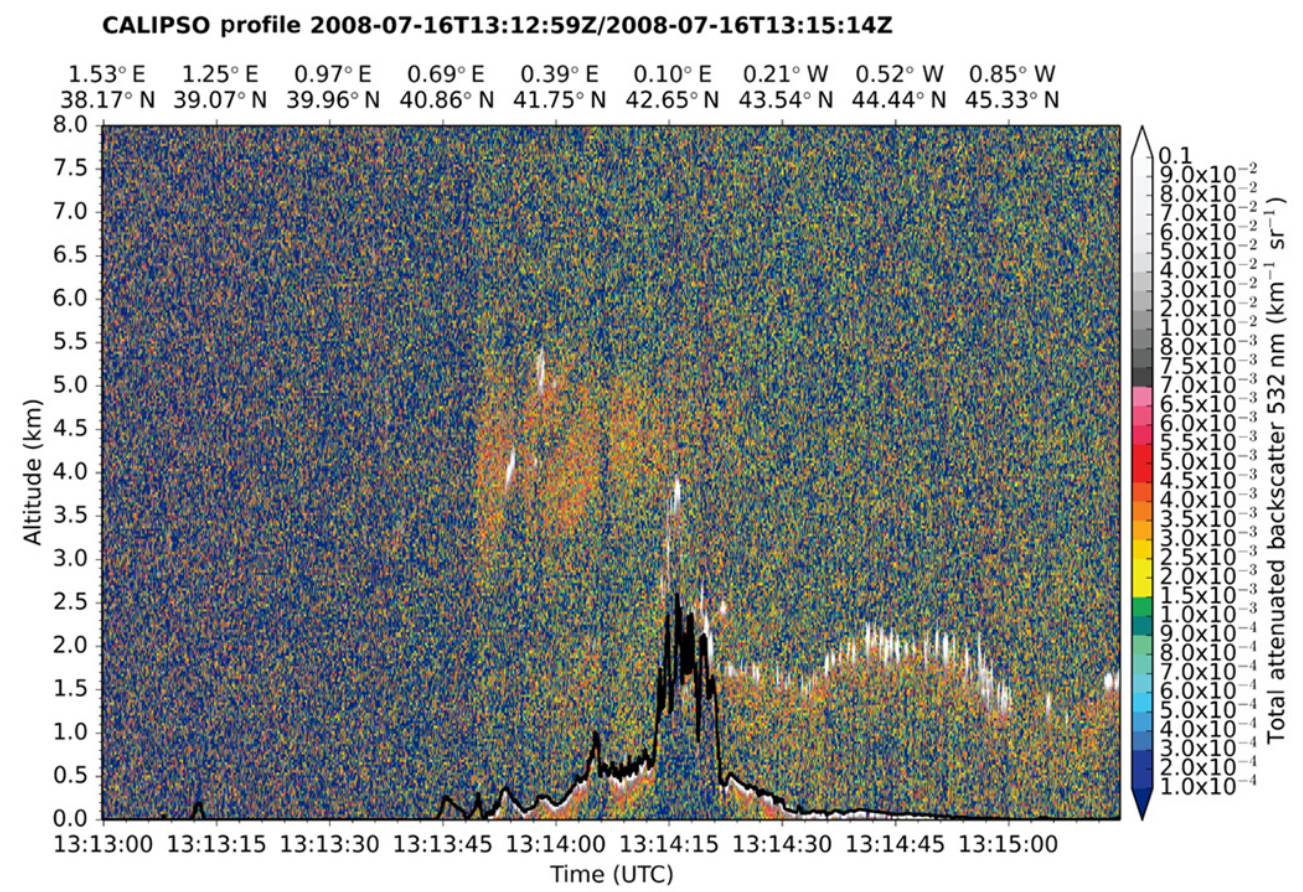

(i)

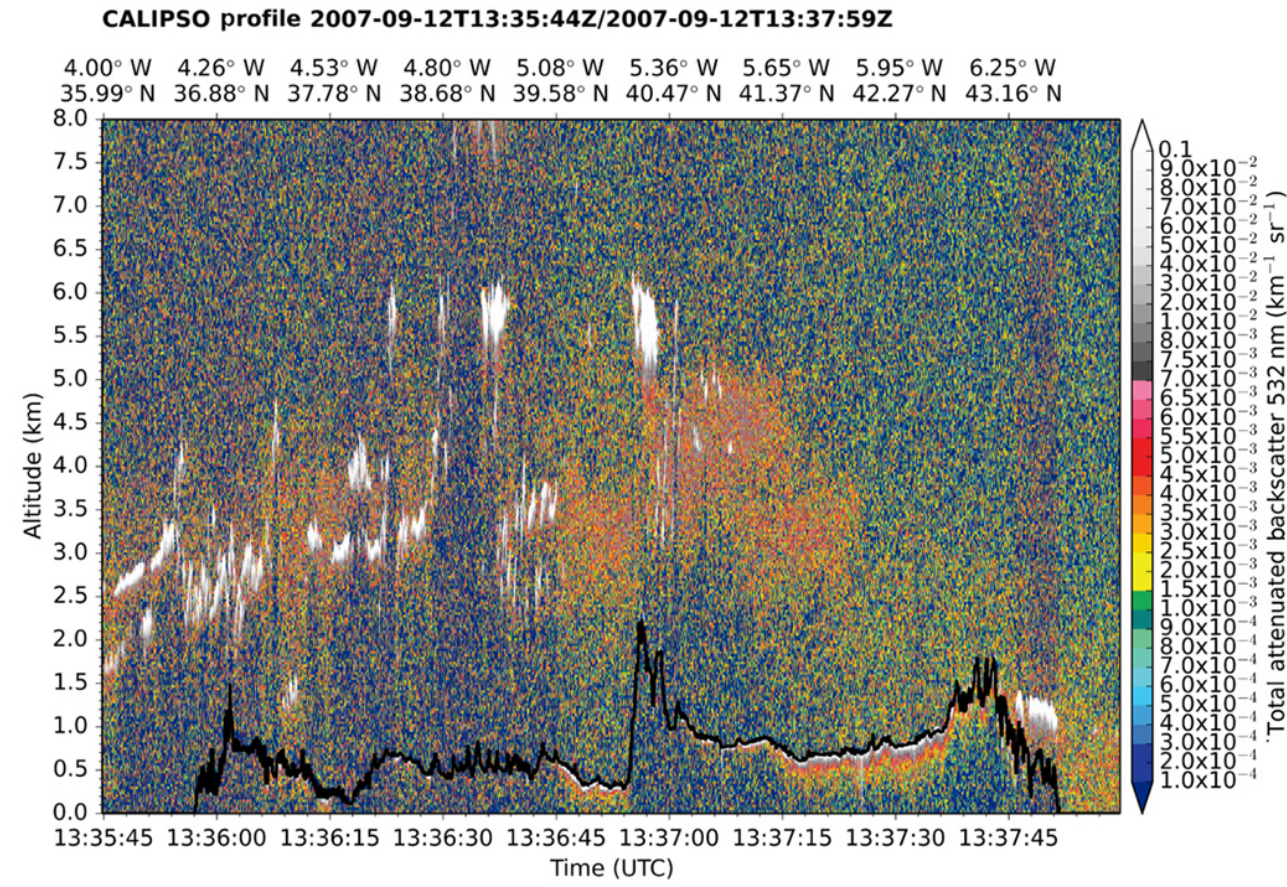

(ii)

Figure 11. Cross sections of the total backscatter coefficient at $532 \mathrm{~nm}$ (in $\mathrm{km}^{-1} \mathrm{sr}^{-1}$ ) vertical profiles along the CALIOP-CALIPSO track during daytime over the stations: (i) Els Torms (lat.: 41.395, long.: 0.721) on 16 July 2008 and (ii) San Pablo (lat.: 39.525; long.: -4.353) on 12 September 2007. The black, thick solid line represents the surface elevation. 


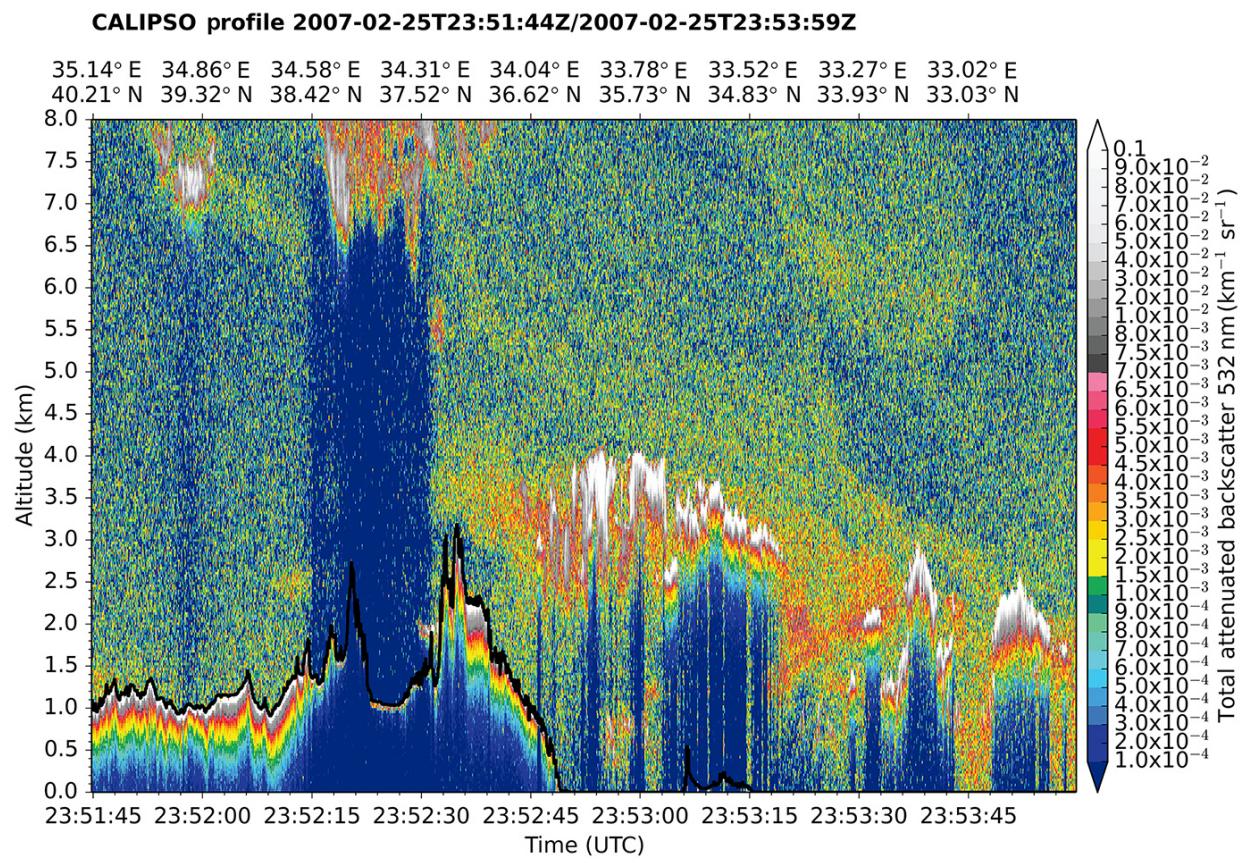

Figure 12. Cross section of the total backscatter coefficient at $532 \mathrm{~nm}$ (in $\mathrm{km}^{-1} \mathrm{sr}^{-1}$ ) vertical profiles along the CALIOP-CALIPSO track during nighttime over the station Agia Marina (lat.: 35.039; long.: 33.058) on 25 February 2007. The black, thick solid line represents the surface elevation.

ages of the total $\mathrm{PM}_{10}$ concentrations were equal to 16 and $30 \mu \mathrm{g} \mathrm{m}^{-3}$, respectively, whereas the dust particles' contribution (dust $\mathrm{PM}_{10}$ ) to the total amount was zero in Els Torms and $33 \%$ in San Pablo. On the contrary, the MODIS-Terra level 3 AOD retrievals were high and equal to 0.56 (Els Torms) and 0.64 (San Pablo), indicating the existence of dust aerosols according to the satellite algorithm's classification method. In order to give a better insight, aiming at describing the discrepancies between MODIS-Terra AOD and $\mathrm{PM}_{10}$ concentrations, we have reproduced the cross sections of the total backscatter at $532 \mathrm{~nm}$ when CALIPSO flies, during daytime, near Els Torms (Fig. 11i) and San Pablo (Fig. 11ii). The corresponding profiles of the CALIOP aerosol classification scheme are also available in Fig. S11i and ii. In Els Torms, where the dust $\mathrm{PM}_{10}$ concentration was zero, a dust layer (Fig. S11i) with its base at $3.5 \mathrm{~km}$ a.s.l. and its top at $5 \mathrm{~km}$ a.s.l., is recorded by the CALIOP lidar between the parallels 41 and $43^{\circ} \mathrm{N}$. The intensity of the elevated dust layer, in terms of $\beta_{532 \mathrm{~nm}}$, varies from 0.002 to $0.004 \mathrm{~km}^{-1} \mathrm{sr}^{-1}$ (Fig. 11i). Through CALIOP lidar profiles, the existence of a dust layer aloft is confirmed, which cannot be captured by the $\mathrm{PM}_{10}$ measurements, in contrast to the MODIS spectroradiometer. In San Pablo, where the dust particles' contribution to the total $\mathrm{PM}_{10}$ load was equal to $33 \%$, a dust layer abuts the ground extending up to 5-6 km a.s.1., whereas the dust plume covers a wide range, in latitudinal terms, from the sub-Sahel to the Celtic Sea, affecting the Iberian Peninsula (Fig. S11ii). Nevertheless, the intensity of the dust layer, over the surrounding area of the station, differs with altitude being higher between 2.5 and $5 \mathrm{~km}$ a.s.l. (0.004 to $\left.0.007 \mathrm{~km}^{-1} \mathrm{sr}^{-1}\right)$ and lower between ground and $2 \mathrm{~km}$ a.s.1. $\left(<0.003 \mathrm{~km}^{-1} \mathrm{sr}^{-1}\right)$, as depicted in the middle of Fig. 11ii. The two studied cases here differ from Case 1 (Sect. 4.4.1) either with regards to the position of the elevated dust layer (Els Torms) or to its vertical distribution (San Pablo), which explains the poor agreement between satellite columnar AOD retrievals (MODIS) and ground $\mathrm{PM}_{10}$ concentrations.

\subsubsection{Case 4: 25 February 2007}

The case studied here, namely the desert dust outbreak recorded in Agia Marina (Cyprus, lat.: 35.039; long.: 33.058) on 25 February 2007, is the strongest one among the selected cases. More specifically, the daily average of the dust $\mathrm{PM}_{10}$ concentration was equal to $134 \mu \mathrm{g} \mathrm{m}^{-3}$ accounting for the $92 \%$ of the total $\mathrm{PM}_{10}$ measured amount at the station, which is indicative of the strong predominance of dust particles in the lowest troposphere. The MODIS-Terra level 3 AOD value for the grid cell to which the station belongs to is high and equal to 1.04. According to the CALIOP aerosol classification scheme, during nighttime, a shallow low-elevated dust layer mixed with polluted or marine aerosols is heading towards the station, whereas above the $\mathrm{PM}_{10}$ site (Agia Marina) it extends from close to the ground up to $9 \mathrm{~km}$ a.s.l., comprising mainly pure dust aerosols (Fig. S12). The main part of the dust layer, in the surrounding area of the station, is confined between 2.5 and $4 \mathrm{~km}$ a.s.l. where the maximum $\beta_{532 \mathrm{~nm}}$ values (up to $0.006 \mathrm{~km}^{-1} \mathrm{sr}^{-1}$ ) are observed 
(Fig. 12). Also, similar $\beta_{532 \mathrm{~nm}}$ values are recorded below $1 \mathrm{~km}$ a.s.l.; however, the dust layer is not well represented in the cross section of the CALIOP $\beta_{532 \mathrm{~nm}}$ vertical profiles due to the total attenuation of the lidar beam by clouds (located between 3 and $4 \mathrm{~km}$ a.s.l.) superimposed to the low-elevated dust layer.

\section{Summary and conclusions}

This study aims at describing the vertical structure of intense desert dust outbreaks affecting the broader Mediterranean Basin. To achieve this target, an updated version of an objective and dynamic algorithm, which has been introduced by Gkikas et al. (2009, 2013), has been applied for the identification of strong and extreme desert dust episodes, over the period March 2000-February 2013. For its operation, a group of optical properties, retrieved by satellite sensors (MODISTerra/Aqua, EP-TOMS and OMI-Aura) on a daily basis, is used, providing information about aerosols' load, size and nature. Briefly, the satellite algorithm operates in three steps; at the first one are computed the mean AOD value (Mean) and the associated standard deviation (SD) for the whole study period in each grid cell of $1^{\circ} \times 1^{\circ}$ spatial resolution, at the second one the identified aerosol episodes are classified based on their intensity into strong and extreme ones. Finally, at the third step the desert dust episodes are identified among these, separately over land and sea. Through this approach the selected data set consists only of intense desert dust episodes since their intensity (expressed in terms of $\mathrm{AOD}_{550 \mathrm{~nm}}$ ) is higher/equal than/to Mean $+2 \times \mathrm{SD}$. In order to check the consistency of the algorithm, the DD episodes have also been determined by applying an alternative second methodology (METHOD-B), which excludes dust-affected cases (from the calculation of mean, standard deviation and thresholds) identified based on the criteria set concerning the aerosol-size/nature-related optical properties.

Through the comparison of the default version of the satellite algorithm against surface measurements derived from 109 AERONET and $22 \mathrm{PM}_{10}$ stations, the following is found.

\section{AERONET}

- The correlation coefficient between MODIS and AERONET AODs is increased from 0.505 to 0.750 when level 3 grid cells with higher sub-grid spatial representativeness and homogeneity are considered.

- According to the AERONET volume size distributions, the predominance of the coarse mode is evident with a peak $\left(\sim 0.25 \mu \mathrm{m}^{3} \mu \mathrm{m}^{-2}\right)$ for particles radii between 1.70 and $2.24 \mu \mathrm{m}$, in the case of intense DD episodes.

- The appropriateness of DD episodes' identification method applied to the satellite algorithm is further confirmed since the majority ( $>75 \%$ ) of AERONET $\alpha_{440-870 \mathrm{~nm}}$ and $r_{\text {eff }}$ values are lower than 0.54 and higher than $0.55 \mu \mathrm{m}$, respectively.

- About $15 \%$ of the pixel level intense DD episodes are misclassified by the satellite algorithm and these drawbacks are encountered in AERONET stations where the aerosol load is dominated either by fine particles or by complex aerosol types.

\section{$\mathbf{P M}_{10}$ and dust contribution}

- The agreement between surface and satellite measurements is better over the central and eastern Mediterranean stations.

- On a station level, the percentage of the intense DD episodes, for which a dust contribution to $\mathrm{PM}_{10}$ surface concentration has been recorded, varies from $68 \%$ (Monagrega, northeastern Spain) to $97 \%$ (Boccadifalco, Sicily).

- In the majority of stations, dust particles contribute more than $50 \%$ of the total amount reaching up to $86.8 \%$ (Agia Marina, Cyprus).

- The mean daily $\mathrm{PM}_{10}$ concentration levels mainly vary from 20 to $50 \mu \mathrm{g} \mathrm{m}^{-3}$ reaching up to $223 \mu \mathrm{g} \mathrm{m}^{-3}$ in Agia Marina (Cyprus).

\section{Regime of desert dust outbreaks}

Based on the satellite algorithm's outputs, an overall view about the regime of Mediterranean desert dust outbreaks is presented for the periods March 2000-February 2013 (MODIS-Terra) and 2003-2012 (MODIS-Aqua). The main findings concerning the intense DD episodes' frequency (in terms of episodes year ${ }^{-1}$ ) and intensity (in terms of AOD at $550 \mathrm{~nm})$ are the following.

- Strong DD episodes occur more frequently (up to 9.9 episodes year $^{-1}$ ) in the western Mediterranean, while the extreme ones occur more frequently (up to 3.3 episodes year ${ }^{-1}$ ) over the central parts of the Mediterranean Sea, when the satellite algorithm operates with MODIS-Terra retrievals.

- The intensity of strong and extreme DD episodes, in AOD terms, can reach to 1.5 and 3-4, respectively, over the central and eastern parts of the Mediterranean Sea, near off the northern African coasts.

- Slightly lower frequencies and higher intensities are found for the period 2003-2012, when the satellite algorithm operates with MODIS-Aqua retrievals.

- Through the intercomparison between the two applied methodologies, it is revealed that the geographical patterns of frequency of occurrence are similar both for strong and extreme DD episodes; however, higher frequencies are found based on METHOD-B. 
- Based on METHOD-B, the DD episodes' intensities are decreased, whereas the geographical patterns for the strong DD episodes are not so distinct compared to the corresponding results obtained by the default version of the satellite algorithm.

- The similarity between the outputs of the algorithm using the two methodologies shows the consistency of the algorithm and the validity of its concept.

\section{Vertical structure of desert dust outbreaks}

In order to describe the vertical structure of the intense Mediterranean dust outbreaks, the CALIOP vertical profiles of aerosol sub-typing and total backscatter coefficient at $532 \mathrm{~nm}$, are used as a complementary tool to the identified intense DD episodes by the satellite algorithm. Through this synergistic approach, the following is found.

- Dust particles are mainly detected between 0.5 and $6 \mathrm{~km}$, following an ascending mode, up to $40^{\circ} \mathrm{N}$, leaving from the source areas and being transported towards the Mediterranean.

- Over the western Mediterranean, the dust layers are mainly observed between 2 and $6 \mathrm{~km}$, while their base height is decreased down to $0.5 \mathrm{~km}$ for increasing longitudes.

- During the warm period of the year, dust particles are uplifted to higher altitudes (up to $8 \mathrm{~km}$ ).

- In summer, the transported dust loads over the western Mediterranean are recorded above $1 \mathrm{~km}$, whereas in spring they are recorded at lower altitudes over the central and eastern parts of the study region. This behaviour underlines the role of topography (e.g. Atlas Mountains) and the enhanced thermal convection.

- The intensity of dust outbreaks, in terms of $\beta_{532 \mathrm{~nm}}$, is maximized (up to $0.006 \mathrm{~km}^{-1} \mathrm{sr}^{-1}$ ) below $2 \mathrm{~km}$ and at the southern parts $\left(30-34^{\circ} \mathrm{N}\right)$ of the study region.

- In spring, considerably high $\beta_{532 \mathrm{~nm}}$ values $\left(\sim 0.004 \mathrm{~km}^{-1} \mathrm{sr}^{-1}\right)$ are observed between 2 and $4 \mathrm{~km}$ in the latitudinal zone extending from 35 to $42^{\circ} \mathrm{N}$.

- Moderate-to-high $\beta_{532 \mathrm{~nm}}$ values are observed up to $6 \mathrm{~km}$, near the source areas, and up to $4 \mathrm{~km}$ towards northern latitudes.

- From the longitudinal projection of $\beta_{532 \mathrm{~nm}}$, it is evident that DD episodes are more intense $\left(\sim 0.004 \mathrm{~km}^{-1} \mathrm{sr}^{-1}\right)$ between 1 and $5 \mathrm{~km}$ in the western Mediterranean, while over the central and eastern sectors, the maximum intensities $\left(\sim 0.006 \mathrm{~km}^{-1} \mathrm{sr}^{-1}\right)$ are recorded below $1.5 \mathrm{~km}$.
- On a seasonal basis, DD episodes are found to be more intense (up to $0.018 \mathrm{~km}^{-1} \mathrm{sr}^{-1}$ ) in spring, when dust is transported towards the central and eastern parts of the Mediterranean region.

At the last part of the present study, it is investigated how the desert dust outbreaks' vertical distribution can affect the level of agreement between columnar satellite AOD retrievals (MODIS) and ground $\mathrm{PM}_{10}$ concentrations. For this purpose, four specific intense Mediterranean desert dust outbreaks of different geometrical characteristics that took place across the Mediterranean, namely in Spain (western), Italy (central) and Cyprus (eastern), are studied. For these four dust outbreaks satellite algorithm's outputs, ground $\mathrm{PM}_{10}$ concentrations and CALIOP-CALIPSO lidar profiles are available concurrently. Our analysis clearly shows that when a well-developed and compact dust layer is located in the lowest tropospheric levels then the level of agreement between MODIS-PM 10 is high. On the contrary, when the dust layer is aloft or its load is not equally distributed in vertical, a poor agreement between MODIS-PM 10 is found.

This study highlights the importance of the synergistic use of active and passive satellite observations and the use of surface-based measurements, in order to ensure the representation of the 3-D structure of dust outbreaks and the description of their spatial and temporal features. For this reason, the further development of the satellite algorithm is an ongoing process by our group, aiming at extending the study domain from the regional to global scale, considering the latest version of MODIS retrievals (Collection 006) as well as the Deep Blue algorithm retrievals, available over the major dust sources of the planet.

\section{Data availability}

The Collection 051 MODIS-Terra and MODIS-Aqua data were obtained from NASA's Level 1 and Atmosphere Archive and Distribution System (LAADS) website (ftp: //ladsweb.nascom.nasa.gov/). The Earth Probe (TOMS) and OMI aerosol climatology is available from the Mirador ftp server (http://mirador.gsfc.nasa.gov/). The CALIPSO retrievals have been derived from NASA's Earth Observing System Data and Information System (http://reverb.echo. nasa.gov/). We would like to thank the principal investigators maintaining the AERONET sites used in the present work. We would like to acknowledge the EMEP Programme and the public European databases Airbase and ACTRIS, which supplied $\mathrm{PM}_{10}$ data used in this study.

\section{The Supplement related to this article is available online at doi:10.5194/acp-16-8609-2016-supplement.}


Acknowledgements. The MDRAF project has received funding from the European Union's Seventh Framework Programme for research, technological development and demonstration under grant agreement no. 622662. The Collection 051 MODIS-Terra and MODIS-Aqua data were obtained from NASA's level 1 and Atmosphere Archive and Distribution System (LAADS) website (ftp://ladsweb.nascom.nasa.gov/). The Earth Probe (TOMS) and OMI aerosol climatology is available from the Mirador ftp server (http://mirador.gsfc.nasa.gov/). The CALIPSO retrievals have been derived from NASA's Earth Observing System Data and Information System (http://reverb.echo.nasa.gov/). We would like to thank the principal investigators maintaining the AERONET sites used in the present work. We would like to acknowledge the EMEP Programme and the public European databases Airbase and ACTRIS, which supplied $\mathrm{PM}_{10}$ data used in this study. J. Pey benefits from a Ramón y Cajal Research Grant (RYC-2013-14159) from the Spanish Ministry of Economy and Competitiveness. S. Basart, O. Jorba, S. Gassó and J. M. Baldasano acknowledge the CICYT project CGL2013-46736 and Severo Ochoa (SEV-996 2011-00067) programme of the Spanish Government. The publication was supported by the European Union Seventh Framework Programme (FP-7-REGPOT-2012-2013-1), in the framework of the project BEYOND, under Grant Agreement No. 316210 (BEYOND - Building Capacity for a Centre of Excellence for EO-based monitoring of Natural Disasters. The Figs. 10, 11 and 12 have been produced with ccplot (http://ccplot.org/). This work contributes to the Chemistry-Aerosol Mediterranean Experiment (ChArMEx) coordinated effort for the long-term Mediterranean aerosol characterization using available remote sensing data sets.

Edited by: F. Dulac

Reviewed by: four anonymous referees

\section{References}

Adams, A. M., Prospero, J. M., and Zhang, C.: CALIPSOderived three-dimensional structure of aerosol over the Atlantic Basin and adjacent continents, J. Climate, 25, 6862-6879, doi:10.1175/JCLI-D-11-00672.1, 2012.

Alados-Arboledas, A., Alcántara, A., Olmo, F. J., Martínez-Lozano, J. A., Estellés, V., Cachorro, V., Silva, A. M., Horvath, H., Gangl, A., Díaz, A., Pujadas, M., Lorente, J., Labajo, A., Sorribas, M., and Pavese, G.: Aerosol columnar properties retrieved from Cimel radiometers during VELETA 2002, Atmos. Environ., 42, 2630-2642, doi:10.1016/j.atmosenv.2007.10.006, 2008.

Alam, K., Trautmann, T., Blaschke, T., and Subhan, F.: Changes in aerosol optical properties due to dust storms in the Middle East and Southwest Asia, Remote Sens. Environ., 143, 216-227, doi:10.1016/j.rse.2013.12.021, 2014.

Alpert, P., Kishcha, P., Shtivelman, A., Krichak, S. O., and Joseph, J. H.: Vertical distribution of Saharan dust based on 2.5-year model predictions, Atmos. Res., 70, 109-130, doi:10.1016/j.atmosres.2003.11.001, 2004.

Amiridis, V., Kafatos, M., Perez, C., Kazadzis, S., Gerasopoulos, E., Mamouri, R. E., Papayannis, A., Kokkalis, P., Giannakaki, E., Basart, S., Daglis, I., and Zerefos, C.: The potential of the synergistic use of passive and active remote sensing measurements for the validation of a regional dust model, Ann. Geophys., 27 , 3155-3164, doi:10.5194/angeo-27-3155-2009, 2009.

Amiridis, V., Wandinger, U., Marinou, E., Giannakaki, E., Tsekeri, A., Basart, S., Kazadzis, S., Gkikas, A., Taylor, M., Baldasano, J., and Ansmann, A.: Optimizing CALIPSO Saharan dust retrievals, Atmos. Chem. Phys., 13, 12089-12106, doi:10.5194/acp-1312089-2013, 2013.

Ångström, A. K.: On the atmospheric transmission of sun radiation and on the dust in the air, Geogr. Ann., 12, 130-159, doi:10.2307/519399, 1929.

Balis, D.: Geometrical characteristics of desert dust layers over Thessaloniki estimated with backscatter/Raman lidar and the BSC/DREAM model, Remote Sens. Lett., 3, 353-362, doi:10.1080/01431161.2011.597793, 2012.

Balis, D., Amiridis, V., Kazadzis, S., Papayannis, A., Tsaknakis, G., Tzortzakis, S., Kalivitis, N., Vrekoussis, M., Kanakidou, M. Mihalopoulos, N., Chourdakis, G., Nickovic, S., Pérez, C., Baldasano, J., and Drakakis, M.: Optical characteristics of desert dust over the East Mediterranean during summer: a case study, Ann. Geophys., 24, 807-821, doi:10.5194/angeo-24-807-2006, 2006.

Barkan, J., Alpert, P., Kutiel, H., and Kishcha, P.: Synoptics of dust transportation days from Africa toward Italy and central Europe, J. Geophys. Res., 110, D07208, doi:10.1029/2004JD005222, 2005.

Barnaba, F. and Gobbi, G. P.: Aerosol seasonal variability over the Mediterranean region and relative impact of maritime, continental and Saharan dust particles over the basin from MODIS data in the year 2001, Atmos. Chem. Phys., 4, 2367-2391, doi:10.5194/acp-4-2367-2004, 2004.

Basart, S., Pérez, C., Cuevas, E., Baldasano, J. M., and Gobbi, G. P.: Aerosol characterization in Northern Africa, Northeastern Atlantic, Mediterranean Basin and Middle East from direct-sun AERONET observations, Atmos. Chem. Phys., 9, 8265-8282, doi:10.5194/acp-9-8265-2009, 2009.

Basart, S., Pay, M. T., Jorba, O., Pérez, C., Jiménez-Guerrero, P., Schulz, M., and Baldasano, J. M.: Aerosols in the CALIOPE air quality modelling system: evaluation and analysis of PM levels, optical depths and chemical composition over Europe, Atmos. Chem. Phys., 12, 3363-3392, doi:10.5194/acp-12-33632012, 2012.

Ben-Ami, Y., Koren, I., and Altaratz, O.: Patterns of North African dust transport over the Atlantic: winter vs. summer, based on CALIPSO first year data, Atmos. Chem. Phys., 9, 7867-7875, doi:10.5194/acp-9-7867-2009, 2009.

Ben-Ami, Y., Koren, I., Rudich, Y., Artaxo, P., Martin, S. T., and Andreae, M. O.: Transport of North African dust from the Bodélé depression to the Amazon Basin: a case study, Atmos. Chem. Phys., 10, 7533-7544, doi:10.5194/acp-10-7533-2010, 2010.

Bègue, N., Tulet, P., Chaboureau, J. P., Roberts, G., Gomes, L., and Mallet, M.: Long-range transport of Saharan dust over northwestern Europe during EUCAARI 2008 campaign: Evolution of dust optical properties by scavenging, J. Geophys. Res., 117, D17201, doi:10.1029/2012JD017611, 2012.

Berthier, S., Chazette, P., Couvert, P., Pelon, J., Dulac, F., Thieuleux, F., Moulin, C., and Pain, T.: Desert dust aerosol columnar properties over ocean and continental Africa from Lidar in-Space Technology Experiment (LITE) 
and Meteosat synergy. J. Geophys. Res., 111, D21202, doi:10.1029/2005JD006999, 2006.

Bhartia, P. K.: OMI/Aura TOMS-Like Ozone, Aerosol Index, Cloud Radiance Fraction Daily L3 Global $1.0 \times 1.0$ deg, version 003, NASA Goddard Space Flight Center, doi:10.5067/Aura/OMI/DATA3001, 2013.

Bollasina, M. A., Ming, Y., and Ramaswamy, V.: Anthropogenic Aerosols and the Weakening of the South Asian Summer Monsoon, Science, 334, 502-505, doi:10.1126/science.1204994, 2011

Bösenberg, J., Matthias, V., Amodeo, A., Amoiridis, V., Ansmann, A., Baldasano, J. M., Balin, I., Balis, D., Böckmann, C., Boselli, A., Carlsson, G., Chaikovsky, A., Chourdakis, G., Comerón, A., De Tomasi, F., Eixmann, R., Freudenthaler, V., Giehl, H., Grigorov, I., Hågård, A., Iarlori, M., Kirsche, A., Kolarov, G., Komguem, L., Kreipl, S., Kumpf, W., Larchevêque, G., Linné, H., Matthey, R., Mattis, I., Mekler, A., Mironova, I., Mitev, V., Mona, L., Müller, D., Music, S., Nickovic, S., Pandolfi,M., Papayannis, A., Pappalardo, G., Pelon, J., Pérez, C., Perrone, R. M., Persson, R., Resendes, D. P., Rizi, V., Rocadenbosch, F., Rodrigues, J. A., Sauvage, L., Schneidenbach, L., Schumacher, R., Shcherbakov, V., Simeonov, V., Sobolewski, P., Spinelli, N., Stachlewska, I., Stoyanov, D., Trickl, T., Tsaknakis, G., Vaughan, G., Wandinger, U., Wang, X., Wiegner, M., Zavrtanik, M., and Zerefos, C.: A European aerosol research lidar network to establish an aerosol climatology, MPI-Rep. 317, Max-Planck Inst. für Meteorol., Hamburg, Germany, available at: http://www.mpimet.mpg.de/fileadmin/publikationen/Reports/ max_scirep_348.pdf (last acce3ss: 28 May 2016), 2003.

Burton, S. P., Ferrare, R. A., Vaughan, M. A., Omar, A. H., Rogers, R. R., Hostetler, C. A., and Hair, J. W.: Aerosol classification from airborne HSRL and comparisons with the CALIPSO vertical feature mask, Atmos. Meas. Tech., 6, 13971412, doi:10.5194/amt-6-1397-2013, 2013.

Cachorro, V. E., Vergaz, R., de Frutos, A. M., Vilaplana, J. M., Henriques, D., Laulainen, N., and Toledano, C.: Study of desert dust events over the southwestern Iberian Peninsula in year 2000: two case studies, Ann. Geophys., 24, 1493-1510, doi:10.5194/angeo24-1493-2006, 2006

CALIPSO Science Team: CALIPSO/CALIOP Level 2, Vertical Feature Mask Data, version 3.01, Hampton, VA, USA: NASA Atmospheric Science Data Center (ASDC), doi:10.5067/CALIOP/CALIPSO/CAL_LID_L2_VFMValStage1-V3-01_L2-003.01 (last access: 26 May 2016), 2015a.

CALIPSO Science Team: CALIPSO/CALIOP Level 2, Vertical Feature Mask Data, version 3.02, Hampton, VA, USA: NASA Atmospheric Science Data Center (ASDC), doi:10.5067/CALIOP/CALIPSO/CAL_LID_L2_VFMValStage1-V3-02_L2-003.02 (last access: 26 May 2016), 2015b.

CALIPSO Science Team: CALIPSO/CALIOP Level 2, Lidar Aerosol Layer Data, version 3.01, Hampton, VA, USA: NASA Atmospheric Science Data Center (ASDC), doi:10.5067/CALIOP/CALIPSO/CAL_LID_L2_05kmALayProv-V3-01_L2-003.01 (last access: 26 May 2016), 2015c.

Cao, C. X., Zheng, S., and Singh, R. P.: Characteristics of aerosol optical properties and meteorological parameters during three major dust events (2005-2010) over Beijing, China, Atmos. Res., 150, 129-142, doi:10.1016/j.atmosres.2014.07.022, 2014.

Córdoba-Jabonero, C., Sorribas, M., Guerrero-Rascado, J. L., Adame, J. A., Hernández, Y., Lyamani, H., Cachorro, V., Gil, M., Alados-Arboledas, L., Cuevas, E., and de la Morena, B.: Synergetic monitoring of Saharan dust plumes and potential impact on surface: a case study of dust transport from Canary Islands to Iberian Peninsula, Atmos. Chem. Phys., 11, 3067-3091, doi:10.5194/acp-11-3067-2011, 2011.

Díaz, J., Tobías, A., and Linares, C.: Saharan dust and association between particulate matter and case-specific mortality: a case crossover analysis in Madrid (Spain), Environ. Health, 11, 1-6, doi:10.1186/1476-069X-11-11, 2012.

Di Sarra, A., Di Iorio, T., Cacciani, M., Fiocco, G., and Fuà, D.: Saharan dust profiles measured by lidar at Lampedusa, J. Geophys. Res., 106, 10335-10348, doi:10.1029/2000JD900734, 2001.

Draxler, R. R. and Rolph, G. D.: HYSPLIT (HYbrid Single-Particle Lagrangian Integrated Trajectory) Model access via NOAA ARL READY Website available at: http://ready.arl.noaa.gov/ HYSPLIT.php, NOAA Air Resources Laboratory, Silver Spring, MD, 2015.

Dubovik, O. and King, M. D.: A flexible inversion algorithm for retrieval of aerosol optical properties from Sun and sky radiance measurements, J. Geophys. Res., 105, 20673-20696, doi:10.1029/2000JD900282, 2000.

Dubovik, O., Smirnov, A., Holben, B. N., King, M. D., Kaufman, Y. J., and Slutsker, I.: Accuracy assessments of aerosol optical properties retrieved from AERONET sun and sky radiance measurements, J. Geophys. Res., 105, 9791-9806, doi:10.1029/2000JD900040, 2000.

Dulac, F., Moulin, C., Lambert, C.E., Guillard, F., Poitou, J., Guelle, W., Quetel, C. R., Schneider, X., Ezat, U., and Buat-Ménard, P.: Dry deposition of mineral aerosol particles in the atmosphere: Significance of the large size fraction, in: Precipitation Scavenging and Atmosphere-Surface Exchange, edited by: Schwartz, S E. and Slinn, W. G. N.,. 841-854, Hemisphere, Richland, Washington, 1992.

Eck, T. F., Holben, B. N., Reid, J. S., Dubovik, O., Smirnov, A., O'Neill, N. T., Slutsker, I., and Kinne, S.: Wavelength dependence of optical depth of biomass burning, urban and desert dust aerosols, J. Geophys. Res., 104, 31333-31350, doi:10.1029/1999JD900923, 1999.

Eguchi, K., Uno, I., Yumimoto, K., Takemura, T., Shimizu, A., Sugimoto, N., and Liu, Z.: Trans-pacific dust transport: integrated analysis of NASA/CALIPSO and a global aerosol transport model, Atmos. Chem. Phys., 9, 3137-3145, doi:10.5194/acp-93137-2009, 2009.

Escudero, M., Querol, X., Pey, J., Alastuey, A., Pérez, N., Ferreira, F., Alonso, S., Rodríguez, S., and Cuevas, E.: A methodology for the quantification of the net African dust load in air quality monitoring networks, Atmos. Environ., 41, 5516-5524, doi:10.1016/j.atmosenv.2007.04.047, 2007.

Fotiadi, A., Hatzianastassiou, N., Drakakis, E., Matsoukas, C., Pavlakis, K. G., Hatzidimitriou, D., Gerasopoulos, E., Mihalopoulos, N., and Vardavas, I.: Aerosol physical and optical properties in the Eastern Mediterranean Basin, Crete, from Aerosol Robotic Network data, Atmos. Chem. Phys., 6, 53995413, doi:10.5194/acp-6-5399-2006, 2006. 
Ginoux, P., Prospero, J. M., Gill, T. E., Hsu, N. C., and Zhao, M.: Global-scale attribution of anthropogenic and natural dust sources and their emission rates based on MODIS Deep Blue aerosol products, Rev. Geophys., 50, RG3005, doi:10.1029/2012rg000388, 2012.

Gkikas, A., Hatzianastassiou, N., and Mihalopoulos, N.: Aerosol events in the broader Mediterranean basin based on 7-year (2000-2007) MODIS C005 data, Ann. Geophys., 27, 35093522, doi:10.5194/angeo-27-3509-2009, 2009.

Gkikas, A., Hatzianastassiou, N., Mihalopoulos, N., Katsoulis, V., Kazadzis, S., Pey, J., Querol, X., and Torres, O.: The regime of intense desert dust episodes in the Mediterranean based on contemporary satellite observations and ground measurements, Atmos. Chem. Phys., 13, 12135-12154, doi:10.5194/acp-1312135-2013, 2013.

Gkikas, A., Houssos, E. E., Lolis, C. J., Bartzokas, A., Mihalopoulos, N., and Hatzianastassiou, N.: Atmospheric circulation evolution related to desert-dust episodes over the Mediterranean, Q. J. Roy. Meteor. Soc., 141, 1634-1645, doi:10.1002/qj.2466, 2015.

Gkikas, A., Hatzianastassiou, N., Mihalopoulos, N., and Torres, O.: Characterization of aerosols episodes in the greater Mediterranean Sea area from satellite observations (2000-2007), Atmos. Environ., 128, 286-304, doi:10.1016/j.atmosenv.2015.11.056, 2016.

Gobbi, G. P., Barnaba, F., Giorgi, R., and Santacasa, A.: Altituderesolved properties of a Saharan dust event over the Mediterranean, Atmos. Environ., 34, 5119-5127, doi:10.1016/S13522310(00)00194-1, 2000.

Gobbi, G. P., Kaufman, Y. J., Koren, I., and Eck, T. F.: Classification of aerosol properties derived from AERONET direct sun data, Atmos. Chem. Phys., 7, 453-458, doi:10.5194/acp-7-453-2007, 2007.

Gobbi, G. P., Angelini, F., Barnaba, F., Costabile, F., Baldasano, J. M., Basart, S., Sozzi, R., and Bolignano, A.: Changes in particulate matter physical properties during Saharan advections over Rome (Italy): a four-year study, 2001-2004, Atmos. Chem. Phys., 13, 7395-7404, doi:10.5194/acp-13-7395-2013, 2013.

Hamonou, E., Chazette, P., Balis, D., Dulac, F., Schneider, X., Galani, E., Ancellet, G., and Papayannis, A.: Characterization of the vertical structure of Saharan dust export to the Mediterranean basin, J. Geophys. Res., 104, 22257-22270, doi:10.1029/1999JD900257, 1999.

Hara, Y., Yumimoto, K., Uno, I., Shimizu, A., Sugimoto, N., Liu, Z., and Winker, D. M.: Asian dust outflow in the PBL and free atmosphere retrieved by NASA CALIPSO and an assimilated dust transport model, Atmos. Chem. Phys., 9, 1227-1239, doi:10.5194/acp-9-1227-2009, 2009.

Hatzianastassiou, N., Gkikas, A., Mihalopoulos, N., Torres, O., and Katsoulis, B. D.: Natural versus anthropogenic aerosols in the eastern Mediterranean basin derived from multiyear TOMS and MODIS satellite data, J. Geophys. Res., 114, D24202, doi:10.1029/2009JD011982, 2009.

Heinold, B., Helmert, J., Hellmuth, O., Wolke, R., Ansmann, A., Marticorena, B., Laurent, B., and Tegen, I.: Regional modeling of Saharan dust events using LM-MUSCAT: Model description and case studies, J. Geophys. Res., 112, D11204, doi:10.1029/2006JD007443, 2007.

Heinold, B., Tegen, I., Schepanski, K., and Hellmuth, O.: Dust Radiative feedback on Saharan boundary layer dynam- ics and dust mobilization, Geophys. Res. Lett., 35, L20817, doi:10.1029/2008GL035319, 2008.

Herman, J. R., Bhartia, P. K., Torres, O., Hsu, N. C., Seftor, C. J., and Celarier E.: Global distribution of UV-absorbing aerosols from Nimbus-7/ TOMS data, J. Geophys. Res., 102, 1691116923, doi:10.1029/96JD03680, 1997.

Holben, B. N., Eck, T. F., Slutsker, I., Tanré, D., Buis, J. P., Setzer, A., Vermote, E., Reagan, J. A., Kaufman, Y. J., Nakajima, T., Lavenu, F., Jankowiak, I., and Smirnov, A.: AERONET - A federated instrument network and data archive for aerosol characterization, Remote Sens. Environ., 66, 1-16, doi:10.1016/S00344257(98)00031-5, 1998.

Huang, J., Minnis, P., Lin, B., Wang, T., Yi, Y., Hu, Y., SunMack, S., and Ayers, K.: Possible influences of Asian dust aerosols on cloud properties and radiative forcing observed from MODIS and CERES, Geophys. Res. Lett., 33, L06824, doi:10.1029/2005GL024724, 2006.

Huang, J., Zhang, C., and Prospero, J. M.: African dust outbreaks: a satellite perspective of temporal and spatial variability over the tropical Atlantic Ocean, J. Geophys. Res., 115, D05202, doi:10.1029/2009JD012516, 2010.

Hubanks, P. A., King, M. D., Platnick, S. A., and Pincus, R. A.: MODIS Atmosphere L3 Gridded Product Algorithm Theoretical Basis Document, MODIS Algorithm Theoretical Basis Document No. ATBD-MOD-30 for Level-3 Global Gridded Atmosphere Products (08 D3, 08 E3, 08M3), avilable at: http://modis-atmos.gsfc.nasa.gov/_docs/L3_ATBD_ 2008_12_04.pdf (last access: 28 May 2016), 2008.

Hunt, W. H, Winker, D. M., Vaughan, M. A., Powell, K. A., Lucker, P. L., and Weimer, C.: CALIPSO Lidar Description and Performance Assessment, J. Atmos. Ocean. Technol., 26, 1214-1228, doi:10.1175/2009JTECHA1223.1, 2009.

IPCC: Summary for Policymakers, in: Climate Change 2013: The Physical Science Basis. Contribution of Working Group I to the Fifth Assessment Report of the Intergovernmental Panel on Climate Change, edited by: Stocker, T. F., Qin, D., Plattner, G.-K., Tignor, M., Allen, S. K., Boschung, J., Nauels, A., Xia, Y., Bex, V., and Midgley, P. M., Cambridge University Press, Cambridge, United Kingdom and New York, NY, USA, 2013.

Kalivitis, N., Gerasopoulos, E., Vrekoussis, M., Kouvarakis, G., Kubilay, N.,Hatzianastassiou, N., Vardavas, I., and Mihalopoulos, N.: Dust transport over the eastern Mediterranean derived from TOMS, AERONET and surface measurements, J. Geophys. Res., 112, D03202, doi:10.1029/2006JD007510, 2007.

Karanasiou, A., Moreno, N., Moreno, T., Viana, M., de Leeuw, F., Querol, X.: Health effects from Sahara dust episodes in Europe: literature review and research gaps, Environ. Int., 15, 107-114, doi:10.1016/j.envint.2012.06.012, 2012.

Karyampudi, V. M., Palm, S. P., Reagen, J. A., Fang, H., Grant, W. B., Hoff, R. M., Moulin, C., Pierce, H. F., Torres, O., Browell, E. V., and Melfi, S. H.: Validation of the Saharan dust plume conceptual model using lidar, Meteosat and ECMWF, B. Am. Meteorol. Soc., 80, 1045-1075, doi:10.1175/15200477(1999)080<1045:VOTSDP>2.0.CO;2, 1999.

Kaufman, Y. J., Tanré, D., Remer, L. A., Vermote, E. F., Chu, A., and Holben, B. N.: Operational remote sensing of tropospheric aerosol over land from EOS Moderate-resolution Imaging Spectroradiometer, J. Geophys. Res., 102, 17051-17065, doi:10.1029/96JD03988, 1997. 
Kaufman, Y. J., Smirnov, A., Holben, B. N., and Dubovik, O.: Baseline maritime aerosol: methodology to derive the optical thickness and the scattering properties, Geophys. Res. Lett., 28, 32513254, doi:10.1029/2001GL013312, 2001.

Kaufman, Y. J., Tanre, D., Holben, B. N., Mattoo, S., Remer, L. A., Eck, T. F., Vaughan, J., and Chatenet, B.: Aerosol radiative impact on spectral solar flux at the surface, derived from principal-plane sky measurements, J. Atmos. Sci., 59, 635-646, doi:10.1175/1520-0469(2002)059<0635:ARIOSS>2.0.CO;2, 2002.

Kazadzis, S., Bais, A., Amiridis, V., Balis, D., Meleti, C., Kouremeti, N., Zerefos, C. S., Rapsomanikis, S., Petrakakis, M., Kelesis, A., Tzoumaka, P., and Kelektsoglou, K.: Nine years of UV aerosol optical depth measurements at Thessaloniki, Greece, Atmos. Chem. Phys., 7, 2091-2101, doi:10.5194/acp-7-20912007, 2007.

Kishcha, P., Barnaba, F., Gobbi, G. P., Alpert, P., Shtivelman, A., Krichak, S. O., and Joseph, J. H.: Vertical distribution of Saharan dust over Rome (Italy): Comparison between 3-year model predictions and lidar soundings, J. Geophys. Res., 110, D06208, doi:10.1029/2004JD005480, 2005.

Klein, H., Nickovic, S., Haunold, W., Bundke, U., Nillius, B., Ebert, M., Weinbruch, S., Schuetz, L., Levin, Z., Barrie, L. A., and Bingemer, H.: Saharan dust and ice nuclei over Central Europe, Atmos. Chem. Phys., 10, 10211-10221, doi:10.5194/acp10-10211-2010, 2010.

Kubilay, N., Cokacar, T., and Oguz, T.: Optical properties of mineral dust outbreaks over the northeastern Mediterranean, J. Geophys. Res., 108, 4666, doi:10.1029/2003JD003798, 2003.

Lau, K. M., Kim, M. K., and Kim, K. M.: Asian summer monsoon anomalies induced by direct forcing: The role of the Tibetan plateau, Clim. Dynam., 26, 855-864, doi:10.1007/s00382-0060114-z, 2006.

Levy, R. C., Remer, L. A., Tanré, D., Kaufman, Y. J., Ichoku, C., Holben, B. N., Livingston, J. M., Russell, P. B., and Maring, H.: Evaluation of the Moderate-Resolution Imaging Spectroradiometer (MODIS) retrievals of dust aerosol over the ocean during PRIDE, J. Geophys. Res., 108, 8594, doi:10.1029/2002JD002460, 2003.

Levy, R. C., Remer, L. A., Kleidman, R. G., Mattoo, S., Ichoku, C., Kahn, R., and Eck, T. F.: Global evaluation of the Collection 5 MODIS dark-target aerosol products over land, Atmos. Chem. Phys., 10, 10399-10420, doi:10.5194/acp-10-10399-2010, 2010.

Liu, D., Wang, Z., Liu, Z., Winker, D., and Trepte, C.: A height resolved global view of dust aerosols from the first year CALIPSO lidar measurements, J. Geophys. Res., 113, D16214, doi:10.1029/2007JD009776, 2008.

Liu, Z., Vaughan, M., Winker, D., Kittaka, C., Getzewich, B., Kuehn, R., Omar, A., Powell, K., Trepte, C., and Hostetler, C.: The CALIPSO Lidar Cloud and Aerosol Discrimination: Version 2 Algorithm and Initial Assessment of Performance, J. Atmos. Ocean. Technol., 26, 1198-1213, doi:10.1175/2009jtecha1229.1, 2009

Luo, T., Wang, Z., Zhang, D., Liu, X., Wang, Y., and Yuan, R.: Global dust distribution from improved thin dust layer detection using A-train satellite lidar observations, Geophys. Res. Lett., 42, doi:10.1002/2014GL062111, 2015.

Lyamani, H., Olmo, F. J., and Alados-Arboledas, L.: Saharan dust outbreak over southeastern Spain as detected by sun photometer, Atmos. Environ., 39, 7276-7284, doi:10.1016/j.atmosenv.2005.09.011, 2005.

Mallet, M., Tulet, P., Serça, D., Solmon, F., Dubovik, O., Pelon, J., Pont, V., and Thouron, O.: Impact of dust aerosols on the radiative budget, surface heat fluxes, heating rate profiles and convective activity over West Africa during March 2006, Atmos. Chem. Phys., 9, 7143-7160, doi:10.5194/acp-9-7143-2009, 2009.

Mallet, M., Dubovik, O., Nabat, P., Dulac, F., Kahn, R., Sciare, J., Paronis, D., and Léon, J. F.: Absorption properties of Mediterranean aerosols obtained from multi-year ground-based remote sensing observations, Atmos. Chem. Phys., 13, 9195-9210, doi:10.5194/acp-13-9195-2013, 2013.

Marrioti, A., Struglia, M. V., Zeng, N., and Lau, K.-M.: The Hydrological Cycle in the Mediterranean Region and Implications for the Water Budget of the Mediterranean Sea, J. Climate, 15, 1674-1690, doi:10.1175/15200442(2002)015<1674:THCITM>2.0.CO;2, 2002.

Matthias, V., Balis, D., Bösenberg, J., Eixmann, R., Iarlori, M., Komguem, L., Mattis, I., Papayannis, A., Pappalardo, G., Perrone, M. R., and Wang, X.: Vertical aerosol distribution over Europe: Statistical analysis of Raman lidar data from 10 European Aerosol Research Lidar Network (EARLINET) stations, J. Geophys. Res., 109, D18201, doi:10.1029/2004JD004638, 2004.

McGrath-Spangler, E. L. and Denning, A. S.: Global Seasonal Variations of Midday Planetary Boundary Layer Depth from CALIPSO Space-borne LIDAR, J. Geophys. Res. Atmos., 118, 1226-1233, doi:10.1002/jgrd.50198, 2013.

Mehta, A. V. and Yang, S.: Precipitation climatology over Mediterranean Basin from ten years of TRMM measurements, Adv. Geosci., 17, 87-91, doi:10.5194/adgeo-17-87-2008, 2008.

Meloni, D., di Sarra, A., Biavati, G., DeLuisi, J. J., Monteleone, F., Pace, G., Piacentino, S., and Sferlazzo, D. M.: Seasonal behavior of Saharan dust events at the Mediterranean island of Lampedusa in the period 1999-2005, Atmos. Environ., 41, 3041-3056, doi:10.1016/j.atmosenv.2006.12.001, 2007.

Meloni, D., di Sarra, A., Monteleone, F., Pace, G., Piacentino, S., and Sferlazzo, D. M.: Seasonal transport patterns of intense Saharan dust events at the Mediterranean island of Lampedusa, Atmos. Res., 88, 134-148, doi:10.1016/j.atmosres.2007.10.007, 2008.

Middleton, N. J. and Goudie, A. S.: Saharan dust: sources and trajectories, T. I. Brit. Geogr., 26, 165-181, doi:10.1111/14755661.00013, 2001.

Mielonen, T., Arola, A., Komppula, M., Kukkonen, J., Koskinen, J., de Leeuw, G., and Lehtinen, K. E. J.: Comparison of CALIOP level 2 aerosol subtypes to aerosol types derived from AERONET inversion data, Geophys. Res. Lett., 36, L18804, doi:10.1029/2009g1039609, 2009.

Mona, L., Amodeo, A., Pandolfi, M., and Pappalardo, G.: Saharan dust intrusions in the Mediterranean area: Three years of Raman lidar measurements, J. Geophys. Res., 111, D16203, doi:10.1029/2005JD006569, 2006.

Mona, L., Liu, Z., Müller, D., Omar, A., Papayannis, A., Pappalardo, G., Sugimoto, N., and Vaughan, M.: Lidar Measurements for Desert Dust Characterization: An Overview, Adv. Meteorol., 2012, 356265, doi:10.1155/2012/356265, 2012.

Mona, L., Papagiannopoulos, N., Basart, S., Baldasano, J., Binietoglou, I., Cornacchia, C., and Pappalardo, G.: EARLINET dust observations vs. BSC-DREAM8b modeled profiles: 12- 
year-long systematic comparison at Potenza, Italy, Atmos. Chem. Phys., 14, 8781-8793, doi:10.5194/acp-14-8781-2014, 2014.

Moulin, C., Lambert, C. E., Dulac, F., and Dayan, U.: Control of atmospheric export of dust from North Africa by the North Atlantic Oscillation, Nature, 387, 691-694, 1997.

Moulin, C., Lambert, C., Dayan, U., Masson, V., Ramonet, M., Bousquet, P., Legrand, M., Balkanski, Y., Guelle, W., Marticorena,B., Bergametti, G., and Dulac, F.: Satellite climatology of African dust transport in the Mediterranean atmosphere, J. Geophys. Res., 103, 13137-13144, doi:10.1029/98JD00171, 1998.

Nabat, P., Somot, S., Mallet, M., Chiapello, I., Morcrette, J. J., Solmon, F., Szopa, S., Dulac, F., Collins, W., Ghan, S., Horowitz, L. W., Lamarque, J. F., Lee, Y. H., Naik, V., Nagashima, T., Shindell, D., and Skeie, R.: A 4-D climatology (1979-2009) of the monthly tropospheric aerosol optical depth distribution over the Mediterranean region from a comparative evaluation and blending of remote sensing and model products, Atmos. Meas. Tech., 6, 1287-1314, doi:10.5194/amt-6-1287-2013, 2013.

Nabat, P., Somot, S., Mallet, M., Michou, M., Sevault, F., Driouech, F., Meloni, D., di Sarra, A., Di Biagio, C., Formenti, P., Sicard, M., Léon, J.-F., and Bouin, M.-N.: Dust aerosol radiative effects during summer 2012 simulated with a coupled regional aerosolatmosphere-ocean model over the Mediterranean, Atmos. Chem. Phys., 15, 3303-3326, doi:10.5194/acp-15-3303-2015, 2015.

Nowottnick, E. P., Colarco, P. R., Welton, E. J., and da Silva, A.: Use of the CALIOP vertical feature mask for evaluating global aerosol models, Atmos. Meas. Tech., 8, 3647-3669, doi:10.5194/amt-8-3647-2015, 2015.

Omar, A. H., Winker, D. M., Kittaka, C., Vaughan, M. A., Liu, Z. Y., Hu, Y. X., Trepte, C. R., Rogers, R. R., Ferrare, R. A., Lee, K. P., Kuehn, R. E., and Hostetler, C. A.: The CALIPSO automated aerosol classification and lidar ratio selection algorithm, J. Atmos. Ocean. Technol., 26, 1994-2014, doi:10.1175/2009jtecha1231.1, 2009.

O’Neill, N. T., Eck, T. F., Smirnov, A., Holben, B. N., and Thulasiraman, S.: Spectral discrimination of coarse and fine mode optical depth, J. Geophys. Res.-Atmos., 108, 4559, doi:10.1029/2002JD002975, 2003.

Pace, G., di Sarra, A., Meloni, D., Piacentino, S., and Chamard, P.: Aerosol optical properties at Lampedusa (Central Mediterranean). 1. Influence of transport and identification of different aerosol types, Atmos. Chem. Phys., 6, 697-713, doi:10.5194/acp-6-697-2006, 2006.

Papadimas, C. D., Hatzianastassiou, N., Mihalopoulos, N., Querol, $\mathrm{X}$., and Vardavas, I.: Spatial and temporal variability in aerosol properties over the Mediterranean basin based on 6year (2000-2006) MODIS data, J. Geophys. Res., 113, D11205, doi:10.1029/2007JD009189, 2008.

Papadimas, C. D., Hatzianastassiou, N., Mihalopoulos, N., Kanakidou, M., Katsoulis, B. D., and Vardavas, I.: Assessment of the MODIS Collections C005 and C004 aerosol optical depth products over the Mediterranean basin, Atmos. Chem. Phys., 9, 29872999, doi:10.5194/acp-9-2987-2009, 2009.

Papayannis, A., Balis, D., Amiridis, V., Chourdakis, G., Tsaknakis, G., Zerefos, C., Castanho, A. D. A., Nickovic, S., Kazadzis, S., and Grabowski, J.: Measurements of Saharan dust aerosols over the Eastern Mediterranean using elastic backscatter-Raman lidar, spectrophotometric and satellite observations in the frame of the EARLINET project, Atmos. Chem. Phys., 5, 2065-2079, doi:10.5194/acp-5-2065-2005, 2005.

Papayannis, A., Amiridis, V., Mona, L., Tsaknakis, G., Balis, D., Bösenberg, J., Chaikovski, A., De Tomasi, F., Grigorov, I., Mattis,I., Mitev, V., Muller, D., Nickovic, S., Pérez, C., Pietruczuk, A., Pisani, G., Ravetta, F., Rizi, V., Sicard, M., Trickl, T., Wiegner, M., Gerding, M., Mamouri, R. E., D’Amico, G., and Pappalardo, G.: Systematic lidar observations of Saharan dust over Europe in the frame of EARLINET (2000-2002), J. Geophys. Res., 113, D10204, doi:10.1029/2007JD009028, 2008.

Papayannis, A., Mamouri, R. E., Amiridis, V., Kazadzis, S., Pérez, C., Tsaknakis, G., Kokkalis, P., and Baldasano, J. M.: Systematic lidar observations of Saharan dust layers over Athens, Greece in the frame of EARLINET project (2004-2006), Ann. Geophys., 27, 3611-3620, doi:10.5194/angeo-27-3611-2009, 2009.

Papayannis, A., Nicolae, D., Kokkalis, P., Binietoglou, I., Talianu, C., Belegante, L., Tsaknakis, G., Cazacu, M. M., Vetres, I., and Ilic, L.: Optical, size and mass properties of mixed type aerosols in Greece and Romania as observed by synergy of lidar and sunphotometers in combination with model simulations: A case study, Sci. Total Environ., 500-501, 277-294, doi:10.1016/j.scitotenv.2014.08.101, 2014.

Pereira, S. N., Wagner, F., and Silva, A. M.: Seven years of measurements of aerosol scattering properties, near the surface, in the southwestern Iberia Peninsula, Atmos. Chem. Phys., 11, 1729, doi:10.5194/acp-11-17-2011, 2011.

Pérez, C., Nickovic, S., Pejanovic, G., Baldasano, J. M., and Özsoy, E.: Interactive dust-radiation modeling: A step to improve weather forecasts, J. Geophys. Res., 111, D16206, doi:10.1029/2005JD006717, 2006.

Pérez García-Pando, C., Stanton, M. C., Diggle, P. J., Trzaska, S., Miller, R. L., Perlwitz, J. P., Baldasano, J. M., Cuevas, E., Ceccato, P., Yaka, P., and Thomson, M. C.: Soil Dust Aerosols and Wind as Predictors of Seasonal Meningitis Incidence in Niger, Environ. Health Perspect., 122, 679-686, doi:10.1289/ehp.1306640, 2014.

Pey, J., Querol, X., Alastuey, A., Forastiere, F., and Stafoggia, M.: African dust outbreaks over the Mediterranean Basin during 2001-2011: $\mathrm{PM}_{10}$ concentrations, phenomenology and trends, and its relation with synoptic and mesoscale meteorology, Atmos. Chem. Phys., 13, 1395-1410, doi:10.5194/acp-13-13952013, 2013.

Pisani, G., Boselli, A., Spinelli, N., and Wang, X.: Characterization of Saharan dust layers over Naples (Italy) during 2000-2003 EARLINET project, Atmos. Res., 102, 286-299, doi:10.1016/j.atmosres.2011.07.012, 2011.

Prospero, M. J., Ginoux, P., Torres, O., Nicholson, S. E., and Gill,T. E.: Environmental characterization of global sources of atmospheric soil dust identified with the Nimbus 7 Total Ozone Mapping Spectrometer (TOMS) absorbing aerosol product, Rev. Geophys., 40, 1002, doi:10.1029/2000RG000095, 2002.

Prospero, J. M. and Lamb, P. J.: African droughts and dust transport to the Caribbean: climate change mplications, Science, 302 , 1024-1027, doi:10.1126/science.1089915, 2003.

Querol, X., Alastuey, A., Lopez-Soler, A., Plana, F., Puicercus, J. A., Mantilla, E., and Miro, J. V.: Artiñano B.: Seasonal evolution of atmospheric suspended particles around a coal-fired power station: Particulate levels and sources, Atmos. Environ. 32, 1963-1978, doi:10.1016/S1352-2310(97)00504-9, 1998. 
Querol, X., Alastuey, A., Pey, J., Cusack, M., Pérez, N., Mihalopoulos, N., Theodosi, C., Gerasopoulos, E., Kubilay, N., and Koçak, M.: Variability in regional background aerosols within the Mediterranean, Atmos. Chem. Phys., 9, 4575-4591, doi:10.5194/acp-9-4575-2009, 2009a.

Querol, X., Pey, J., Pandolfi, M., Alastuey, A., Cusack, M., Pérez, N., Moreno, T., Viana, N., Mihalopoulos, N., Kallos, G., and Kleanthous, S.: African dust contributions to mean ambient $\mathrm{PM}_{10}$ mass-levels across the Mediterranean basin, Atmos. Environ., 43, 4266-4277, doi:10.1016/j.atmosenv.2009.06.013, 2009b.

Redemann, J., Vaughan, M. A., Zhang, Q., Shinozuka, Y., Russell, P. B., Livingston, J. M., Kacenelenbogen, M., and Remer, L. A.: The comparison of MODIS-Aqua (C5) and CALIOP (V2 \& V3) aerosol optical depth, Atmos. Chem. Phys., 12, 3025-3043, doi:10.5194/acp-12-3025-2012, 2012.

Remer, L. A., Tanré, D., Kaufman, Y. J., Ichoku, C., Mattoo, S., Levy, R., Chu, D. A., Holben, B., Dubovik, O., Smirnov, A., Martins, J. V., Li, R.-R., and Ahman, Z.: Validation of MODIS aerosol retrieval over ocean, Geophys. Res. Lett., 29, 8008, doi:10.1029/2001GL013204, 2002.

Remer, L. A., Kaufman, Y. J., Tanré, D., Mattoo, S., Chu, D. A., Martins, J. V., Li, R. R., Ichoku, C., Levy, R. C., Kleidman, R. G., Eck, T. F., Vermote, E., and Holben, B. N.: The MODIS aerosol algorithm, products and validation, J. Atmos. Sci., 62, 947-973, doi:10.1175/JAS3385.1, 2005.

Remer, L. A., Kleidman, R. G., Levy, R. C., Kaufman, Y. J., Tanré, D., Mattoo, S., Martins, J. V., Ichoku, C., Koren, I., Yu, H., and Holben, B. N.: Global aerosol climatology from the MODIS satellite sensors, J. Geophys. Res., 113, D14S07, doi:10.1029/2007JD009661, 2008.

Rodríguez, S., Querol, X., Alastuey, A., Kallos, G., and Kakaliagou, O.: Saharan dust contributions to $\mathrm{PM}_{10}$ and TSP levels in Southern and Eastern Spain, Atmos. Environ., 35, 2433-2447, doi:10.1016/S1352-2310(00)00496-9, 2001.

Salvador, P., Alonso-Pérez, S., Pey, J., Artíñano, B., de Bustos, J. J., Alastuey, A., and Querol, X.: African dust outbreaks over the western Mediterranean Basin: 11-year characterization of atmospheric circulation patterns and dust source areas, Atmos. Chem. Phys., 14, 6759-6775, doi:10.5194/acp-14-6759-2014, 2014.

Schepanski, K., Tegen, I., Todd, M. C., Heinold, B., Bönisch, G., Laurent, B., and Macke, A.: Meteorological processes forcing Saharan dust emission inferred from MSG-SEVIRI observations of subdaily dust source activation and numerical models, J. Geophys. Res., 114, D10201, doi:10.1029/2008jd010325, 2009.

Schuster, G. L., Vaughan, M., MacDonnell, D., Su, W., Winker, D., Dubovik, O., Lapyonok, T., and Trepte, C.: Comparison of CALIPSO aerosol optical depth retrievals to AERONET measurements, and a climatology for the lidar ratio of dust, Atmos. Chem. Phys., 12, 7431-7452, doi:10.5194/acp-12-7431-2012, 2012.

Sicard, M., Bertolín, S., Mallet, M., Dubuisson, P., and Comerón, A.: Estimation of mineral dust long-wave radiative forcing: sensitivity study to particle properties and application to real cases in the region of Barcelona, Atmos. Chem. Phys., 14, 9213-9231, doi:10.5194/acp-14-9213-2014, 2014

Smirnov, A., Holben, B. N., Eck, T. F., Dubovik, O., and Slutsker, I.: Cloud screening and quality control algorithms for the
AERONET database, Remote Sens. Environ., 73, 337-349, doi:10.1016/S0034-4257(00)00109-7, 2000.

Solmon, F., Mallet, M., Elguindi, N., Giorgi, F., Zakey, A., and Konaré, A.: Dust aerosol impact on regional precipitation over western Africa, mechanisms and sensitivity to absorption properties, Geophys. Res. Lett., 35, L24705, doi:10.1029/2008GL035900, 2008.

Stephens, G. L., Vane, D. G., Boain, R. J., Mace, G. G., Sassen, K., Wang, Z., Illingworth, A. J., O'Conner, E. J., Rossow, W. G., Durden, S. L., Miller, S. D., Austin, R. T., Benedetti, A., and Mitrescu, C.: The CloudSat mission and the A-Train, B. Am. Meteorol. Soc., 83, 1771-1790, doi:10.1175/BAMS-83-121771, 2002.

Tafuro, A. M., Barnaba, F., De Tomassi, F., Perrone, M. R., and Gobbi, G. P.: Saharan dust particle properties over the Central Mediterranean, Atmos. Res., 81, 67-93, doi:10.1016/j.atmosres.2005.11.008, 2006.

Tanré, D., Kaufman, Y. J., Herman, M., and Mattoo, S.: Remote sensing of aerosol properties over oceans using the MODIS/EOS spectral radiances, J. Geophys. Res., 102, 1697116988, doi:10.1029/96JD03437, 1997.

Tegen, I.: Modelling the mineral dust aerosol cycle in the climate system, Quaternary Sci. Rev., 22, 1821-1834, doi:10.1016/S0277-3791(03)00163-X, 2003.

Toledano, C., Cachorro, V. E., de Frutos, A. M. Sorribas, M., Prats, N., and de la Morena, B. A.: Inventory of African desert dust events over the southwestern Iberian Peninsula in 2000-2005 with an AERONET Cimel Sun Photometer, J. Geophys. Res., 112, D21201, doi:10.1029/2006JD008307, 2007a.

Toledano, C., Cachorro, V. E., Sorribas, M., Berjón, A., de la Morena, B. A., de Frutos, A. M., and Gouloub, P.: Aerosol optical depth and Ångström exponent climatology at El Arenosillo AERONET site (Huelva, Spain), Q. J. Roy. Meteor. Soc., 133, 795-807, doi:10.1002/qj.54, 2007b.

TOMS Science Team: TOMS/Earth-Probe Total Ozone Aerosol Index UV-Reflectivity UV-B Erythemal Irradiance Daily L3 Global 1x1.25 deg, version 008, Greenbelt, MD, NASA Goddard Space Flight Center, available at: http://disc.sci. gsfc.nasa.gov/datacollection/TOMSEPL3_V008.html, last access: 26 May 2016.

Torres, O., Bhartia, P. K., Herman, J. R., Ahmad, Z. and Gleason, J.: Derivation of aerosol properties from a satellite measurements of backscattered ultraviolet radiation: Theoretical basis, J. Geophys. Res., 103, 17099-17110, doi:10.1029/98JD00900, 1998.

Torres, O., Bhartia, P. K., Herman, J. R., Sinyuk, A., and Holben, B.: A long term record of aerosol optical thickness from TOMS observations and comparison to AERONET measurements, J. Atmos. Sci., 59, 398-413, doi:10.1175/15200469(2002)059<0398:ALTROA>2.0.CO;2, 2002.

Torres, O., Bhartia, P. K., Sinyuk, A., Welton, E. J., and Holben, D.: Total Ozone Mapping Spectrometer measurements of aerosol absorption from space: Comparison to SAFARI 2000 ground-based observations, J. Geophys. Res., 110, D10S18, doi:10.1029/2004JD004611, 2005.

Torres, O., Tanskanen, A., Veihelman, B., Ahn, C., Braak, R., Bhartia, P. K., Veefkind, P., and Levelt, P.: Aerosols and Surface UV Products from OMI Observations: An Overview, J. Geophys. Res., 112, D24S47, doi:10.1029/2007JD008809, 2007. 
Trigo, I. F., Bigg, G. R., and Davies, T. D.: Climatology of cyclogenesis in the Mediterranean, Mon. Weather Rev., 130, 549-569, doi:10.1175/1520-0493(2002)130<0549:COCMIT>2.0.CO;2, 2002.

Tsamalis, C., Chédin, A., Pelon, J., and Capelle, V.: The seasonal vertical distribution of the Saharan Air Layer and its modulation by the wind, Atmos. Chem. Phys., 13, 11235-11257, doi:10.5194/acp-13-11235-2013, 2013.

Varga, G., Ùjvári, G., and Kovács, J.: Spatiotemporal patterns of Saharan dust outbreaks in the Mediterranean Basin, Aeolian Res., 15, 151-160, doi:10.1016/j.aeolia.2014.06.005, 2014.

Vaughan, M. A., Powell, K. A., Kuehn, R. E., Young, S. A., Winker, D. M., Hostetler, C. A., Hunt, W. H., Liu, Z. Y., McGill, M. J., and Getzewich, B. J.: Fully automated detection of cloud and aerosol layers in the CALIPSO lidar measurements, J. Atmos. Ocean. Tech., 26, 2034-2050, doi:10.1175/2009jtecha1228.1, 2009.

Winker, D., Vaughan, M., Omar, A., Hu, Y., Powell, K., Liu, Z., Hunt, W., and Young, S.: Overview of the CALIPSO mission and CALIOP data processing algorithm, J. Atmos. Ocean. Technol., 26, 2310-2323, doi:10.1175/2009JTECHA1281.1, 2009.
Winker, D. M., Tackett, J. L., Getzewich, B. J., Liu, Z., Vaughan, M. A., and Rogers, R. R.: The global 3-D distribution of tropospheric aerosols as characterized by CALIOP, Atmos. Chem. Phys., 13, 3345-3361, doi:10.5194/acp-13-3345-2013, 2013.

Yoon, J., von Hoyningen-Huene, W., Kokhanovsky, A. A., Vountas, M., and Burrows, J. P.: Trend analysis of aerosol optical thickness and Ångström exponent derived from the global AERONET spectral observations, Atmos. Meas. Tech., 5, 12711299, doi:10.5194/amt-5-1271-2012, 2012.

Zhang, J. L., Reid, J. S., and Holben, B. N.: An analysis of potential cloud artifacts in MODIS over ocean aerosol optical thickness products, Geophys. Res. Lett., 32, L15803, doi:10.1029/2005GL023254, 2005.

Zhang, L., Li, Q. B., Gu, Y., Liou, K. N., and Meland, B.: Dust vertical profile impact on global radiative forcing estimation using a coupled chemical-transport-radiative-transfer model, Atmos. Chem. Phys., 13, 7097-7114, doi:10.5194/acp-13-70972013, 2013. 